\title{
SEGMENTAÇÃO DE IMAGENS MAMOGRÁFICAS PARA DETECÇÃO DE NÓDULOS EM MAMAS DENSAS
}

\section{Vivian Toledo Santos}

Dissertação apresentada à Escola de Engenharia de São Carlos, da Universidade De São Paulo, como requisito para obtenção do Título de Mestre em Engenharia Elétrica.

Orientador: Prof. Associado HOMERO SCHIABEL

São Carlos

Novembro - 2002 
Dedico...

Dedico este trabalho a minha família.

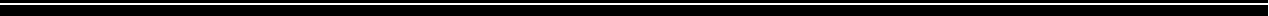




\section{Agradecimentos} pessoas.

A DEUS, pela minha vida e pela oportunidade de conhecer todas estas

Ao Prof. Dr. Homero Schiabel, pela orientação, incentivo, apoio e confiança em meu trabalho.

Aos meus pais por serem meus alicerces, grandes incentivadores e por sempre terem me dado opções de escolha. Minha mãe e melhor amiga, pelo apoio em todos os momentos, pela força quando por qualquer motivo me sentia fraca e por sempre acreditar em todos os meus projetos. Meu pai, pelos conselhos, pela presença diária em minha vida, mesmo que um pouco distante, por ser meu "guru" em tomadas de decisões importantes.

A minha irmãzinha...meu braço direito, por tomar conta de tudo, inclusive, cuidar de mim. Obrigada, Carol.

Ao vovô Samuel e vovó Vivi por estarem sempre cuidando da nossa família, por serem os amores da minha vida e pela educação que me deram, devo muito a vocês.

Ao vô Mario e vó Nide, pelo carinho que sempre me deram nos momentos em que pudemos estar juntos.

Ao meu namorado, Rogério, pelo amor, compreensão, ajuda em momentos difíceis e por compartilhar comigo as alegrias pelas etapas vencidas.

A minha grande amiga Ana Cláudia por me mostrar o que é amizade verdadeira e por ser companheira em todas as horas. Devo muito a você, Ana, se hoje estou aqui foi porque você foi a primeira a acreditar e confiar em mim.

A Fátima, pelas viagens, apoio, incentivo e orientação. Por mostrar ser realmente uma educadora e principalmente uma mulher de fibra.

A minha amiga Helien pelas conversas, apoio e por muitos momentos agradáveis que passamos em casa.

Ao Marcelo, pela amizade, por me ouvir, pelos conselhos e por me fazer ver as coisas de um jeito diferente.

Ao meu amigo César, pela disponibilidade, confiança e sinceridade. Sua amizade é realmente importante pra mim.

Ao Rodrigo, pela amizade, prestatividade e pela ajuda no trabalho nas horas que mais precisei. Obrigada mesmo!

A Ana Claudia (LADI), pela sinceridade, disposição, pelo agradável convívio no laboratório, pela companhia nos Congressos e também por todos os momentos de descontração e hiper-atividade. trabalho.

Ao Maurício pelo companheirismo e ajuda durante o desenvolvimento deste

Ao Cláudio, por toda ajuda e companhia nas viagens.

A Michele, pela amizade e por sempre me incluir na sua lista na hora de enviar e-mails.

A Kathy, Kátia e Fábio pelo coleguismo, pelas horas de descontração.

Aos amigos do Byte Café por compreenderem minha ausência em vários momentos e principalmente ao Jonas, pela amizade e por se preocupar com o bom funcionamento da loja.

Aos meus amigos de São Carlos: Silvio, Rogério, Almir, Cássio e Thiago.

Aos funcionários do departamento, pela ajuda quando necessária.

Aos meus amigos e professores da FATEC.

A CAPES pelo apoio financeiro. 


\section{Sumário}

Resumo___-_-_-_-_-_-_-_-_-_-_-_-_-_-_-_-_-_-_-_-_-_-_-_-_-_-_ 1

Abstrac _-_-_-_-_-_-_-_-_-_-_-_-_-_-_-_-_-_-_-_-_-_-_-_-_-_-_-_-_-_-_-_ 2

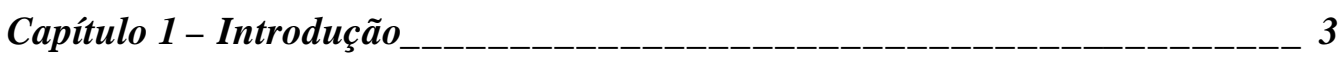

1.1 O Câncer de Mama_________________________________________ 3

1.2 O Processamento de Imagens: Ferramenta de Auxílio ao Diagnóstico 7

1.3 Objetivos ___________________________________________________ 9

Capítulo 2 - Mamas Densas e Nódulos __-__-__-__-__-__-_-_-_-__-_ 11

2.1 Estruturas da Mama __________________________________________ 12

2.2 Nódulos _____________________________________________________ 13

2.3 A Densidade da Mama _____________________________________ 18

2.4 Classificação da Mama Segundo a Densidade__________________ 24

2.5 Fatores que Dificultam a Aquisição da Imagem da Mama________ 25

Capítulo 3 - Mamografia _-_-_-_-_-_-_-_-_-_-_-_-_-_-_-_-_-_-_-_-_-_ 27

3.1 O Equipamento Mamográfico_________________________________ 35

3.1.1 - Mamógrafo Digital_______________________________________ 38

3.2 O Exame Mamográfico_______________________________________ 39

3.3 Alcance e Limitação da Mamografia___________________________ 40

3.4 Indicações da Mamografia:________________________________ 41

3.5 Esquemas CAD (Computer-Aided Diagnosis) _________________ 41

3.6 Dificuldades Encontradas na Visualização de Estruturas no Mamograma 45

3.6.1 Dose Absorvida____________________________________________ 46

3.6.2 Sobreposição de Objetos _________________________________ 47

3.6.3 Contraste e Resolução Espacial ___________________________ 47

Capítulo 4 - Segmentação de Imagens_____________________________-_ 50

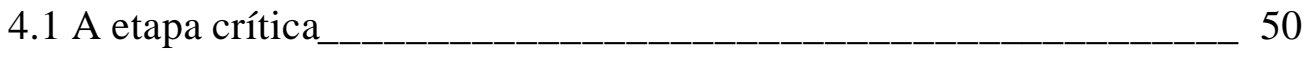

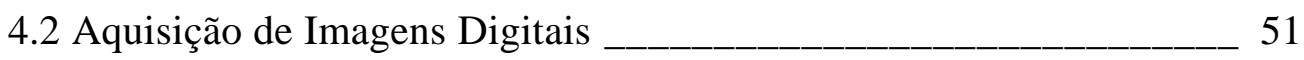

4.2.1 Sensores___-__-_-_-_-_-_-_-_-_-_-_-_-_-_-__-_-_-_-_-_-_-_ 51

4.2.2 Digitalização _-_-_-_-_-_-_-_-_-_-_-_-_-_-_-_-_-_-_-_-_-_-_-_ 52

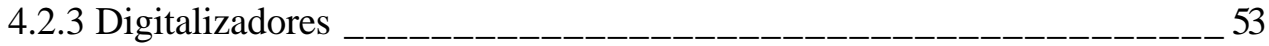

4.3 Técnicas de Segmentação de Imagens_________________________ 54

4.3.1 Limiarização - A Intensidade Como Separador 
4.3.2 Métodos Baseados nos Contornos dos Objetos 55

4.3.3 Crescimento de Regiões

4.3.4 Morfologia Matemática

4.4 Segmentação Usando o Algoritmo Watershed 59

4.4.1 O Gradiente Morfológico 60

4.4.2 A Transformada da Distância: 62

4.4.3 Análise dos Pontos de Mínimo e Máximo 66

4.4.4 Algoritmo Clássico de Imersão 68

Capítulo 5-Materiais e Métodos 71

5.1 Pré-Processamento das Imagens 72

5.2 O Algoritmo 75

5.3 Pós-Processamento: Corrigindo Defeitos da Segmentação 5.3.1 Rotulação 79

5.4 Problemas Encontrados 79

6 Resultados 83

7 Discussões e Conclusões 84

7.1 Desempenho do Sistema Desenvolvido 96

7.2 Conclusões 97

7.3 Sugestões para Trabalhos Futuros 100 Referências Bibliográficas 101 103 


\section{Lista de Figuras}

Figura 2-1-Densidade da mama. (INCA, 2002).

Figura 2-2 - Imagens de mamogramas reais com diferentes densidades. (a) mamograma de uma mama considerada densa-mulher com 21 anos de idade; (b) mamograma de uma mama considerada não densa-mulher com 67 anos de idade.

Figura 2-3 - Glândulas do Tecido Mamário [Fonte: http://www.inca.org.br]__ 12

Figura 2-4 - Esquema da densidade assimétrica na projeção dos quadrantes inferiores da mama esquerda (Fonte:

http://www.hps.com.br/medicinanuclear/mamoalta.htm).

Figura 2-5 Incidência MLD, demonstra 2 lesões nodulares de bordas espiculadas. A maior em região retro-areolar determinando retração do complexo aréolopapilar. A menor localizada junto ao prolongamento axilar.

Figura 2-6 Incidência de magnificação da mama direita: Nódulo de contorno lobulado e limites parcialmente definidos com microcalcificações pleomórficas no seu interior (Lesão com Alto Índice de Suspeição Mamográfica).

Figura 2-7 Incidência MLD: Nódulo de contorno lobulado e limites bem definidos, com calcificações grosseiras no seu interior. (Fibroadenoma)

Figura 2-8 Incidência focada em CCE: Pequeno nódulo de limites parcialmente definidos em região retro areolar.

Figura 2-9 Incidência em magnificação CCD: Pequeno nódulo de contorno regular e limites precisos localizados na projeção dos quadrantes internos.

Figura 3-1 - Incidência Médio-lateral (ML) das mamas, em um exame normal de boa qualidade técnica. 28

Figura 3-2 - Incidência Crânio Caudal (CC) das mamas, em um exame normal de boa qualidade técnica. 29

Figura 3-3 - Compressão da mama para realização da mamografia com a Incidência Crânio Caudal (CC). 29

Figura 3-4 Ilustração de um mamógrafo (Fonte: http://www.uspar.com.br). 35

Figura 3-5 Esquema de um aparelho mamográfico durante a realização do exame (Wolbarst,1993). 37

Figura 3-6. Esquema simplificado de um aparelho de mamografia digital. 38

Figura 4-1 - Segmentação de imagem utilizando a técnica de crescimento de regiões. (Gonzalez,1992) (a) Imagem original mostrando um ponto semente; (b) estágio primário de crescimento de região; (c) estágio intermediário de crescimento de região; (d) região final 58

Figura 4-2 - Ilustração da topografia com os pontos de mínimo. 
Figura 4-3 - Exemplo de imagem original, imagem dilatada, erodida e o gradiente

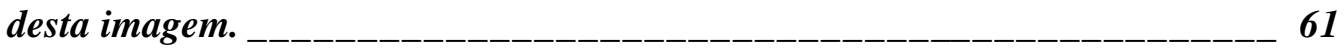

Figura 4-4 - Elemento estruturante com três estados ___________________ 62

Figura 4-5 - elementos estruturantes utilizados para detecção de vértices ___- 62

Figura 4-6 - detecção dos vértices de um objeto utilizando thining _-__-___- 63

Figura 4-7 - definição informal de esqueleto (fontes de fogo ao longo da fronteira do objeto)

Figura 4-8 - definição formal de esqueleto através do conceito de bolas maximais

Figura 4-9 - Determinação do Skiz de uma imagem 66

Figura 4-10 (a) Imagem original de grãos; (b) Imagem dos Marcador es; (c) Imagem Segmentada por Watershed; (d) Imagem Dilatada; (e) Imagem Erodida; (f) Imagem Final. (MARQUES; VIEIRA-1992)

Figura 4-11: Ilustração do algoritmo de imersão. (a) imagem original; (b-e) passos de rotulação.

Figura 5-1 Exemplo de equalização de histograma. São mostradas as imagens original e processada e seus respectivos histogramas. 73

Figura 5-2 Exemplo de imagem original. 75

Figura 5-3 Imagem original e marcadores da imagem.__________________ 76

Figura 5-4 Imagem original, marcadores e zonas de influência. 77

Figura 5-5 Imagem com as linhas de Watershed e junção com a imagem original. 78

Figura 5-6 Imagem segmentada e o seu contorno. 78

Figura 5-7 Imagem original e contorno sobre a imagem. 79

Figura 5-8 - Operação de rotulação (labeling) Imagem original e Conectividade 8 80

Figura5 -9 - Conceitos de 4-vizinhança, vizinhança diagonal e 8 -vizinhança _- 80

Figura 5-10 - Diagrama de Blocos representando o Sistema Desenvolvido 82

Figura 6-10 - Diagrama de Blocos representando o Sistema Desenvolvido 84

Figura 6-2 (a) Imagem Original; (b) Imagem Segmentada somente com Watershed; (c) Imagem Equalizada; (d) Imagem Segmentada com a combinação de ambas as técnicas e apresentação de ruídos; (e) Imagem final após rotulação. 87 Figura 6-3 (a) Imagem Original; (b) Imagem Segmentada somente com Watershed; (c) Imagem Equalizada; (d) Imagem Segmentada com a combinação de ambas as técnicas e apresentação de ruídos; (e) Imagem final após rotulação. 88 
Figura 6-4 (a) Imagem Original; (b) Imagem Segmentada somente com Watershed; (c) Imagem Equalizada; (d) Imagem Segmentada com a combinação de ambas as técnicas e apresentaçã o de ruídos; (e) Imagem final após rotulação. 89

Figura 6-5 (a) Imagem Original; (b) Imagem Segmentada somente com Watershed; (c) Imagem Equalizada; (d) Imagem Segmentada com a combinação de a mbas as técnicas e apresentação de ruídos; (e) Imagem final após rotulação. 90

Figura 6-6 (a) Imagem Original; (b) Imagem Segmentada somente com Watershed; (c) Imagem Equalizada; (d) Imagem Segmentada com a combinação de ambas as técnicas e apresentação de ruídos; (e) Imagem final após rotulação. 91

Figura 6-7 (a) Imagem Original; (b) Imagem Segmentada somente com Watershed, indicando um falso-negativo; (c) Imagem Equalizada; (d) Imagem Segmentada com a combinação de ambas as técnicas e apresentação de ruídos; (e) Imagem final após rotulação. 92

Figura 6-8 (a) Imagem Original; (b) Imagem Segmentada somente com Watershed; (c) Imagem Equalizada; (d) Imagem Segmentada com a combinação de ambas as técnicas e apresentação de ruídos; (e) Imagem final após rotulação. 93

Figura 6-9 (a) Imagem Original; (b) Imagem Segmentada somente com Watershed; (c) Imagem Equalizada; (d) Imagem Segmentada com a combinação de ambas as técnicas e apresentação de ruídos; (e) Imagem final após rotulação. 94

Figura 6-10 (a) Imagem Original; (b) Imagem Segmentada somente com Watershed, não apresentando detecção; (c) Imagem Equalizada; (d) Imagem Segmentada com a combinação de ambas as técnicas não apresentando detecção, sendo um falso-negativo. 95

Figura 7-1 Curva ROC das Imagens Processadas 99 


\section{Lista de Tabelas}

Tabela 2-1 - Densidade parenquimal em mamogramas de mulheres de 25 a 79 anos (Stomper et al., 1996).

Tabela 2-2 - Distribuição de casos de acordo com a densidade mamográfica e o risco de desenvolvimento de câncer (Boyd et al., 1995). 23

Tabela 4-1 - Exemplificação da matriz de pixels de uma imagem. 52

Tabela 6-1 - Resultados obtidos com o processamento das imagens 85

Tabela 6-2 - Resultados VP e taxa de ruído 85

Tabela 6-3 - Taxas de acertos e erros obtidos com o processamento das imagens.86

Tabela 7-1 - Resultados obtidos com o processamento das imagens 98 


\section{Resumo}

O presente trabalho de pesquisa trata da implementação de um esquema de processamento para detectar nódulos em mamas densas em imagens mamográficas digitalizadas, com base na técnica da Transformada Watershed. Esse sistema é parte integrante de um esquema computadorizado para auxílio ao diagnóstico em mamografia, que utiliza técnicas de processamento de imagens digitais para identificar, realçar e classificar estruturas de interesse clínico. Utilizaram-se também técnicas de pré e pósprocessamentos (equalização do histograma e rotulação) para que as imagens pudessem ser mais bem analisadas. Os resultados mostraram que as técnicas implementadas, se combinadas, detectam aproximadamente $93 \%$ dos nódulos existentes no grupo das imagens analisadas. 


\begin{abstract}
Abstrac
This research corresponds to the implementation of a computational processing scheme aimed to detect nodules in dense breast digitized images, based on Watershed Transformation technique. It is part of a computer-aided diagnosis scheme in mammography, which uses digital image processing techniques to identify, to enhance and to classify structures of clinical interest. Also pre and pos-processing techniques (histogram equalization and labeling) were used to allow better images analysis. The results have shown that these proposed techniques, when combined, could detect about $93 \%$ of true nodules in the analyzed images set.
\end{abstract}




\section{Capítulo 1 - Introdução}

\subsection{Câncer de Mama}

Anualmente, cerca de um milhão de mulheres em todo o mundo descobre que está com câncer de mama, segundo a Organização Mundial de Saúde (OMS). No Brasil, a cada ano são diagnosticados, em média, 31.500 novos casos da doença, de acordo com o Instituto Nacional de Câncer (INCA).

As células dos diversos órgãos do nosso corpo estão cons tantemente se reproduzindo, isto é, uma célula adulta divide-se em duas, e por este processo, chamado mitose, há o crescimento e a renovação das células durante os anos. A mitose é realizada controladamente dentro das necessidades do organismo. Porém, em determinadas ocasiões e por razões ainda desconhecidas, certas células reproduzem-se com uma velocidade maior, desencadeando o aparecimento de massas celulares denominadas neoplasias.

Nas neoplasias malignas o crescimento é mais rápido, desordenado e infiltrativo; as células não guardam semelhança com as que Ihes deram origem e têm capacidade de se desenvolver em outras partes do corpo, fenômeno este denominado metástase, que é a característica principal dos tumores malignos.

Segundo o INCA (Instituto Nacional de Câncer), o câncer de mama é o câncer mais comum nas mulheres e o maior causador de mortes nessa população (INCA, 2002), apresentando-se, geralmente, como um nódulo na mama. As primeiras metástases comumente aparecem nos gânglios linfáticos das axilas.

No Brasil, segundo o INCA, entre as mulheres, o câncer de mama ocupa o primeiro lugar em incidência nas regiões Nordeste, Sul e Sudeste, 
sendo responsável respectivamente, por 22,84\%, 24,14\% e 23,83\% dos novos diagnósticos de neoplasia em mulheres. Em 1998, foram registradas 8.044 mortes decorrentes deste tipo de câncer. Dos 337.535 novos casos de câncer com previsão de serem diagnosticados em 2002, o câncer de mama será o principal a atingir a população feminina, sendo responsável por 36.090 novos casos (INCA, 2002).

O câncer mamário mínimo é definido como um câncer com menos de $0,5 \mathrm{~cm}$ de diâmetro, e pode-se referir a carcinoma lobular in situ, câncer intraductal e cânceres invasivos. Outros tumores que exibem um potencial clínico favorável, tais como o mucinoso, o colóide e o papilar, podem ser considerados como mínimos, e se apresentam como uma massa palpável lisa, que na mamografia e ao exame clínico pode parecer benigna. A maioria dos cânceres que são clinicamente palpáveis medem $1 \mathrm{~cm}$ ou mais de tamanho. Mesmo os cânceres mamários mínimos de $0,5 \mathrm{~cm}$, tidos como clinicamente iniciais, representam um tumor biologicamente tardio. $O$ tamanho médio dos cânceres detectados por auto -exame é maior do que $2 \mathrm{~cm}$ (Bauer, 1980).

O câncer de mama, no entanto, comporta-se menos previsivelmente do que outros cânceres, e embora algumas pacientes com doença não tratada possam sobreviver por longos períodos, outras pacientes com câncer mínimo de mama podem sucumbir muito rapidamente. Os aspectos importantes na predição da gravidade do câncer de mama incluem a magnitude da resposta do hospedeiro e as características do tumor. A sobrevida das pacientes é diretamente relacionada com o tamanho do tumor no diagnóstico inicial e com a presença ou ausência de linfonodos axilares positivos. Portanto, o diagnóstico precoce não apenas influencia o prognóstico, mas propicia cirurgia cosmeticamente mais aceitável que pode fornecer índices livres de recidiva e de sobrevida comparáveis a intervenções cirúrgicas mais dramáticas e agressivas(Bauer, 1980).

Embora a maioria dos cânceres pareçam evoluir a partir de uma seqüência de alterações patológicas descritas como hiperplasia, hiperplasia atípica e carcinoma in situ, essa progressão não é obrigatória ou contínua. 
Entretanto, a forma proliferativa da doença fibrocística, caracterizada por hiperplasia ductal, papilomatose, epiteliose e papilomas múltiplos, representa uma forma de alteração pré-cancerosa, havendo evidência clara de que pelo menos a forma proliferativa de doença fibrocístca não é apenas um precursor do câncer de mama, mas uma das suas expressões morfológicas mais iniciais (Fisher, 1981). O diagnóstico precoce do câncer de mama seria incrementado se as técnicas pudessem detectar com precisão e de forma não invasiva estas alterações pré-cancerosas hiperplásicas.

As causas para o aparecimento do câncer na mama ainda não são totalmente conhecidas. Sabe-se que a combinação de mutações genéticas, estilo de vida e influência ambiental podem levar, sem uma razão específica, a mudanças no funcionamento dos genes das células mamárias. Pode-se passar a vida inteira com uma mutação genética sem, necessariamente, desenvolver um tumor. O problema é quando ela ocorre em duas categorias específicas de genes: nos oncogenes, que são os causadores de câncer, ou nos genes supressores de tumor, responsáveis por prevenir qualquer alteração no DNA e conter o crescimento celular descontrolado.

Algumas características favorecem o aparecimento de um tumor na mama. Existem estudos que indicam que o câncer de mama apresenta forte dependência hormonal e que o estrógeno, o hormônio sexual feminino, em grandes quantidades poderia ser tóxico para os genes, segundo a mastologista Carmen Molina Wolgien, pesquisadora da Universidade Federal de São Paulo (INCA, 2002). Por isso fazem parte do grupo de risco mulheres que estão sob uma exposição mais longa à ação do estrógeno: aquelas que tiveram sua primeira menstruação muito cedo e entram tardiamente na menopausa, as que engravidaram pela primeira vez depois dos 30 anos ou, ainda, as que chegam à meia-idade sem filhos. Complementando, o amadurecimento total das células mamárias só ocorre com as mudanças orgânicas trazidas pela gravidez e pela amamentação, segundo Maria Elisabeth de Mesquita, mastologista do Hospital das Clínicas de São Paulo (INCA, 2002). 
O estilo de vida também desempenha um papel importante. Alimentação com base em comidas gordurosas e carnes vermelhas e sedentarismo também propiciam o aparecimento do câncer. Mas as células malignas não escolhem este ou aquele organismo para aparecer e se alastrar. Uma das explicações para isso seria a herança familiar: genes modificados que passam de pais para filhos. Entre 5\% e 10\% dos casos são hereditários. Apesar de ser considerado uma doença tipicamente feminina, o câncer de mama atinge cerca de $1 \%$ de todos os homens do planeta. Outros tantos, mesmo sem apresentar a doença, são portadores de mutações nos genes que levam ao câncer e podem passá-los aos filhos e filhas (INCA, 2002).

Existe um consenso entre os especialistas de que a mulher não morre de câncer de mama, mas com câncer de mama. A causa da morte é a metástase que leva a doença aos órgãos vitais, como o fígado, o pulmão, a coluna e o cérebro. Como a mama é uma região muito vascularizada, as células malignas podem seguir pelos vasos sanguíneos ou linfáticos para outras partes do corpo. Se o tumor for identificado precocemente, as chances de essas células malignas se espalharem diminui.

Cerca de $80 \%$ dos tumores de mama são descobertos pela própria mulher, palpando suas mamas incidentalmente. Quando isto ocorre, eles já apresentam um tamanho grande, o que dificulta o tratamento. O que se pretende é a descoberta desses tumores de tamanho o menor possível (de 1 a $3 \mathrm{~cm}$ ), de maneira que a doença seja tratada ainda em fase inicial. Os recursos terapêuticos são, então, mais eficazes, permitindo tratamentos menos mutiladores e com maior probabilidade de controle (INCA, 2002).

Os conhecimentos que hoje se têm sobre o câncer de mama são insuficientes para a adoção de programas de prevenção primária, ou seja, medidas que evitem o aparecimento da doença. A maioria dos esforços relacionados ao controle dessa doença está dirigida às ações de detecção precoce, isto é, à descoberta dos tumores ainda pequenos, comconseqüente tratamento na fase inicial da doença. Portanto, é muito importante para o 
diagnóstico da doença, o exame das mamas feito mensalmente pela própria mulher, e o feito pelo médico no decurso de uma consulta, de rotina ou não.

Infelizmente ainda não se dispõe de prevenção com eficácia comprovada, e o melhor que podemos fazer é a detecção precoce através da mamografia de alta resolução. A detecção precoce do câncer conduz a melhorias significativas no tratamento. A OMS divulgou, no início de 2002, um comunicado atestando que a mamografia realmente pode ter prevenido $35 \%$ dos casos de morte por câncer de mama em mulheres entre 50 e 69 anos.

Um aspecto relevante a se destacar é em relação à composição do tecido mamário, que exerce influência na nitidez da imagem mamográfica. As mulheres mais jovens apresentam mamas com maior quantidade de tecido glandular, o que torna esses órgãos mais densos e firmes. Ao se aproximar da menopausa, o tecido mamário vai-se atrofiando e sendo substituído progressivamente por tecido gorduroso, até se constituir, quase que exclusivamente, de gordura e resquícios de tecido glandular na fase pósmenopausa. Essas mudanças de características promovem uma nítida diferença entre as densidades radiológicas das mamas da mulher joveme da mulher na pós-menopausa. No entanto, com o advento da reposição hormonal, vemos que essa substituição de tecidos não ocorre, acarretando mamas densas mesmo em mulheres idosas.

\subsection{O Processamento de Imagens: Ferramenta de Auxílio ao Diagnóstico}

Atualmente o uso de imagens médicas vem adquirindo uma importância ímpar para o diagnóstico e auxílio na intervenção médica. O tempo despendido para trabalhar com essas imagens, a subjetividade dos atributos extraídos, e a necessidade contínua de investigação para o progresso na área, têm feito surgir novas técnicas auxiliares no trato das imagens. 
Entre as diversas áreas de estudo reunidas sob o denominador comum de processamento digital de imagens, encontramos a área conhecida como análise de imagens. Este campo de estudos visa ao desenvolvimento de técnicas que permitam extrair informações das imagens, possibilitando às pessoas e às máquinas maior poder de análise, resultando em maior suporte ao diagnóstico.

A incorporação de técnicas computacionais para análise dessas imagens representa uma segunda revolução nesta área. O principal fator do sucesso e da crescente disseminação de abordagens de diagnóstico clínico e pesquisas baseadas em imagens é o desenvolvimento de métodos computacionais sofisticados para extração e análise de informações cientificamente importantes e clinicamente relevantes a partir da imagem original.

Neste contexto, uma das principais etapas é a segmentação de estruturas de interesse em uma imagem médica. Segmentação de imagens refere-se ao processo de dividir a imagem em diversas partes elementares (segmentos), permitindo a análise destas partes isoladamente. 0 procedimento de segmentar a imagem possibilita a utilização de um modelo matemático/geométrico na descrição, análise e clas sificação das estruturas. Este processo tem várias etapas bem definidas que vão desde o realce de estruturas até a identificação propriamente dita da imagem. A partir daí, a imagem resultante pode ser usada para outras tarefas, como a extração de formas e outras características, importantes em um processo de classificação. Para realizar esta tarefa é de extrema relevância um prévio conhecimento a respeito da imagem em questão.

Esquemas de diagnóstico auxiliado por computador têm sido propostos com o objetivo de auxiliar o radiologista no diagnóstico, indicando áreas suspeitas, bem como anormalidades mascaradas (Astley, 1990). Estes esquemas (CAD, de "computer-aided diagnosis") têm sido desenvolvidos por vários grupos de pesquisas, visando auxiliar na detecção precoce do câncer de mama. Giger (2000) define o diagnóstico auxiliado por computador como 
aquele no qual 0 radiologista usa os resultados de uma análise computadorizada de imagens médicas como uma "segunda opinião" na detecção de lesões e na elaboração do diagnóstico. A importância desses esquemas é enfatizada por Chan et al. (1990), Doi et al. (1991), Giger;MacMahon (1996) e Petrick et al. (1996b), mostrando que o uso de esquemas CAD pode melhorar o desempenho de radiologistas no diagnóstico médico.

Os esquemas CAD têm representado uma importante ferramenta no auxílio ao diagnóstico médico em diversas aplicações radiológicas, sobretudo na mamografia, a ponto de ter sido aprovado recentemente como recurso diagnóstico do câncer de mama pela FDA (Food and Drug Administration) nos EUA.

\subsection{Objetivos}

Com base nessas considerações preliminares, e dentro de um projeto maior em desenvolvimento pelo grupo do Laboratório de Digitalização de Imagens (LADI), na elaboração de um esquema CAD em mamografia, uma etapa importante é a segmentação dos mamogramas digitalizados com vista à detecção de massas suspeitas. Isso é tanto mais problemático quando a imagem-alvo corresponde a mamas de alta densidade, em que tais estruturas são freqüentemente "mascaradas" pela grande quantidade de tecidos fibroglandulares que as envolvem.

Por isso, neste trabalho apresentamos o desenvolvimento de etapas do processamento dos mamogramas para detecção de nódulos em mamas densas. Este processo tem várias etapas bem definidas. Primeiramente a imagem é pré-processada utilizando um programa que recorta a mama, separando-a do restante da imagem, reduzindo o tempo de processamento. Em seguida, utiliza-se a técnica de equalização do histograma da imagem de maneira a realçar o contraste entre as estruturas, preparando-a para a etapa de segmentação. 
Sendo assim, o objetivo deste trabalho é implementar uma técnica de segmentação baseada em morfologia matemática para detecção de nódulos em mamas densas, dando subsídios para o processo de classificação, envolvendo o cálculo de características geométricas como área, volume, forma entre outras.

Assim, o trabalho está composto de mais 7 capítulos, conforme descrição sumária abaixo:

Capítulo 2 - Informações sobre a estrutura da mama, a diferença de uma mama densa e uma liposubstituída e como ocorrem as doenças das mamas, com o intuito de esclarecer e exemplificar as características das imagens e estruturas a serem processadas.

Capítulo 3 - Abordagem das características do exame mamográfico, a importânca do exame para a detecção precoce do câncer de mama, a diferença de um mamógrafo convencional para um digital e também um item contendo alguns esquemas CAD para detecção de nódulos em mamas e outros órgãos.

Capítulo 4 - Um breve histórico sobre a segmentação de imagens, apresentação de algumas técnicas utilizadas e principalmente da transformada Watershed, falando sobre suas características, etapas de processamento, alguns exemplos de algoritmos utilizados e aplicação em diversos tipos de imagens.

Capítulo 5 - Descrição da metodologia utilizada para a implementação e desenvolvimento do sistema, utilizando a transformada Watershed para a segmentação de nódulos, bem como as técnicas utilizadas no pré e pósprocessamento.

Capítulo 6 - Resultados e análise das técnicas e do sistema implementado.

Capítulo 7 - Discussão sobre os resultados, principalmente com base em análise de curvas $R O C$, e conclusões finais.

Capítulo 8 - Referências Bibliográficas 


\section{Capítulo 2 - Mamas Densas e Nódulos}

As mudanças de características entre mamas jovens e pós-menopausa em termos das densidades radiológicas podem ser ilustradas pelas imagens mostradas nas Figuras 2-1 e 2-2.

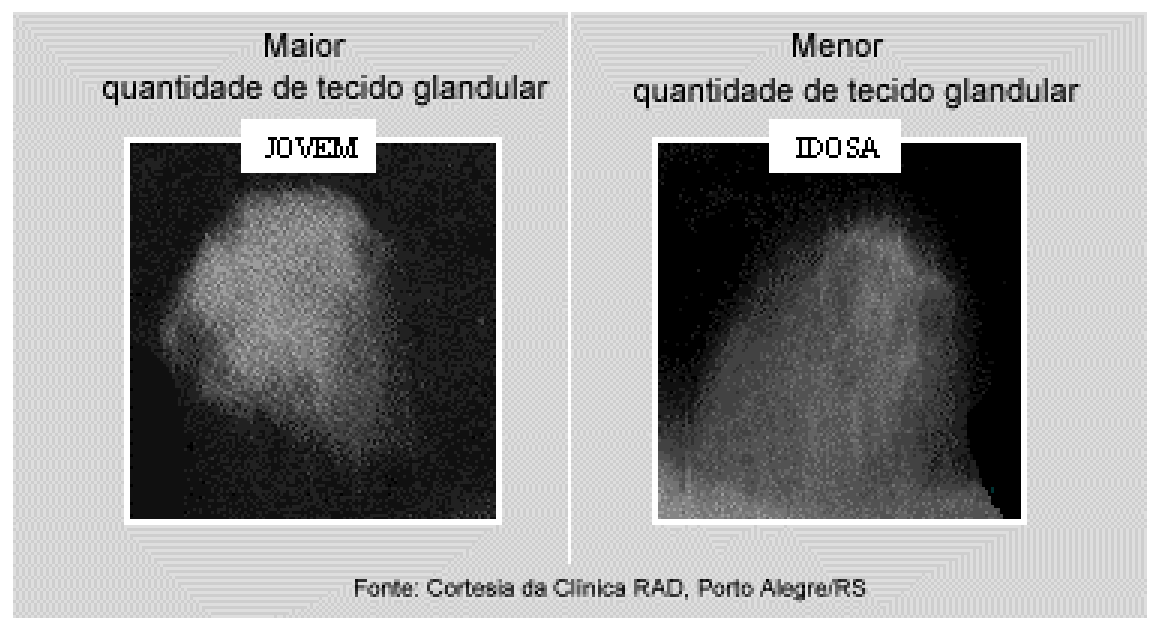

Figura 2-1- Densidade da mama. (INCA, 2002).

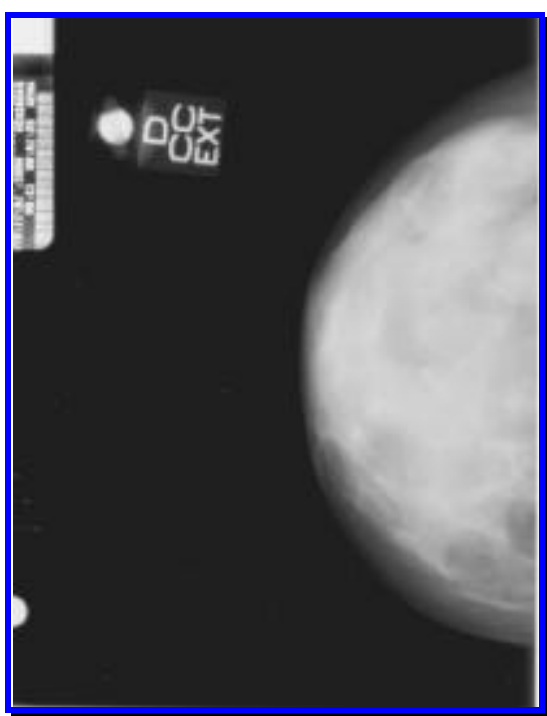

(a)

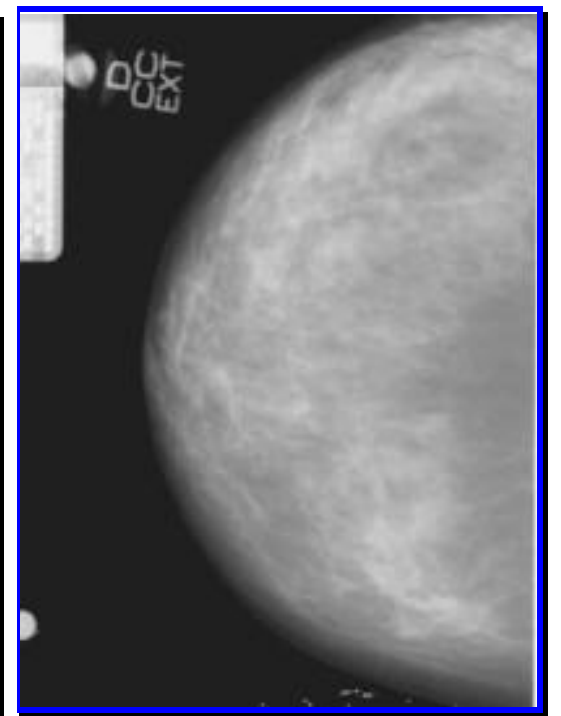

(b)

Figura 2-2 - Imagens de mamogramas reais com diferentes densidades. (a) mamograma de uma mama considerada densa-mulher com 21 anos de idade; (b) mamograma de uma mama considerada não densa-mulher com 67 anos de idade. 


\subsection{Estruturas da Mama}

As glândulas mamárias (Figura 2-3), que têm como principal função a secreção do leite, estão situadas na parede anterior do tórax e se compõem de:

$\Rightarrow$ Ácino - menor parte da glândula e responsável pela produção do leite durante a lactação;

$\Rightarrow$ Lóbulo mamário - conjunto de ácinos;

$\Rightarrow$ Lobo mamário - conjunto de lóbulos mamários que se liga à papila através de um ducto;

$\Rightarrow$ Ductos mamários - em número de 15 a 20 canais, conduzem a secreção (leite) até a papila;

$\Rightarrow$ Tecido glandular - conjunto de lobos e ductos;

$\Rightarrow$ Papila - protuberância elástica onde desembocam os ductos mamários;

$\Rightarrow$ Aréola - estrutura central da mama onde se projeta a papila;

$\Rightarrow$ Tecido adiposo - todo o restante da mama é preenchido por tecido adiposo ou gorduroso, cuja quantidade varia com as características físicas, es tado nutricional e idade da mulher.

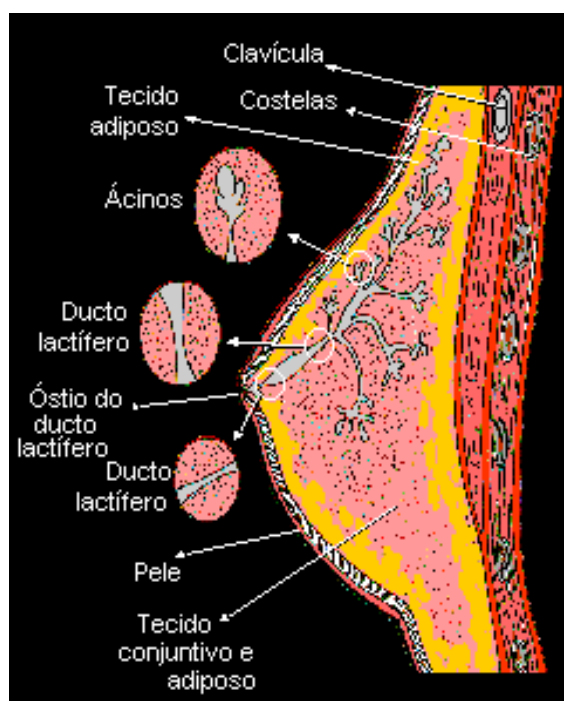

Figura 2-3 - Glândulas do Tecido Mamário [Fonte: http://www.inca.org.br] 


\subsection{Nódulos}

O mais antigo registro de câncer de mama da história médica vem do antigo Egito. Além de gravarem ou pintarem hieróglifos na pedra, os egípcios gravavam sua escrita cursiva em delgadas folhas de papiro. Entre seis papiros principais, o mais informativo a respeito das doenças da mama é o encontrado por Edwing Smith (1822-1906) em Tebas (atualmente Luxor e Karnak) em 1862. Datando de cerca de 1600 A.C., ele constitui um rolo de cerca de 4,5 metros de comprimento, escrito em ambos os lados. A frente contém 17 colunas com 48 casos dedicados à clínica cirúrgica. São feitas referências a doenças da mama tais como abscessos, traumatismos e feridas infectadas. $\mathrm{O}$ caso é talvez o mais antigo registro de câncer de mama (Bland \& Copeland1994).

Segundo o INCA, o limite da normalidade no tecido mamário é difícil de ser definido devido às modificações dinâmicas verificadas nas mamas ao longo da vida das mulheres. Daí surgiu o conceito de alterações funcionais benignas da mama, antigamente denominadas doença fibrocística ou displasia mamária. Embora tais termos antigos ainda sejam utilizados pelos médicos, é importante entender que eles são sinônimos.

Clinicamente estes termos têm sido aplicados a uma condição na qual existem alterações na palpação, associadas ou não à dor, e sensibilidade aumentada, principalmente no período pré-menstrual. A maioria das mulheres apres enta mamas irregulares à palpação, sendo que estas irregularidades podem ser confundidas com tumores (INCA, 2002). Algumas dessas irregularidades são:

$\Rightarrow$ Cisto mamário - É a manifestação clínica e ultra-sonográfica mais freqüente encontrada na mama e que se enquadra no grupo das alterações funcionais benignas das mamas.

$\Rightarrow$ Fibroadenoma - Apresenta-se como nódulos de tamanhos variados, firmes e bastante móveis. São característicos da mulher jovem e têm crescimento limitado. Os fibroadenomas, como todos os tumores benignos, têm um comportamento de expansão apenas local. Seu 
tratamento resumese à remoção do nódulo e o estudo ao microscópio, permitindo o diagnóstico diferencial de certeza com o câncer.

$\Rightarrow$ Processos inflamatórios - As mamas podem ser sede de infecções ocasionadas por germes que habitam a superfície da pele, as quais são mais freqüentes no período da amamentação e desencadeadas pela penetração de tais germes através das aréolas ou papilas. As mastites caracterizam-se pelo aumento do volume da mama, pela presença de vermelhidão da pele, calor local e edema, acompanhados de pus e dor local.

$\Rightarrow$ Densidades Assimétricas - as densidades assimétricas podem ser confundidas com nódulos, já que apresentam características semelhantes. Podem ser causadas por cicatrizes pós-operatórias ou inflamações, como mostrado na Figura 2-4.

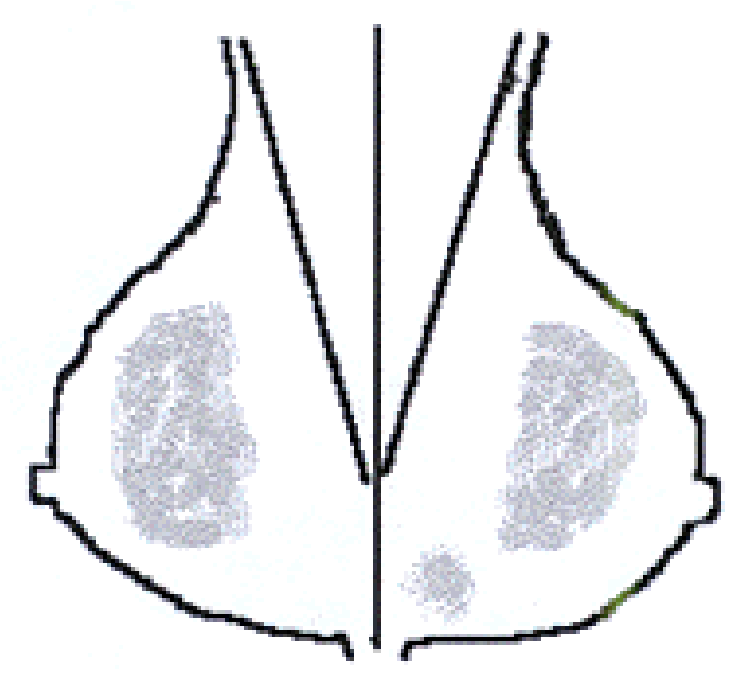

Figura 2-4 - Esquema da densidade assimétrica na projeção dos quadrantes inferiores da mama esquerda (Fonte: http://www.hps.com.br/medicinanuclear/mamoalta.htm).

Já o carcinoma mamário tem muitas faces, tal a variedade de sinais com que se pode apresentar, divididos em diretos e indiretos.

Sinais Diretos:

$\Rightarrow$ Opacidade circunscrita: Corresponde ao nódulo, sendo o achado mamográfico encontrado em $39 \%$ dos casos de câncer não palpáveis. Os 
nódulos devem ser analisados de acordo com o tamanho, densidade, contorno.

$\Rightarrow$ Contorno Espiculado ou Estrelado: corresponde ao chamado carcinoma cirroso. Nódulo de alta densidade com bordas espiculadas, geralmente é diagnosticado como carcinoma, como mostrado na Figura 2-5.

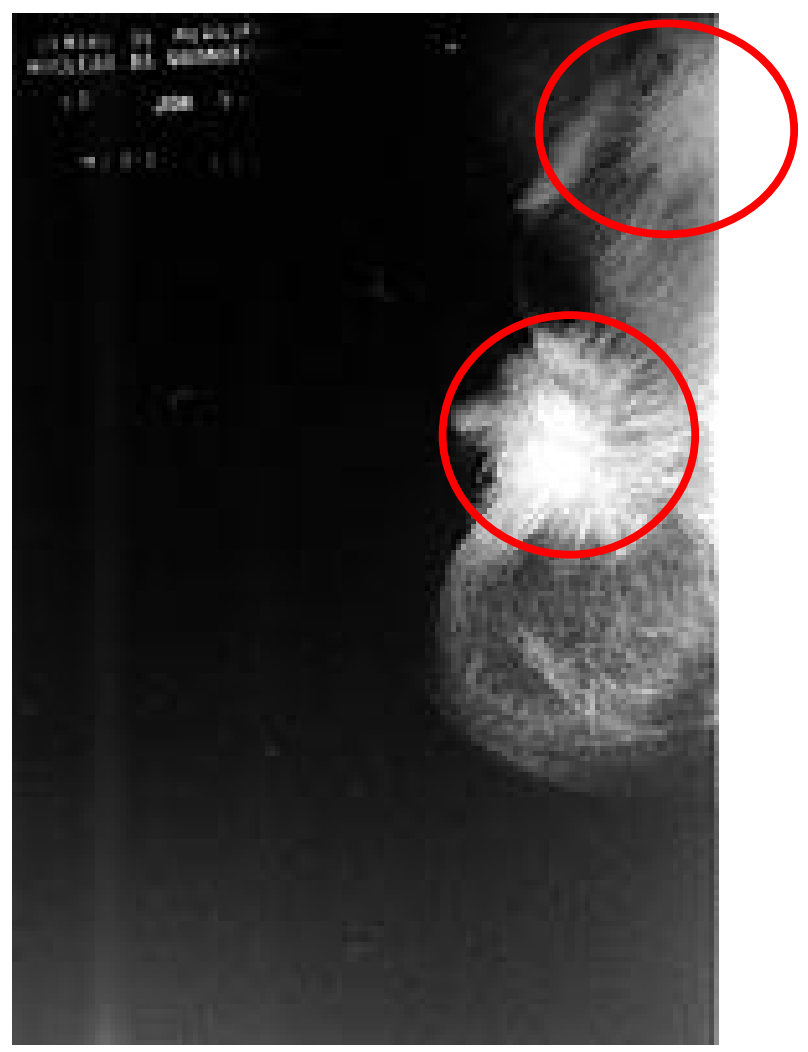

Figura 2-5 Incidência MLD, demonstra 2 lesões nodulares de bordas espiculadas. A maior em região retro-areolar determinando retração do complexo aréolo-papilar. A menor localizada junto ao prolongamento axilar.

$\Rightarrow$ Contorno lobulado: $\mathrm{O}$ aspecto lobulado representa um crescimento tumoral e essa característica autoriza uma suspeição de malignidade, sobretudo se parte do contorno é mal definida ou atenuada. 
Algumas lesões benignas como fibroadenoma, pequenos hematomas e papilomas também podem exibir um aspecto lobulado como ilustrado nas Figuras 2-6, 2-7 e 2-8.

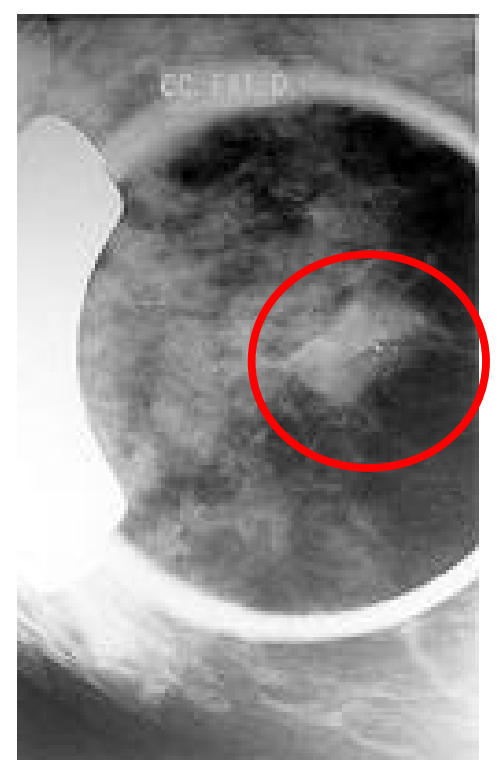

Figura 2-6 Incidência de magnificação da mama direita: Nódulo de contorno lobulado e limites parcialmente definidos com microcalcificações pleomórficas no seu interior (Lesão com Alto Índice de Suspeição Mamográfica).

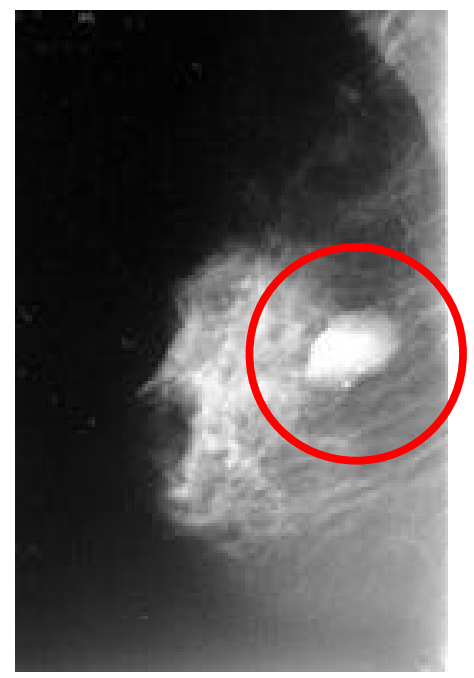

Figura 2-7 Incidência MLD: Nódulo de contorno lobulado e limites bem definidos, com calcificações grosseiras no seu interior. (Fibroadenoma) 


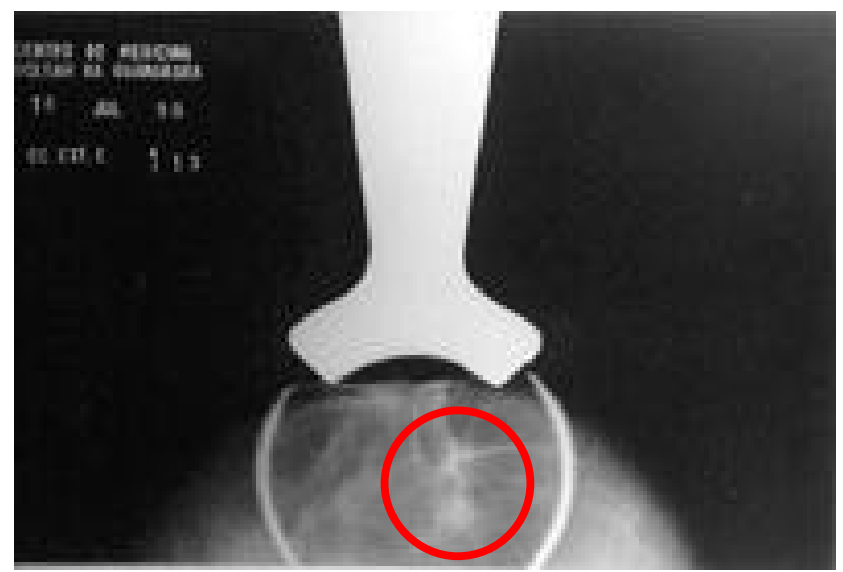

Figura 2-8 Incidência focada em CCE: Pequeno nódulo de limites parcialmente de finidos em região retro areolar.

$\Rightarrow$ Contorno bem definido: Característica de benignidade. No entanto, os tumores do tipo medular, colóide e mucinoso podem apresentar contorno bem definido. Para o diagnóstico com cistos a complementação com ecografia (ultra-sonografia) é imprescindível, até mesmo para se afastar a possibilidade de carcinoma intracístico. (Figura. 2-9)

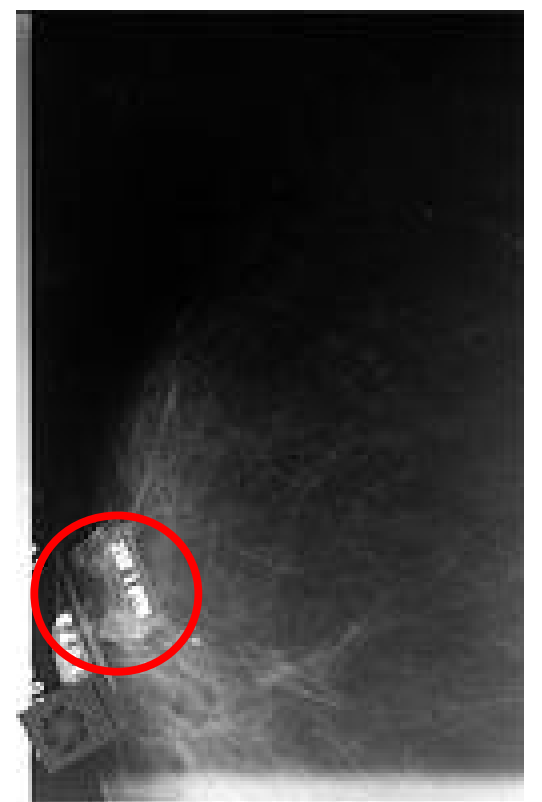

Figura 2-9 Incidência em magnificação CCD: Pequeno nódulo de contorno regular e limites precisos localizados na projeção dos quadrantes internos. 
Os sinais indiretos são a dilatação monoductal, contração ou retração tecidual, vascularização aumentada regionalmente, padrão ductal proeminente setorial, espessamento da pele e outros (INCA, 2002). Todos esses sinais, quando percebidos, pedem uma $m$ aior atenção na área envolvida:

$\Rightarrow$ Densidade: Os carcinomas têm densidade média ou elevada. Raramente apresentam densidade baixa. Os nódulos de média densidade são aqueles que permitem ver por superposição outras estruturas como, por exemplo, veias. Na maioria das vezes os carcinomas papilíferos e mucinosos se apresentam com densidade média.

$\Rightarrow$ Tamanho: Avalia-se que os nódulos mamários tornam-se palpáveis a partir de $1 \mathrm{~cm}$ de diâmetro. Considerando-se que o tempo de duplicação médio é de 180 dias, isto significa que para ser clinicamente detectável, o carcinoma levaria de 5 a 7 anos. Com base nos mesmos cálculos deduzse que a mamografia permitiria esta detecção em 1 a 2 anos antes, o que pode significar importante redução na mortalidade. $O$ correto acompanhamento do tamanho tumoral também ajuda no diagnóstico diferencial entre lesões malignas e benignas, que possuem um crescimento mais lento.

\subsection{A Densidade da Mama}

A preocupação médica com as mamas densas é devida à grande dificuldade de detecção de tumores em estágio precoce neste tipo de mama. Para minimizar este problema, a principal recomendação é a implantação de programas de rastreamento (screening), isto é, a execução de exames periódicos preventivos a partir de determinada idade. Os resultados desses programas permitem 0 acompanhamento da mudança do padrão mamográfico, devido principalmente ao aumento da idade da paciente.

Alguns médicos afirmam que o problema de mamas densas tem sido agravado pela utilização de tratamento para reposição hormonal, realizado em 
muitos países, conforme afirmam Jenks (1994) e Laya et al. (1995). Mulheres enquadradas em faixas etárias que antes não apresentavam mamas densas, podem apresentar esta característica em função da terapia. Considerando que a faixa etária é um dos fatores que mais determinam o risco do desenvolvimento da doença - estatísticas indicam que mulheres após 50 anos têm maior risco do que mulheres mais jovens (Byrne,1995) - a reposição hormonal vem a ser um grande problema na detecção através de imagens: alguns radiologistas acreditam que este tipo de terapia vem perpetuando a alta densidade de tecidos, podendo obscurecer tumores na mamografia. Estima-se que em torno de $20 \%$ de mulheres submetidas à terapia de reposição hormonal apresentam desenvolvimento na densidade da mama (Jenks, 1994). Apesar de não haver, na classe médica, uma opinião unânime sobre o relacionamento entre densidade e risco de desenvolvimento do câncer, na literatura geralmente a densidade da mama é considerada como um fator de risco em relação à doença (Jenks, 1994).

O relacionamento entre a densidade mamográfica e o risco de desenvolvimento do câncer de mama foi objeto de estudo de Byng et al. (1994; 1998). Além de apresentar resumos de trabalhos que confirmam este relacionamento, os p esquisadores apresentaram uma técnica de limiarização interativa que contabiliza a porção densa de mamogramas e que, de acordo com os autores, pode ser uma ferramenta para o monitoramento de mudanças parenquimais durante o acompanhamento preventivo. A técnica consiste em duas limiarizações: a primeira para detectar as bordas da mama, separando a estrutura mamária do fundo da imagem e a segunda para identificar porções densas na imagem avaliada. O método foi avaliado por radiologistas que auxiliaram na definição do valor ideal de limiar e apresentou, conforme afirmação dos autores, resultados aprovados pelos avaliadores.

Pesquisadores da França e Inglaterra - Hajnal et al. (1993) e Taylor et al. (1994) - também propuseram a classificação de mamogramas por densidade através de técnicas computadorizadas. A classificação apresentada por esses pesquisadores considerou estatísticas locais e medidas de texturas para dividir os mamogramas em gordurosos ou densos. Nesses estudos 
incluíram apenas mamogramas com tecidos normais. Chegaram à conclusão de que a classificação prévia de mamogramas nessas categorias é importante tanto para a utilização do médico quanto para os sistemas automatizados, visto que a presença de mamogramas de mamas densas exerce sérias influências na detecção de anormalidades auxiliadas por computador.

Van Gils et al. (1995) afirmaram que tumores encontrados em mamas com parênquimas densos são difíceis para detectar e podem estar em um estágio mais avançado quando diagnosticados. Por isso, é acons elhável um intervalo mais curto de rastreamento para mulheres com este tipo de mama. Porém, antes de recomendar tal estratégia, é necessário que se conheça o quão freqüentemente parênquimas de mamas densas estão presentes nas populações de rastreamento. Com a finalidade de colaborar com esta necessidade, acompanharam as mudanças nos padrões de mama de 1177 mulheres com idade entre 35 e 85 anos que fizeram parte de um programa de rastreamento na Holanda durante 12 anos. Concluíram que após este intervalo de tempo, 39\% das mulheres que apresentavam padrão P2 ou DY (na classificação de Wolfe) no primeiro exame tiveram seu padrão alterado para N1 ou P1. Verificaram ainda que os resultados sustentaram a hipótese de que a presença destes padrões de mamas densas (descritos detalhadamente no item 2.4 deste capítulo), apresentou-se inversamente proporcional à faixa etária das pacientes.

Mais tarde, este grupo de pesquisadores (Van Gils et al., 1998) publicou resultados sobre a influência da densidade da mama na performance dos programas de rastreamento. Com o mesmo banco de dados do estudo anterior, verificaram a quantidade de casos diagnosticados em mulheres com mamas densas e não densas. Concluíram que no início daquele programa de rastreamento, a densidade da mama apresentou um efeito desfavorável na descoberta de tumores e que a aquisição de aparelhos mamográficos mais modernos proporcionou uma diminuição deste efeito na detecção de tumores com tempo de desenvolvimento maior que um ano. Para resolver este problema, os autores recomendaram a pesquisa sobre a influência de intervalos mais curtos nos programas de rastreamento e a consulta a 
mamogramas com incidências adicionais ou, ainda, o uso de técnicas mais avançadas, como a mamografia digital, em mulheres com mamas densas.

As características mamográficas e o risco de ocorrência do câncer de mama foram também estudados por Byrne et al. (1995), cujas pesquisas continham dois objetivos básicos: avaliar a associação entre as características mamográficas e os fatores de risco do câncer de mama e avaliar os efeitos dessas características sobre o câncer de mama através do tempo, idade e estado de menopausa. Os pesquisadores afirmaram que a densidade é um fator ao qual muitas vezes não é dada importância. No entanto, verificaram que nos quase 2000 casos analisados, o risco quase dobrou quando a mulher apresentava alguma densidade na mama. Para mulheres com densidade acima de $75 \%$, o risco subiu para mais que quatro vezes. Os autores sugerem que a densidade da mama deveria, inclusive, ser um critério de seleção de mulheres para programas de rastreamento e influenciar na freqüência de exames. Hoje, no entanto, somente a idade da paciente é utilizada para tal fim.

A variação da densidade de acordo com a idade também foi verificada por Stomper et al. (1996). Foram classificados mamogramas de 1353 mulheres com idade entre 25 e 79 anos, a fim de determinar a freqüência e distribuição de mamogramas densos e os fatores que afetam a densidade parenquimal. Os resultados obtidos indicaram que, como esperado, a densidade diminuiu progressivamente em pacientes com idade entre 25 até 79 anos. No primeiro grupo (mulheres com idade entre 25-29 anos), 38\% das mulheres apresentavam mamas compostas predominantemente por gordura. No último grupo, esta porcentagem subiu para $76 \%$. Os pesquisadores descobriram também que o aumento da densidade parenquimal foi mais comum em mulheres com mamas menores e que tinham tido menos que duas gravidezes, assim como em mulheres submetidas à terapia de reposição hormonal. Neste último grupo, foi apontado que 49\% de mulheres entre 50 e 79 anos submetidas à terapia de reposição hormonal apresentaram mamas predominantemente densas; uma porcentagem similar (48\%) foi encontrada no grupo de pacientes com idade entre 40-44 anos. Os resultados mais detalhados podem ser observados na Tabela 2-1. 
Tabela 2-1 - Densidade parenquimal em mamogramas de mulheres de 25 a 79 anos (Stomper et al., 1996).

\begin{tabular}{|c|cc|cc|cc|cc|c|}
\hline \hline \multirow{2}{*}{ Idade } & \multicolumn{7}{|c|}{$\begin{array}{c}\text { Densidade parenquimal } \\
\text { Número de pacientes (\%) }\end{array}$} \\
\cline { 2 - 9 } & \multicolumn{2}{|c|}{$<\mathbf{1 0} \%$} & \multicolumn{2}{|c|}{$\mathbf{1 0 - 4 9 \%}$} & \multicolumn{2}{|c|}{$\mathbf{5 0 - 8 9 \%}$} & \multicolumn{2}{|c|}{$\geq \mathbf{9 0 \%}$} & Total \\
\hline $\mathbf{2 5 - 2 9}$ & 10 & $(10)$ & 27 & $(27)$ & 24 & $(24)$ & 39 & $(39)$ & 100 \\
$\mathbf{3 0 - 3 4}$ & 9 & $(7)$ & 31 & $(25)$ & 34 & $(27)$ & 52 & $(41)$ & 126 \\
$\mathbf{3 5 - 3 9}$ & 18 & $(14)$ & 38 & $(30)$ & 27 & $(22)$ & 42 & $(34)$ & 125 \\
$\mathbf{4 0 - 4 4}$ & 20 & $(16)$ & 46 & $(37)$ & 37 & $(30)$ & 22 & $(18)$ & 125 \\
$\mathbf{4 5 - 4 9}$ & 21 & $(17)$ & 38 & $(38)$ & 32 & $(26)$ & 24 & $(19)$ & 125 \\
$\mathbf{5 0 - 5 4}$ & 28 & $(22)$ & 42 & $(33)$ & 33 & $(26)$ & 23 & $(18)$ & 126 \\
$\mathbf{5 5 - 5 9}$ & 17 & $(14)$ & 70 & $(56)$ & 26 & $(21)$ & 12 & $(10)$ & 125 \\
$\mathbf{6 0 - 6 4}$ & 35 & $(28)$ & 59 & $(47)$ & 23 & $(18)$ & 9 & $(7)$ & 126 \\
$\mathbf{6 5 - 6 9}$ & 22 & $(18)$ & 67 & $(54)$ & 29 & $(23)$ & 7 & $(6)$ & 125 \\
$\mathbf{7 0 - 7 4}$ & 34 & $(27)$ & 63 & $(51)$ & 17 & $(14)$ & 11 & $(9)$ & 125 \\
$\mathbf{7 5 - 7 9}$ & 34 & $(27)$ & 61 & $(49)$ & 23 & $(18)$ & 7 & $(6)$ & 125 \\
& & & & & & & & &
\end{tabular}

Pesquisadores do Canadian National Breast Cancer Screening Study (NBSS), fizeram uma classificação quantitativa relacionando a densidade mamográfica e o risco de desenvolvimento do câncer de mama. Boyd et al. (1995) avaliaram mais de 700 mamogramas com o objetivo de verificar se a densidade da mama teria relação com o risco de ocorrência do câncer. Os mamogramas selecionados foram divididos em dois grupos: um denominado grupo de casos e outro grupo de controle. O primeiro grupo era composto por 354 mamogramas de mulheres pertencentes a diversas faixas etárias, que tinha desenvolvido câncer invasivo nos 12 meses subseqüentes após o primeiro exame mamográfico. O grupo de controle era composto por 354 casos de mulheres com idades similares que não desenvolveram a doença no período considerado. Para classificar os mamogramas de acordo com a porcentagem de tecidos densos neles presente, foram utilizados dois métodos: classificação de radiologistas e classificação computacional. Os resultados obtidos estão resumidos na Tabela 2-2. Para o cálculo do fator de risco, foi criado um coeficiente Beta, que considera as seguintes variáveis: idade da menarca, número de gravidezes, idade do primeiro filho, histórico familiar de câncer de mama, altura e peso da mulher. 
O incremento no risco de câncer de mama para cada categoria foi calculado pela fórmula:

$$
\boldsymbol{R}=\boldsymbol{e}^{\text {Beta }}
$$

Onde:

$$
R=\text { fator de risco. }
$$

De acordo com os autores da pesquisa, o estudo permitiu concluir que a densidade da mama é um fator de risco importante para o câncer de mama, apresentando um risco maior em mulheres com idade entre 40 a 59 anos. Enfatizaram também que estes resultados poderiam ser usados para estabelecer o intervalo de exames em programas de rastreamento.

Tabela 22 - Distribuição de casos de acordo com a densidade mamográfica e o risco de

\begin{tabular}{|c|c|c|c|c|c|c|c|}
\hline \multirow[b]{2}{*}{$\begin{array}{l}\text { Idade de } \\
\text { entrada no } \\
\text { NBSS }\end{array}$} & \multicolumn{7}{|c|}{ Proporção da mama ocupada por densidades (\%) } \\
\hline & Nenhuma & $<10$ & $10-25$ & $25-50$ & $50-75$ & $\geq 75$ & $\begin{array}{c}\text { Total de } \\
\text { casos }\end{array}$ \\
\hline \multicolumn{8}{|c|}{ TODAS AS IDADES } \\
\hline $\begin{array}{l}\text { Grupo de } \\
\text { casos }\end{array}$ & 10 & 29 & 65 & 94 & 90 & 66 & 354 \\
\hline $\begin{array}{l}\text { Grupos de } \\
\text { controle }\end{array}$ & 25 & 61 & 73 & 97 & 67 & 31 & 354 \\
\hline Total & 35 & 90 & 138 & 191 & 157 & 97 & 708 \\
\hline $\begin{array}{l}\text { Risco } \\
\text { Relativo }\end{array}$ & 1.0 & 1.2 & 2.2 & 2.4 & 3.4 & 5.3 & \\
\hline \multicolumn{8}{|c|}{ ENTRE 40-49 ANOS DE IDADE } \\
\hline $\begin{array}{l}\text { Grupo de } \\
\text { casos }\end{array}$ & 3 & 9 & 22 & 35 & 51 & 46 & 166 \\
\hline $\begin{array}{l}\text { Grupos de } \\
\text { controle }\end{array}$ & 10 & 17 & 25 & 40 & 49 & 25 & 166 \\
\hline Total & 13 & 26 & 47 & 75 & 100 & 71 & 332 \\
\hline $\begin{array}{l}\text { Risco } \\
\text { Relativo }\end{array}$ & 1.0 & 1.8 & 2.9 & 2.9 & 3.5 & 6.1 & \\
\hline \multicolumn{8}{|c|}{ ENTRE 50-59 ANOS DE IDADE } \\
\hline $\begin{array}{l}\text { Grupo de } \\
\text { casos }\end{array}$ & 7 & 20 & 43 & 59 & 39 & 20 & 188 \\
\hline $\begin{array}{l}\text { Grupos de } \\
\text { controle }\end{array}$ & 15 & 44 & 48 & 57 & 18 & 6 & 188 \\
\hline Total & 22 & 64 & 91 & 116 & 57 & 26 & 376 \\
\hline $\begin{array}{l}\text { Risco } \\
\text { Relativo } \\
\end{array}$ & 1.0 & 1.0 & 1.9 & 2.2 & 4.6 & 7.1 & \\
\hline
\end{tabular}
desenvolvimento de câncer (Boyd et al., 1995). 


\subsection{Classificação da Mama Segundo a Densidade}

A densidade da mama é um fator decisivo na qualidade da imagem radiológica e, conseqüentemente, na exatidão do diagnóstico. Assim como acontece com outros conceitos usados e m mamografia, não há um consenso sobre qual método usar quando a finalidade é classificar padrões mamográficos de parênquimas associados com o risco do câncer de mama, conforme afirmam Gram et al. (1997). Uma das mais citadas na literatura é a classificação de Wolfe (1976), que foi o primeiro pesquisador a descrever um esquema de classificação para densidade parenquimal, conforme afirmam Van Gils et al. (1995) e Jackson et. al. (1993). De acordo com Wolfe, há quatro categorias de densidade:

$\Rightarrow \mathbf{N 1}$ - mama composta principalmente de gordura, com pequenas quantidades de displasia - apresentam baixo risco de ocorrência de câncer;

$\Rightarrow \boldsymbol{P 1}$ - mama cujos dutos proeminentes ocupam um quarto ou menos do seu volume - apresentam risco intermediário de ocorrência de câncer;

$\Rightarrow \boldsymbol{P} \mathbf{2}$ - dutos proeminentes ocupam mais que um quarto do volume da mama - apresentam risco intermediário de ocorrência de câncer;

$\Rightarrow D Y$ - mamas que têm alta displasia mamária - apresentam alto risco de ocorrência de câncer.

De acordo com Jackson et al. (1993), o Colégio Americano de Radiologia apresenta uma classificação mais recente de densidade mamária, na qual a quantidade de densidade está correlacionada com o potencial de sensibilidade da mamografia. Nesta classificação, uma mama pode ser enquadrada em uma das seguintes classes, de acordo com sua densidade:

$\Rightarrow$ Quase inteiramente gordura;

$\Rightarrow$ Elementos fibroglandulares espalhados que podem obscurecer uma lesão;

$\Rightarrow$ Heterogeneamente densa, podendo diminuir a sensibilidade da mamografia; 
$\Rightarrow$ Extremamente densa, com baixa sensibilidade mamográfica.

A classificação Tábar, apresentada por Gram et al. (1997), sugere um esquema classificatório com base em correlações anatômico-mamográficas, dividindo os mamogramas em 5 categorias:

$\Rightarrow$ Categoria I - possui três características principais: c ontornos enrugados e ligamentos de Cooper, unidades lobulares ductais terminais espalhadas, áreas transparentes de forma oval correspondente à formação de gorduras;

$\Rightarrow$ Categoria II - representam formações completas de gordura;

$\Rightarrow$ Categoria III - combinação de padrão ductal proeminente retro-areolar devido a elastose peridutal e interiorização de gordura;

$\Rightarrow$ Categoria IV-demonstra densidades lineares e nodulares extensivas ao longo da mama;

$\Rightarrow$ Categoria $\boldsymbol{V}$ - consiste em fibroses sem estruturas, homogêneas, parecidas com vidro, com contorno convexo.

\subsection{Fatores que Dificultam a Aquisição da Imagem da Mama}

Cálculos estatísticos apresentados por Jackson et al. (1993) indicaram que cerca de $25 \%$ das mulheres apresentam mamas densas. Os pesquisadores concluíram que a dificuldade de produzir mamogramas deste tipo de mama é devida a vários fatores físicos:

$\Rightarrow$ As lesões mamárias têm propriedade de atenuação de raios- $X$ similares àquelas de tecidos glandulares e fibrosos, o que torna sua detecção mais difícil;

$\Rightarrow$ A mama radiograficamente densa produz mais radiações espalhadas, resultando em menor contraste na imagem; 
$\Rightarrow$ Este tipo de mama tem mais tecidos não homogêneos e um grande intervalo de atenuações, tornando difícil expor, de forma ótima, todas as suas áreas;

$\Rightarrow$ Esta categoria de mama requer exposições mais altas para encontrar densidades óticas adequadas do filme. Isto acarreta um segundo problema: para aparelhos com saídas fixas, o tempo de exposição deve ser mais longo para mamas densas, aumentando a possibilidade de borramento por movimento.

Diante das dificuldades de radiografar a mama densa, os pesquisadores citam o que tem sido feito para melhorar a aquisição da imagem para este tipo de mama, sendo que a maioria das ações aplica-se ao aparelho mamográfico e suas rotinas no exame: uso de grades para diminuição do espalhamento, utilização de incidências suplementares com compressão em pontos localizados, magnificação mamográfica, melhorias no controle de exposição automático, combinações écran-filme mais adequadas, técnicas de equalização de exposição e mamografia digital são alguns dos itens citados pela equipe. Afirmam ainda que outras técnicas estão sendo utilizadas como alternativas para a obtenção da imagem desta classe de mamas: ultra-som, transiluminação, termografia, ressonância magnética nuclear, tomografia computadorizada e angiografia por subtração digital, além de técnicas de medicina nuclear. Finalizando sua exposição sobre mamas densas, os pesquisadores sugerem que alguns pontos deveriam ser pesquisados para uma otimização nesta área. Entre esses pontos, citam a ignorância global a respeito da porcentagem de mamogramas de mamas densas que se tornam inúteis devido à exposição, compressão ou posicionamento inadequados, ou borramento devido à movimentação da paciente. Relatam também que não há estimativas confiáveis sobre a porcentagem e o tipo de câncer que não são detectados em mamas densas. Tais questões, afirmam os pesquisadores, deveriam ser estudadas a fim de auxiliar na detecção precoce do câncer também em mulheres com este tipo de mama. 


\section{Capítulo 3 - Mamografia}

A mamografia constitui uma forma particular de radiografia, que trabalha com níveis de tensões e correntes em intervalos específicos, destinada a registrar imagens da mama a fim de diagnosticar a presença ou ausência de estruturas que possam indicar doenças.

Segundo o INCA (INCA, 2002), em uma mamografia, duas incidências de cada mama são indispensáveis: uma visão lateral ou oblíqua (Figura 3 -1) e uma crânio-caudal (Figura 3-2). No entanto, a incidência médio-lateratoblíqua (MLO) é a mais eficaz, pois mostra uma quantidade maior de tecido mamário e inclui estruturas mais profundas do quadrante súpero-externo e do prolongamento axilar. Como a mama repousa sobre o músculo peitoral, uma grande parte deste deverá ser incluída na imagem. Este objetivo será atingido se o posicionamento do receptor da imagem do aparelho for paralelo ao plano muscular, expondo a máximo possível de tecido mamário e axilar. O músculo deverá estar presente na imagem pelo menos até a linha mamilar posterior e, segundo a literatura, isto é possível em $80 \%$ das pacientes. É também desejável que seja demonstrada a gordura retro-glandular para que se tenha certeza da exposição de todo o tecido fibroglandular. Dobras de pele podem ocorrer na axila, mas não sobre o tecido mamário, sob risco de obscurecer ou mimetizar uma lesão. A incidência crânio-caudal (CC), tem como objetivo incluir todo o material póstero-medial, complementando a médio-lateraloblíqua, que com freqüência não está totalmente demonstrado na incidência MLO. Permite também mais compressão como demonstrado na Figura 3-3, uma vez que não inclui a axila, resultando em uma superior definição da arquitetura mamária e de lesões. A melhor maneira de verificar se a incidência CC inclui suficiente tecido é comparar a sua linha mamilar posterior com a da incidência MLO. A diferença entre estas medidas não deve ser superior a 1,0 $\mathrm{cm}$. A visualização do músculo peitoral nesta incidência é desejável, mas 
possível em apenas $30 \%$ das pacientes. Outro critério na avaliação da incidência CC é a posição do mamilo, que deve estar localizado na linha média (Vieira, 2000).

As incidências crânio -caudais e as médio -laterais devem ser estudadas aos pares, de modo a permitir a comparação de regiões simétricas, pois qualquer assimetria pode ser indício de patologia.

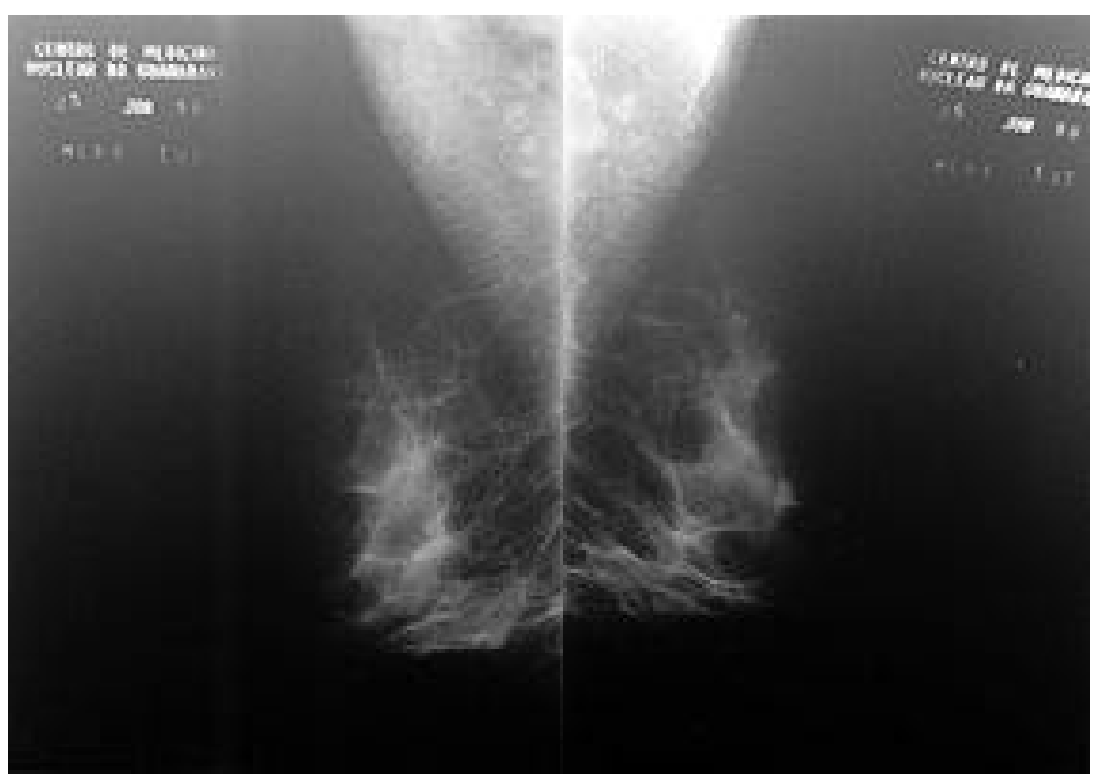

Figura 3-1 - Incidência Médio-lateral (ML) das mamas, em um exame normal de boa qualidade técnica. 


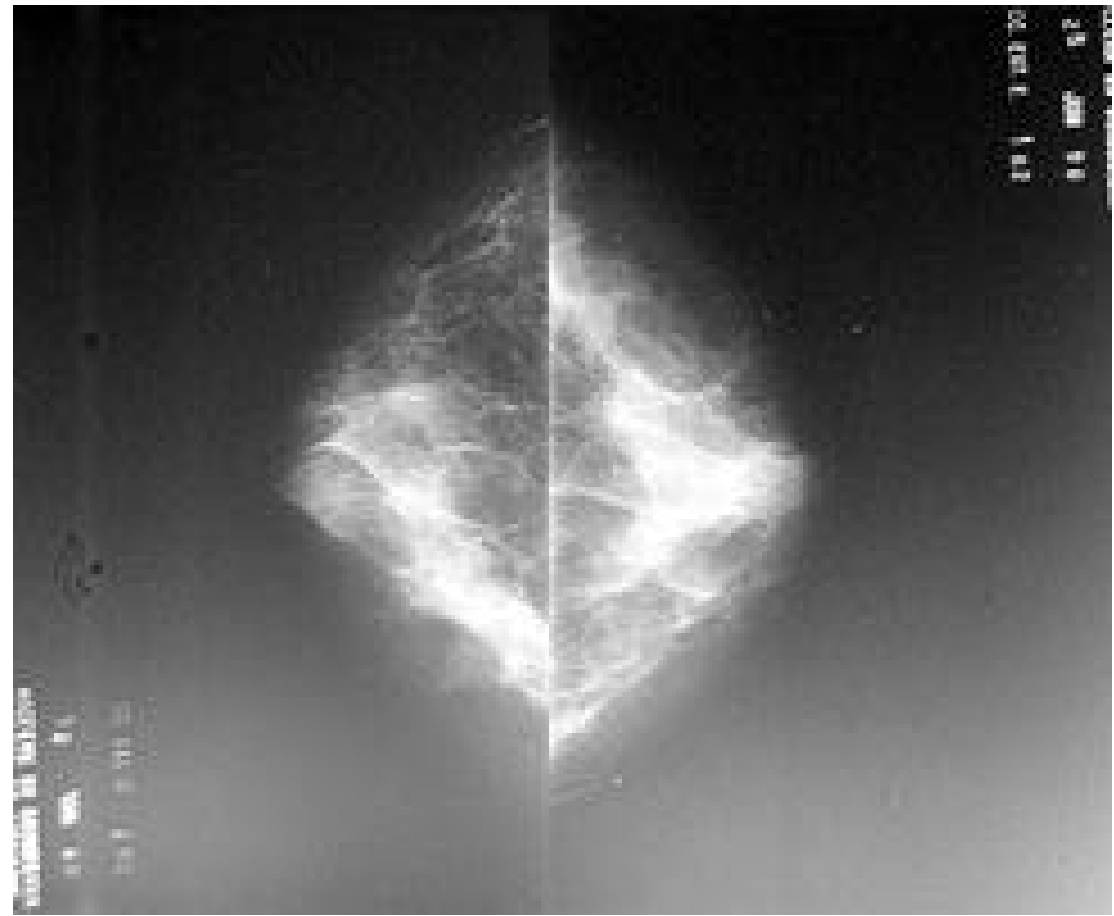

Figura 3-2 - Incidência Crânio Caudal (CC) das mamas, em um exame normal de boa qualidade técnica.

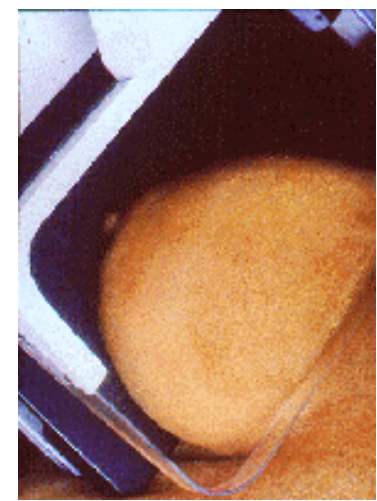

Figura 3-3 - Compressão da mama para realização da mamografia com a Incidência Crânio Caudal (CC).

A mamografia é um exame de alta sensibilidade, apesar de a maioria dos estudos evidenciarem perdas entre 10 a 15\% dos casos de câncer com tumor detectável ao exame clínico (INCA, 2002). Esta sensibilidade, no entanto, está diretamente relacionada à idade da mulher, sendo muito menor 
nas mulheres jovens, que apresentam uma alta densidade de tecido mamário, devido à predominância de tecidos fibroglandulares na sua composição.

O reconhecimento de estruturas que possam indicar a presença de câncer se dá através da constatação de uma diferença de contraste entre os diversos tecidos envolvidos. A gordura, por exemplo, absorve uma menor quantidade de raios- $X$, aparecendo mais escura no mamograma, enquanto tecidos fibroglandulares apresentam densidade óptica maior e aparecem mais claros (Boyd, 1995). Geralmente microcalcificações e massas aparecem em tonalidades mais claras na imagem obtida após a revelação do filme mamográfico, mas essa diferenciação fica prejudicada em imagens de mamas densas. Por esse motivo, muitas vezes a descoberta do câncer de mama em mulheres com menos de 40 anos de idade acontece quando o tumor já apresenta um desenvolvimento avançado, o que dificulta o tratamento da doença.

Um agravante a essa questão é a terapia de reposição hormonal (TRH) que, segundo alguns pesquisadores (Jenks, 1994), pode perpetuar a alta densidade de tecidos, fazendo com que mulheres enquadradas em faixas etárias que antes não apresentavam mamas densas, passem a apresentar esta característica em função da terapia. Como a faixa etária é um dos fatores que determinam o risco do desenvolvimento da doença (Byrne, 1995), a reposição hormonal vem a ser um grande problema na detecção através de imagens, podendo dificultar a visualização de estruturas suspeitas em imagens mamográficas.

O diagnóstico de carcinomas não-palpáveis só é possível através da realização de mamografias minuciosas, onde cada detalhe é de extrema importância para evitar os diagnósticos falso-positivos, que aumentam os números desnecessários de biópsias e os falso-negativos que podem levar a um retardo na biópsia, e o prognóstico pode ser adversamente afetado (Bland\&Copeland, 1994). As causas mais importantes de mamogramas falsosnegativos são as seguintes: 
$\Rightarrow$ Tecido mamário denso: quando há insuficiente gordura para separar a anormalidade do parênquima mamário circunvizinho, então a mamografia pode deixar de identificar uma anormalidade palpável. Se uma lesão for clinicamente palpável, mas tiver achados negativos na mamografia, ele deve ser investigado adicionalmente. Ultra-som pode ser de valor para demonstrar uma anormalidade que é clinicamente palpável, porém mamograficamente negativa, e para localizar a lesão para biópsia de aspiração.

$\Rightarrow$ Fatores técnicos: equipamento especializado segundo o estado da arte, mamografistas bem treinados, e radiologistas capazes de interpretar sinais sutis de câncer de mama são essenciais para limitar resultados falso-negativos. Apropriadamente efetuadas, a boa compressão e a demonstração da parede anterior do tórax contribuirão significativamente para a precisão global. Fatores técnicos inadequados, então aumentarão os resultados falsos -negativos.

$\Rightarrow$ Erros de interpretação: os erros primários de interpretação supõem que as lesões bem circunscritas são benignas, que as calcificações sem o padrão ramificado característico não podem ter uma base maligna, ou deixam de interpretar os sinais indiretos sutis de distorção parenquimatosa. Maior conhecimento e maior ênfase no treinamento podem tornar os radiologistas mais aptos para distinguir alterações parenquimatosas iniciais indicadoras de câncer de mama. A introdução de técnica adjuntiva e o uso mais confiável da citologia de aspiração, com biópsia guiada estereotaxicamente, podem ser de valor.

Os principais fatores que determinam a qualidade dos exames de mamografia são: a qualificação de pessoal técnico, o tipo de equipamento utilizado, a adesão a um programa de controle de qualidade, a interpretação dos exames, a comunicação dos resultados e, finalmente, um protocolo para seguimentos dos casos, possibilitando a auditoria do serviço.

O radiologista ao interpretar o exame deve estar apto a reconhecer possíveis problemas nas imagens e estabelecer suas causas. Ao avaliar uma 
mamografia, devem-se analisar diversos parâmetros como posicionamento, compressão, qualidade da imagem, presença de artefatos e identificação dos filmes (Yaffe,1995).

A compressão é fator importante para uma boa mamografia. Diminuindo a espessura da mama, diminui-se também a dose de radiação, possibilitando a adequada exposição de toda a mama numa única imagem e reduzindo a indefinição causada pelo movimento (Basset, 1993). A compressão inadequada pode causar sobreposição das estruturas da mama, exposição não uniforme do tecido mamário e imprecisão de contornos, dificultando a detecção de uma lesão.

Aperfeiçoamentos recentes na mamografia de filme/tela melhoraram consideravelmente a precisão diagnóstic a e reduziram as doses de radiação. Os benefícios adicionais da compressão incluem dosagens reduzidas de radiação, avaliação mais exata das densidades, e melhor visualização das bordas da lesão, que é capaz de distinguir densidades benignas de malignas.

Em uma recomendação recente do Colégio Americano de Radiologistas, o credenciamento é dado apenas às unidades que possuem equipamento mamográfico atualizado, pessoal treinado (radiográfico e radiológico) e controle de qualidade que assegure que a dose de radiação é mínima.

O estudo sobre o exame mamográfico é antigo. Em 1913, Salomon na Alemanha estudou radiograficamente $\mathbf{3 0 0 0}$ mamas amputadas e conseguiu diferenciar formas cirrosas de câncer dos tipos nodulares. Ele observou as microcalcificações nos carcinom as intraductais, mas deixou de reconhecer seu significado. Em 1927, Kleinschmidt escreveu um livro no qual descrevia a mamografia como auxílio no diagnóstico. Jacob Gershon-Cohen, de Filadélfia, estudou padrões radiológicos mamários de 1937 a 1948 e fez notável progresso no diagnóstico acurado dos tumores malignos. Ele advogou incansavelmente o uso de radiografias como auxílio ao diagnóstico clínico, e em 1948 foi o primeiro a demonstrar a exeqüibilidade de detectar carcinomas ocultos (Bland\&Copeland - 1994). Egan, em 1962, no M.D. Anderson Hospital 
no Texas, relatou um estudo clássico de 2522 mamogramas nos quais a diferenciação de tumores benignos e malignos foi feita sem o auxílio de achados clínicos. O temor de induzir câncer de mama pelos estudos mamográficos repetidos foi aliviado pela tecnologia aperfeiçoada com doses muito menores. A exatidão destes estudos progrediu para mais de $90 \%$, e levou ao descobrimento de carcinomas impalpáveis (Bland\&Copeland-1994).

Outros estudos foram desenvolvidos ao longo do tempo, como o estudo do "Health Insurance Plan (HIP), que demonstrou concludentemente uma redução de $33 \%$ na mortalidade em pacientes que foram triadas por mamografia, o que foi confirmado pelos dados do Projeto de Demonstração de Detecção de Câncer de Mama (PDDCM) (Baker, 1984). No câncer de mama, aumentar a precisão diagnóstica é possível apenas através de mamografia com raios - $\mathrm{X}$, a qual, quando executada e interpretada otimamente, é capaz de detectar lesões com menos de $5 \mathrm{~mm}$ de diâmetro. Várias experiências clínicas prospectivas controladas estabeleceram os benefícios da detecção precoce através da mamografia. O estudo HIP, a primeira experiência controlada randomizada a investigar a possibilidade de reduzir o índice de mortalidade pelo câncer de mama, foi um estudo prospectivo cientificamente projetado para determinar a eficácia da mamografia e exame físico. Os resultados iniciais demonstraram uma diminuição de $30 \%$ na mortalidade e foram sustentados em um acompanhamento de 18 anos. As experiências dos dois condados da Suécia, iniciadas em outubro de 1977 , demonstraram uma redução de $25 \%$ no número de cânceres estádio II ou mais avançados, e uma redução de $31 \%$ na mortalidade no grupo de estudo. Dois estudos não randomizados descritos na Holanda em 1984 (Collette,1984), demonstraram uma importante proteção nas pacientes que tinham sido triadas por mamografia. Os resultados combinados das experiências do HIP, PDDCM, suecas e holandesas indicam claramente que a detecção precoce pode alterar a história natural do câncer de mama.

Aceitar que a mortalidade pelo câncer de mama não possa ser alterada e que as estatísticas desanimadoras que persistiram por 100 anos antes de 1971 permanecerão inalteradas é insustentável. Na ausência da triagem do câncer de mama, a maioria dos cânceres serão detectados pela paciente ou 
por um clínico sob a forma de uma massa palpável, e em mais de 50\% destas pacientes terão ocorrido metástases nos linfonodos axilares. A história natural de uma doença pode, portanto, ser alterada pelo diagnóstico mamográfico precoce, o qual melhora grandemente a sobrevida e a qualidade de vida. $\mathrm{O}$ câncer mamário mínimo se associa a uma sobrevida de 20 anos de $93 \%$, em comparação com uma sobrevida de 5 anos de $20 \%$ nas pacientes com metástases à distância (Feig, 1988). O aperfeiçoamento contínuo na técnica mamográfica e na interpretação ao longo dos últimos anos pode ser aferido comparando-se os estudos do HIP com o PDDCM. O índice de detecção de câncer no estudo PDDCM foi duas vezes maior que no estudo HIP, mais provavelmente em virtude da maior sensibilidade da técnica e maior perspicácia diagnóstica. Parece que a triagem bienal para mulheres com 50 anos ou mais deve agora constituir o objetivo aceitável. A evidência de que a triagem beneficia mulheres mais jovens está se acumulando, e isto é importante à luz das observações de que as mulheres jovens sob medicação anticoncepcional são mais propensas a desenvolver câncer de mama. A efetividade do programa de triagem dependerá inteiramente da sensibilidade das técnicas. Quando a sensibilidade é alta, o objetivo (isto é, redução da mortalidade) será alcançado. Esta sensibilidade dependerá de equipamento atualizado, facilidades de processamento adequadas, radiologistas treinados e motivados, e uma população que tenha sido apropriadamente informada a respeito dos riscos e benefícios dos programas de triagem.

Poucos métodos diagnósticos para doença mamária foram avaliados tão completamente quanto a mamografia. Esta técnica é simples, aceitável pelas pacientes, pos sui alta sensibilidade e especificidade, é reprodutível, de baixo custo e possui uma baixa relação risco-benefício. Apropriadamente efetuada e interpretada, a mamografia possui uma sensibilidade acima de $90 \%$, porém a má técnica mamográfica pode ter conseqüências desastrosas para a paciente. A diminuição da sensibilidade e especificidade resultará em inúmeros cânceres não diagnosticados ou em intervenções cirúrgicas desnecessárias através de um aumento no índice falso-positivo. 
A técnica da mamografia é absolutamente crítica para suportar resultados aceitáveis. O equipamento deve ser o mais atualizado disponível, e os técnicos de radiografia devem ser de tempo integral no campo da mamografia, treinados ao mais alto nível, e especificamente motivados.

\subsection{O Equipamento Mamográfico}

O equipamento dedicado a mamografia (Figura 3-4) não é o mesmo utilizado pelos sistemas de raios- $X$ convencionais, possuindo características próprias. A imagem gerada deve ser de alta resolução para que se possam visualizar as estruturas mamárias que, por sua vez, são compostas de tecidos moles, cuja diferença nos níveis de absorção de raios-X é pequena entre si.

O compartimento de compressão é um acessório do sistema mamográfico e tem como função comprimir a mama por uma placa de um material radiotransparente até que se consiga a menor espessura possível. Ele é responsável por melhorar a resolução- levando as estruturas da mama mais próximas do filme - e por evitar a movimentação da mama, conseguindo, assim, uma dose menor de radiação. Isso diminui a espessura da mama, separando estruturas superpostas e ajudando na diferenciação entre massas sólidas e císticas.

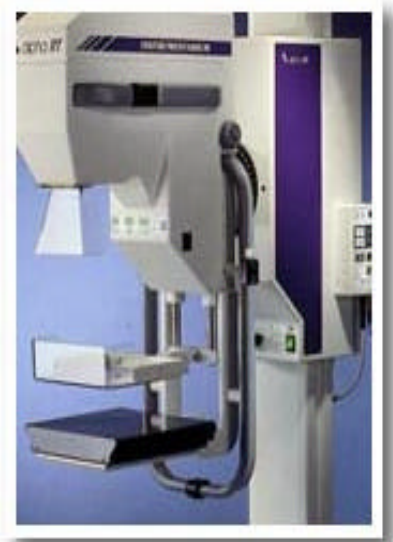

Figura 3-4 Ilustração de um mamógrafo (Fonte: http://www.uspar.com.br). 
Uma característica particular do equipamento mamográfico é a modificação do tubo de raios-X: enquanto geralmente é usado tubo de tungstênio nos sistemas convencionais, o mamógrafo utiliza tubo de molibdênio. Isto porque o feixe produzido num tubo de molibdênio tem um espectro que o aproxima de um feixe monoenergético, o que é conveniente no caso de radiografia de mamas devido aos tecidos que a constituem.

Outra característica peculiar é o campo de radiação que, no mamógrafo, é um pouco maior que a metade do campo dos sistemas convencionais. Para se conseguir isto, utilizam-se colimadores de feixes e restritores, que são espécies de direcionadores do feixe de raios-X e barradores de radiação. Eles ajudam a diminuir a dose de radiação ionizante em outras partes do corpo da paciente e também colaboram com a melhoria da imagem. Os filtros, que geralmente são de molibdênio, com cerca de 0,03mm, são os responsáveis por impedir que os fótons do feixe que nada acrescentam para o diagnóstico, atrapalhem na formação da imagem e atinjam a paciente, somando-se à dose de radiação recebida.

O ponto focal é outro fator de grande importância no sistema mamográfico; ele deve ser bem pequeno, pois estruturas de até $0,3 \mathrm{~mm}$ de diâmetro, como as microcalcificações, por exemplo, devem ser possíveis de visualizar. O chassi mamográfico apresenta um écran intensificador que, ao contrário do convencional, se posiciona em baixo do filme. Os fótons atravessam o filme, chegando pela sua base, atingem o écran, transformam-se em luz visível e são refletidos de volta, impressionando o filme. Esse posicionamento é utilizado para evitar o efeito "crossover" (fenômeno de o filme ser impressionado duas vezes pelo mesmo fóton de modo que isto possa causar uma certa penumbra na imagem, deteriorando a resolução), e também para ajudar na obtenção de uma melhor resolução da imagem, prevenindo uma grande absorção de fótons antes que eles se encontrem com o filme, pois, como os raios- $X$ na mamografia são de baixa energia, um simples écran poderia absorver mais que $50 \%$ dos fótons que chegam nele. 
O mamógrafo deve ser operado com potência constante ou trifásica, cujo feixe de raios $-X$ tem maior poder de penetração. Geralmente a tensão usada para mamografia varia de 25 a $50 \mathrm{kVp}$ (entre 28 e 32, para a maioria dos exames), valor que depende normalmente da espessura da mama (que normalmente, depois de comprimida, fica entre 3 e $8 \mathrm{~cm}$ ). O esquema descrito está exemplificado na figura 3-5.

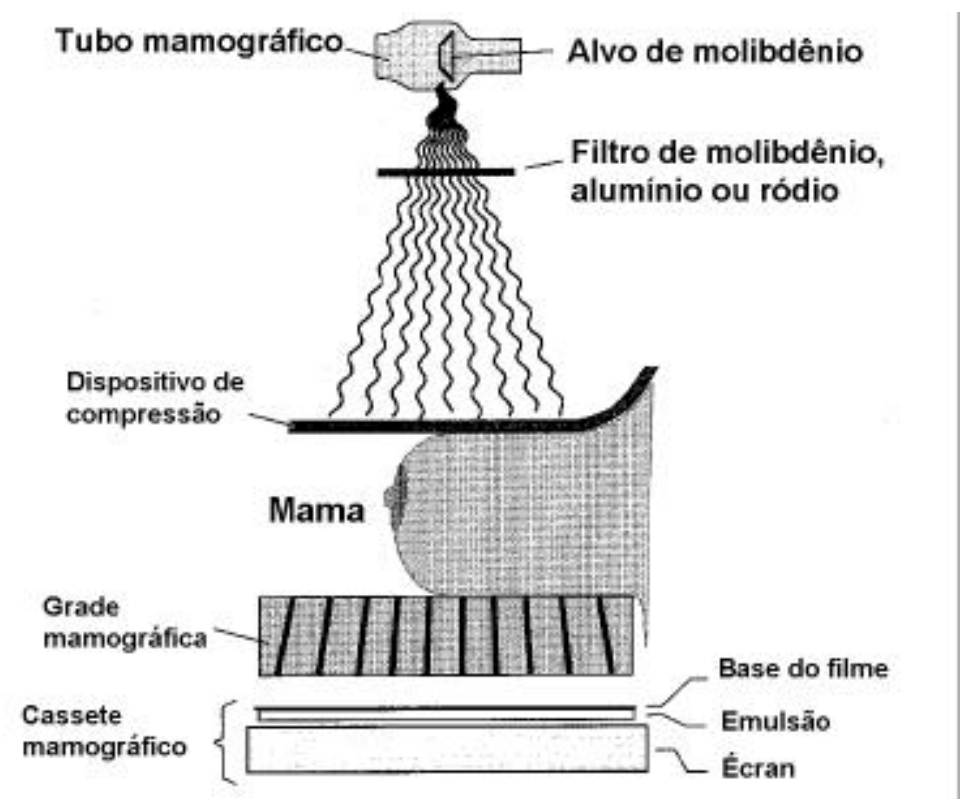

Figura 3-5 Esquema de um aparelho mamográfico durante a realização do exame (Wolbarst,1993).

Nos últimos 25 anos, os equipamentos mamográficos e os sistemas de registro écran-filme sofreram grandes avanços. Antigamente as imagens mamográficas eram obtidas através de equipamentos originalmente projetados para aquisição de imagens de outros órgãos, como o pulmão. Com o passar do tempo, acessórios foram acrescentados ou modificados a fim de que os aparelhos se tornassem adequados para registrar a imagem da mama. 


\subsection{1 - Mamógrafo Digital}

Os mamógrafos digitais começaram a surgir no final da década de 80 (Nishikawa, 1987), mas só no ano 2000 foi aprovado o primeiro equipamento de mamografia digital pelo departamento de saúde do FDA norte americano. $O$ mamógrafo digital consiste de um aparelho muito semelhante ao aparelho de mamografia convencional (tubo de Raios-X, dispositivo de compressão, colimadores, etc.), com exceção do sistema de registro, onde o filme e o écran são substituídos por detectores semicondutores sensíveis aos Raios- $X$, conforme ilustrado na Figura 3-6.

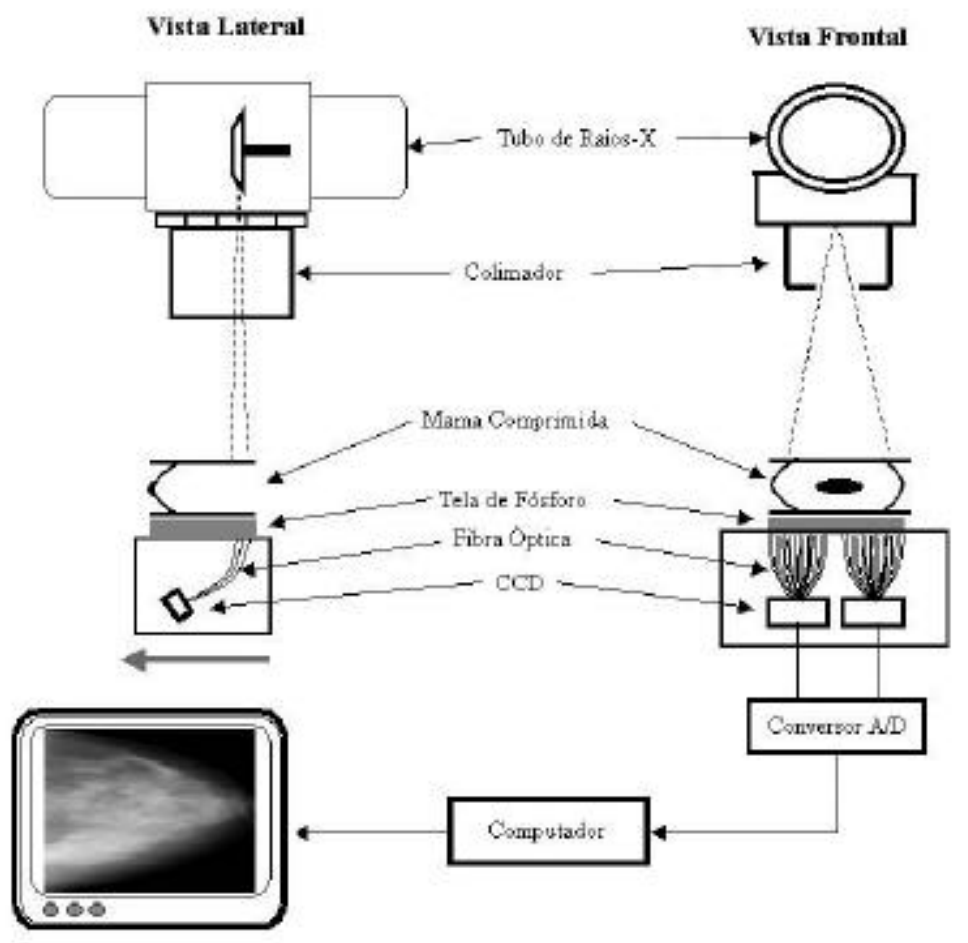

Figura 3-6. Esquema simplificado de um apareho de mamografia digital.

O processo de aquisição da imagem é feito diretamente pelos detectores, que convertem a radiação recebida em sinal elétrico, proporcional à intensidade de radiação detectada. Esse sinal é quantizado e convertido em sinal digital por um conversor A/D, formando a imagem digital. Basicamente, os mamógrafos digitais utilizam uma tela de fósforo para a detecção dos 
Raios-X, acoplada a uma matriz CCD (Charged Coupled Device) através de fibras ópticas. A resolução espacial do sistema digital é dada pelo tamanho dos detectores e do espaçamento entre eles, enquanto sua resolução de contraste é definida pela sensibilidade dos detectores e do número de bits do conversor A/D.

Na mamografia convencional, o sistema de aquisição da imagem pos sui limitações devido a sua resposta logarítmica à variação da intensidade da radiação que o irradia. Além disso, existem faixas de exposição, correspondentes à base e ao patamar da curva característica, que promovem baixo contraste na imagem. Na mamografia digital, o sinal armazenado é proporcional à intensidade de radiação que atinge os detectores, para toda a faixa de intensidade. Assim, a imagem digital reflete com muito mais precisão o contraste subjetivo presente nas estruturas internas da mama. Além disso, após a detecção e o processamento da imagem pelo computador, ela pode ser visualizada utilizando um monitor de alta resolução ou através da impressão da imagem digital em filme mamográfico especial (Hemminger, 1999).

\subsection{O Exame Mamográfico}

O exa me mamográfico é realizado da seguinte forma: o feixe de raios - $X$ é disparado e a imagem é registrada em filme. Após a revelação do filme, um radiologista interpreta o mamograma a fim de determinar se nele existe alguma área suspeita. Caso haja necessidade, uma nova mamografia pode ser solicitada com enfoque maior na região de interesse ou utilizando-se novas projeções e, caso o médico julgue necessário, uma biópsia é solicitada. No entanto, a título de prevenção, muitas pacientes acabam submetendo-se a biópsias desnecessárias. Estatísticas indicam que, para se obter segurança no diagnóstico, para cada câncer removido, de 5 a 10 mulheres são submetidas à biópsias. A diminuição das biópsias desnecessárias vem a ser um dos objetivos dos esquemas computadorizados de detecção precoce do câncer de mama, conforme afirmam Chan et al. (1987). 


\subsection{Alcance e Limitação da Mamografia}

Dadas suas características, a mamografia por raios-X é, ainda hoje, a técnica mais indicada e mais empregada no diagnóstico precoce do câncer de mama, como afirmam Dhawan et al. (1986); Dance (1990), Dengler et al. (1993), Shen et. al. (1993), Chan et al. (1994), Plewes et al. (1995) e Giger (2000). No Reino Unido, de acordo com Davies; Dance (1990) estima-se que um total de 1.440 .000 exames mamográficos são realizados por ano.

O posicionamento da mama deve incluir a maior parte das estruturas mamárias. Uma mamografia de bom padrão técnico deve demonstrar o seguinte:

$\Rightarrow$ Papilas perfiladas nas incidências crânio-caudais, os mamilos só devem ser observados com a luz forte.

$\Rightarrow$ Nas incidências médio-laterais visualizamos o músculo peitoral até a linha de projeção das papilas.

$\Rightarrow$ Realizar compressão adequada.

Na imagem revelada, não se deve encontrar:

$\Rightarrow$ Mamilos dobrados e sobrepostos ao parênquima mamánio.

$\Rightarrow$ Dobras de pele, bem como imagens do ombro, queixo ou nariz da paciente sobrepostos à imagem mamográfica.

$\Rightarrow$ Mama sobreposta com parte do cabelo da paciente (quando parte do cabelo sobrepõe-se a imagem).

$\Rightarrow$ Artefatos que possam surgir por não haver uma limpeza sistemática dos chassis de filmes e ou falta de cuidados na revelação. 


\subsection{Indicações da Mamografia:}

De acordo com o Colégio Brasileiro de Radiologia, a mamografia para rastreamento do câncer de mama, deve ser realizada em mulheres assintomáticas, com a seguinte periodicidade:

$\Rightarrow$ Entre 35 e 40 anos: mamografia de base, para determinar o padrão de mama da paciente com a finalidade de comparação com exames posteriores. Nos casos de história familiar importante (mãe ou irmã com câncer de mama), o primeiro exame poderá ser realizado antes dos 35 anos;

$\Rightarrow$ Entre 40 e 49 anos: mamografia bienal ou anual, se a paciente pertencer a grupo de risco;

$\Rightarrow$ De 50 anos em diante: mamografia anual.

Nos Estados Unidos, organizações como o American Cancer Society and the National Alliance of Breast Cancer Organizations sugerem que, a partir dos 40 anos, as mulheres realizem uma mamografia a cada um ou dois anos e, após a idade de 50 anos, sejam submetidas a um exame mamográfico anual.

Nas pacientes sintomáticas a indicação não seguirá o padrão acima e o exame será realizado, avaliando-se o risco e o custo-benefício de cada caso.

\subsection{Esquemas CAD (Computer-Aided Diagnosis)}

No estudo dos mamogramas, qualquer desvio da normalidade deve ser analisado, mesmo que constitua em mera variação anatômica ou patologia sabidamente benigna. Todavia o grande objetivo da mamografia é a detecção de malignidade e seus sinais devem ser sistematicamente pesquisados. 
As limitações de ordem técnica dos mamógrafos já citadas neste capítulo e mamas de alta densidade, são as principais responsáveis pela taxa de falsos-negativos.

Com o intuito de minimizar os casos falsos-negativos, bem como os casos falsos-positivos, têm sido desenvolvidos sistemas CAD (de "Computer Aided Diagnosis"), visando auxiliar os radiologistas no diagnóstico, reduzindo o número desnecessário de biópsias, considerando que apenas de 10\% a 20\% dos casos enviados são comprovadamente malignos (Polkowski, 97).

Giger (2000) define o diagnóstico auxiliado por computador como aquele no qual o radiologista usa os resultados de uma análise computadorizada de imagens médicas como uma "segunda opinião" na detecção de lesões e na elaboração do diagnóstico. A importância desses esquemas é enfatizada por Chan et al. (1990), Doi et al. (1991), Giger; MacMahon (1996) e Petrick et al. (1996b), mostrando que o uso de esquemas CAD pode melhorar o desempenho de radiologistas no diagnóstico médico.

Pesquisas em CAD vêm sendo desenvolvidas em diversas áreas da radiologia, incluindo a do pulmão e tomografia computadorizada do tórax. A análise computadorizada para deteç̧ão de nódulos de pulmão e também de mamas, está baseada em detecção de bordas, realce de contraste e métodos baseados em processamento hierárquico com árvore de decisão. Alguns pesquisadores vêm utilizando também morfologia matemática em seus projetos, análise de fractais, redes neurais artificiais, wavelets, entre outras técnicas (Giger, 2000).

Os pesquisadores do Kurt Rossman Laboratories for Radiologic Image Research, na Universidade de Chicago, elaboraram um método computadorizado para a deteç̧ão de massas em mamogramas que é baseado nas diferenças de simetria entre as mamas consideradas normais (direita ou esquerda), sendo que as assimetrias correspondem a massas em potencial. O método envolve uma técnica não-linear de subtração bilateral que "destaca" assimetrias. Nessa técnica, eles mantiveram uma convenção de subtrair o lado direito do lado esquerdo (ESQ - DIR), evitando a criação de 2 
imagens processadas - uma na qual as massas em potencial fossem destacadas no lado esquerdo e outra na qual as possíveis massas fossem destacadas no lado direito. Técnicas de análise de características baseadas no tamanho, forma e contraste das possíveis massas foram utilizadas na análise de ambasas imagens (processadas e no mamograma original) com o objetivo de reduzir o número de falsos-positivos. Em um estudo preliminar com 154 pares de mamogramas (imagens do lado direito e esquerdo), o computador atingiu uma sensibilidade de $85 \%$ com 3 ou 4 detecções falso-positivas por imagem (Yarusso, 2000).

O Department of Radiology da University of Michigan desenvolveu um $C A D$ com o seguinte método: o mamograma digitalizado é processado com um filtro adaptativo, seguido de detecção de bordas e crescimento de região para detectar as estruturas da mama. São extraídas características morfológicas e de textura de cada estrutura detectada, que são usadas para identificar possíveis massas. O método de detecção foi desenvolvido e treinado com 253 mamogramas digitalizados. Nesse estudo, eles avaliaram a performance do algoritmo em mamogramas obtidos de 93 pacientes. Os casos foram separados em 2 conjuntos: "preoperativo" e "anteriores". O conjunto "preoperativo" continha 97 massas identificadas por um radiologista durante exames clínicos e posterior biópsia. O conjunto "anteriores" era constituído de 42 filmes destas mesmas pacientes obtidos entre 1 e 4 anos antes da biópsia. A sensibilidade do algoritmo foi medida caso a caso usando-se 2 vistas de cada mama.

O algoritmo computacional teve uma sensibilidade de detecção de $87 \%$ com 1,7 falsos -positivos por imagem para o conjunto "preoperativo", incluindose a detecção de $94 \%$ (46 em 49) das massas malignas. Para os conjuntos "anteriores", o algoritmo identificou $67 \%$ das massas com 2 falsos-positivos por imagem e uma sensibilidade de detecção de 73\% (19 em 26) para casos malignos (Petrick, 2000).

Nishikawa, et al (Nishikawa, 1999), desenvolveram um esquema CAD para análise de massas contidas em mamogramas digitalizados e imagens de 
ultra-som, distinguindo-as em lesões benignas e malignas. O método de classificação segue as seguintes etapas: identificação manual da massa, extração da lesão, extração automatizada de características e, por último, uma rede neural artificial para dar uma estimativa da probabilidade de malignidade. Foram executadas uma correção de fundo, equalização do histograma e um crescimento de região para extrair automaticamente a lesão do parênquima da mama nas imagens mamográficas. Para as imagens de ultra-som, um médico experiente delineou as margens das massas. Nas imagens mamográficas foram analisadas as seguintes características: grau de "espicularidade", nitidez da borda e textura da lesão. As características retiradas das imagens de ultrasom são as seguintes: definição da margem (normalização do gradiente radial), textura (baseado nos níveis de cinza) e formato. $O$ desempenho dos métodos distinguindo entre massas benignas e malignas foi analisado por curvas ROC.

Noventa e cinco mamogramas que continham massas de 65 pacientes foram digitalizados. O método de classificação resultou em um $A z=0,94$, semelhante a de um médico especialista $(A z=0,91)$ e significativamente mais alto que o desempenho de um radiologista comum $(A z=0,80)$.

Para um banco de dados que consistia em 201 imagens de ultra-som digitalizadas de 55 pacientes, onde as lesões malignas ou benignas foram confirmadas por biópsia e aspiração o classificador rendeu valores de $A z=0,80$.

Outros métodos de esquemas CAD são atualmente desenvolvidos para detectar lesões e nódulos em mamogramas digitais ou digitalizados. Inúmeras técnicas têm sido implementadas para segmentar estas lesões e destacar a borda. Dois destes métodos para segmentar massas são: o índice radial do gradiente ( $\mathrm{RGI}$ - Radial Gradient Index) - o algoritmo de base e algoritmo probabilístico. Estas técnicas têm como base o algoritmo de crescimento de regiões que demonstrou ser eficaz na segmentação e extração de bordas das massas. Este algoritmo começa com um ponto, chamado de ponto semente, definido por região suspeita através de outros algoritmos que retornam a localização destas regiões de forma probabilística e analisam os níveis de cinza e as características da vizinhança do pixel inicial. Foram detectadas 
aproximadamente $94 \%$ das lesões com o algoritmo desenvolvido (Kupinski, 1998).

Esquemas CAD vêm sendo desenvolvidos no Laboratório da Universidade de Chicago, para detectar nódulo em outros órgãos como o pulmão, por exemplo. O câncer de pulmão é um dos principais causadores de morte de homens e mulheres. A detecção e o diagnóstico precoce do câncer de pulmão são importantes fatores no aumento da taxa de sobrevida do paciente. A radiografia de tórax é considerada o mais prático exame para auxiliar o diagnóstico. Porém, erros na análise da imagem por parte do radiologista variam de $20 \%$ a $30 \%$ na detecção dos nódulos. Com o esquema CAD desenvolvido, a taxa de detecção verdadeira chega a 80\%, comprovado pelo laudo do exame complementar, a tomografia computadorizada. A técnica consiste em s ubtração de imagens para remover o fundo. Depois, utilizando a diferença dos níveis de cinza pelo histograma da imagem os possíveis nódulos são identificados e classificados em seis grupos de acordo com os níveis de threshold. Um algoritmo de crescimento de regiões é aplicado à imagem para segmentar os nódulos e análise do gradiente das bordas. Os aspectos da imagem derivados da técnica de crescimento de regiões incluem contraste, diâmetro, irregularidade de borda entre outras (Kobayashi, 1996).

As técnicas de análise e segmentação de imagens mamográficas de mamas densas apresentadas neste trabalho fazem parte de um conjunto de outras técnicas que deverão constituir um desses esquemas CAD.

\subsection{Dificuldades Encontradas na Visualização de Estruturas no Mamograma}

Os mamogramas constituem, há muito tempo, a principal fonte de dados para os esquemas CAD. Já em 1967, Winsberg et al. (1967) descreveram um procedimento para detectar anomalias em mamogramas através da análise computacional da densidade óptica do filme. No entanto, 
algumas características intrínsecas do processo mamográfico dificultam a construção desses esquemas. Alguns fatores físicos influenciam, gerando imagens mamográficas com baixa qualidade, causando essas dificuldades. Os detalhes e características dos mamogramas devem ser previstos de forma que seja possível estabelecer procedimentos automatizados para encontrar estruturas procuradas, segundo Ishida et al. (1984) e Dhawan (1988). Sickles (1982) afirma que esses detalhes e características variam bruscamente de equipamento para equipamento e dependem muito das especificações utilizadas quanto ao filme, posicionamento e outros aspectos que tornam impossível o estabelecimento de um procedimento global sem interação humana. A seguir, são apresentados alguns desses fatores.

\subsubsection{Dose Absorvida}

Como os raios -X constituem radiação ionizante e o excesso de radiação traz prejuízos ao organismo humano, é imprescindível um controle a fim de que a dose recebida pela paciente não seja mais prejudicial do que o benefício a que ela se propõe. Alguns fatores contribuem para o aumento da dose absorvida pela paciente, como o aumento da tensão e o aumento da corrente para a produção de fótons e ainda o prolongamento do tempo de exposição. Geralmente estas práticas são aplicadas quando se deseja uma imagem com intensidade mais acentuada (Curry III et al.,1990). Uma possível solução na redução da dose é a utilização de filtros- placas de metais posicionadas entre a fonte de raios- $X$ e o objeto a fim de absorver os fótons de energia baixa, deixando transmitir os fótons de energia alta que são os principais responsáveis pela formação da imagem efetiva (Scaff, 1979). Os metais constituintes e a espessura dessas placas variam de acordo com o nível de energia que se deseja absorver. Salienta-se que tal filtragem não influencia na formação da imagem, visto que os fótons eliminados, sendo de baixa energia, são totalmente absorvidos pelo organismo e não impressionam o filme, só contribuindo para aumento da dose. 
Com re lação a esta característica, as técnicas de processamento de imagens podem contribuir no sentido de realçar a imagem de acordo com a intensidade desejada, dispensando os costumeiros aumentos de tempo de exposição, tensão e/ou corrente de tubo (Ishida et al., 1983).

\subsubsection{Sobreposição de Objetos}

Este é um outro aspecto que exerce grande influência no reconhecimento de padrões, considerando que a imagem radiográfica é a representação bidimensional de um objeto tridimensional. Na mamografia o feixe de raios- $X$ é aplicado em diferentes incidências para gerar diferentes visões da mama. Dependendo do posicionamento das estruturas internas na mama, a imagem resultante pode apresentar sobreposição destes elementos, transformando dois ou mais objetos em um bloco único. Essa é uma limitação pouco abordada na literatura, mas, dependendo do tipo de processamento utilizado, objetos sobrepostos podem ser reconhecidos como únicos e, como conseqüência, levar a diagnósticos equivocados.

Uma possível solução é o processamento de mamogramas com visões diferentes, de forma que a localização de possíveis microcalcificações e o relacionamento entre suas localizações forneçam ao médico mais subsídios para o diagnóstico correto. Outra maneira de solucionar a questão seria o processamento e reconstrução de imagens tridimensionais.

\subsubsection{Contraste e Resolução Espacial}

O contraste em uma mamografia permite perceber diferenças na atenuação dos tecidos que compõem a mama. É o grau de variação da densidade ótica entre diferentes áreas da imagem ou entre uma anormalidade e os tecidos circunjacentes. $O$ aperfeiçoamento do contraste nos últimos anos deve-se ao tipo de filme, à qualidade da radiação, à exposição, ao processamento do filme e a redução da radiação secundária pela compressão 
e uso de grades nos aparelhos. Uma mamografia com bom contraste deverá apresentar grande diferença entre a densidade ótica e o tecido fibroglandular e da gordura. A gordura deverá ser de cinza escuro a preta do tecido glandular de cinza claro a branco (Eklung, 1994).

O ruído compromete a habilidade de discernir pequenos detalhes na mamografia, como microcalcificações e é maior em filmes de alto contraste.

Na imagem radiográfica o contraste refere -se à diferença de densidades entre áreas, conforme afirmam Dhawan et al. (1988), Curry III et al. (1990) e Xiong et al. (1993). Se o objeto cuja imagem está sendo registrada é formado por diferentes elementos e cada um desses elementos apresenta diferentes níveis de absorção dos fótons de raios $-\mathrm{X}$, então o padrão a ser registrado no filme apresentará diferentes intensidades. Quanto maior for a diferença entre as intensidades, maior será o contraste percebido e, provavelmente, maior facilidade oferecerá para interpretação médica.

Para que seja utilizado um esquema computadorizado para reconhecimento de estruturas em mamogramas, esses filmes precisam ser digitalizados. A digitalização é um processo que "lê" a imagem do filme e a transporta para o computador, tornando-a disponível para processamento. Os equipamentos utilizados para esse processo variam muito em termos de níveis de cinza oferecidos e resolução espacial.

Os níveis de cinza estão diretamente relacionados com o contraste. Geralmente uma faixa de densidades ópticas do filme é representada por um único nível de cinza na digitalização, como mostrado por Chan et al. (1987). A resolução espacial, por sua vez, refere-se à quantidade de pontos por unidade de medida que permite a maior ou menor percepção de detalhes na imagem. Em uma imagem digitalizada, refere-se à quantidade de pontos em um centímetro ou milímetro quadrado que, ao final, estabelecerá o tamanho da menor unidade da imagem digitalizada: o pixel. Karssemeijer et al. (1993) estudaram a influência da resolução espacial na mamografia, concluindo que este aspecto exerce grande influência na inspeção visual de especialistas, 
principalmente na definição da relação das estruturas analisadas com malignidade ou benignidade.

Esses dois aspectos devem ser muito bem observados para se ter um esquema eficiente. Os níveis de cinza vão ser processados a fim de informar o tamanho e localização da estrutura reconhecida.

A mamografia é o principal exame para detecção precoce do câncer de mama. No entanto, detectar nem sempre significa salvar a vida, mesmo detectando um tumor pequeno, já que este pode ser um câncer de crescimento rápido e agressivo e que já tenha se disseminado a outras partes do corpo antes de ser detectado. Sendo assim, as técnicas de processamento de imagens e os esquemas CAD têm o objetivo de auxiliar o diagnóstico, minimizando os fatores que coloquem em risco a paciente. 


\section{Capítulo 4 - Se gmentação de Imagens}

Segundo Beucher (Beucher, 1982), a segmentação é um processo complexo porque tenta traduzir para o computador um processo cognitivo extremamente sofisticado realizado através da visão humana. Segmentação de imagens não é o primeiro passo no entendimento da imagem estudada, mas uma conseqüência.

O princípio da segmentação foi introduzido no início do século XX por alguns psic ólogos alemães (Khler, Wertheimer e Kofftka) (Facon, 1993). Eles mostraram que o sistema de visão humana realiza agrupamentos baseados na proximidade, similaridade e continuidade das imagens captadas. Tais agrupamentos são utilizados na classificação e análise semântica dos objetos percebidos. Esta idéia foi estendida para o contexto computacional e deu origem aos primeiros algoritmos de segmentação de imagens.

Os algoritmos de segmentação para imagens são geralmente baseados em uma das seguintes propriedades básicas de valores de níveis de cinza: descontinuidade e similaridade. Na primeira categoria, a abordagem é particionar a imagem baseada em mudanças bruscas nos níveis de cinza. As principais abordagens da segunda categoria baseiam-se em limiarização, crescimento, divisão e fusão de regiões.

\subsection{A etapa crítica}

$\mathrm{Na}$ segmentação procura-se distinguir as partículas umas das outras e do fundo. Esta distinção permitirá ao programa computacional interpretar pixels contíguos e agrupá-los em regiões. Esta etapa é a mais difícil do processo e também a mais delicada porque todas as medidas serão realizadas sobre as regiões identificadas. 
Adquirida a imagem e definida a forma com que será apresentada e armazenada, será realizado o processamento propriamente dito, executando toda a gama de operações e algoritmos possíveis de acordo com a necessidade.

$\mathrm{Na}$ maioria das aplicações, depois de adquirida e armazenada a imagem original, são utilizadas técnicas de segmentação de imagem (separação da imagem em regiões que tenham algum significado) e depois técnicas de análise (identificação e classificação destas regiões). Finalmente, são apresentados os resultados obtidos por esses processos.

\subsection{Aquisição de Imagens Digitais}

O processo de aquisição de imagens é uma das ? ou talvez a ? mais importante etapa num esquema CAD, quando a imagem é convertida numa representação numérica adequada para o processamento digital. É nesta etapa que se definem fatores como as taxas de resolução (tanto espacial como de contraste).

A etapa de aquisição compreende dois elementos principais: O Sensor e o Digitalizador.

\subsubsection{Sensores}

O sensor é um dispositivo físico sensível a uma faixa de energia no espectro eletromagnético (como raios- $X$, ultravioleta, espectro visível ou raios infravermelhos), que produz na saída um sinal elétrico proporcional ao nível de energia detectado (Marques, 1999).

Como exemplo, consideremos os aspectos básicos de um sistema de imageamento de mama por raios-X. A saída de uma fonte de raios-X é direcionada para uma mama e um meio sensível a raios $-X$ é colocado do outro lado da mesma. $O$ meio adquire assim uma imagem dos materiais que 
compõem a mama (tais como tecidos ou estruturas de interesse), que possuam graus diferentes de absorção de raios $-X$. O meio pode s er um filme, uma câmera de televisão combinada com um conversor de raios $-X$ para fótons ou detectores discretos, cujas saídas sejam combinadas para a reconstrução de uma imagem digital (Gonzalez, 1992).

\subsubsection{Digitalização}

Existem basicamente duas maneiras de se obter um mamograma digital. A primeira é a digitalização do filme mamográfico através de um scanner (convencional ou específico para filmes). A segunda é através da utilização de mamógrafos digitais, que possuem no lugar do filme, dispositivos sensíveis aos raios-X que, juntamente com um conversor analógico/digital, transformam os fótons recebidos em informações digitais.

O digitalizador ou conversor analógico digital (conversor $A / D$ ), é um dispositivo para a conversão da saída elétrica (sinal analógico) de um dispositivo de sensoriamento físico para a forma digital de forma que esta informação possa ser representada de forma binária, através de bits 0s e 1s e assim interpretada pelo computador.

No processo de conversão, o sinal analógico é mostrado em uma matriz de $\mathrm{M}$ por $\mathrm{N}$ pontos, cada qual denominado pixel (ou elemento de imagem):

Tabela 41 - Exemplificação da matriz de pixels de uma imagem.

$$
f(x, y)=\left[\begin{array}{cccc}
f(0,0) & f(0,1) & \ldots & f(0, N-1) \\
f(1,0) & f(1,1) & \ldots & f(1, N-1) \\
f(2,0) & f(2,1) & \ldots & f(2, N-1) \\
\vdots & \vdots & \vdots & \vdots \\
f(M-1,0) & f(M-1,1) & \Sigma & f(M-1, N-1)
\end{array}\right]
$$

Maiores valores de $\mathrm{M}$ e $\mathrm{N}$ implicam em uma imagem de maior resolução. Além da forma $\mathrm{M} \times \mathrm{N}$ (linhas por colunas da imagem), a resolução espacial de uma imagem pode ser apresentada na forma de DPIs (pontos por 
polegada), ou seja, este tipo de informação indica quantos pixels são usados para representar cada polegada $(2,54 \mathrm{~cm})$ da imagem original. Ou ainda pode se utilizar o tamanho do pixel (em milímetros) para se indicar a resolução da imagem digitalizada

A quantização faz com que cada um destes pixels assuma um valor inteiro, na faixa de 0 a $2^{n}-1$. Quanto maior o valor de $n$, maior o número de níveis de cinza presentes na imagem digitalizada.

$\mathrm{Na}$ especificação do processo de digitalização, deve-se decidir que valores de $\mathrm{N}, \mathrm{M}$ e $\mathrm{n}$ são adequados, do ponto de vista de qualidade da imagem e da quantidade de bytes necessários para armazená-lo. Do ponto de vista qualitativo, é obvio que quanto maior os valores de $\mathrm{M}, \mathrm{N}$ e $\mathrm{n}$, melhor será a qualidade da imagem digitalizada. No entanto, quanto maior os valores de $\mathrm{M}$, $\mathrm{N}$ e n, maiores serão os custos de digitalização e armazenamento. Portanto, para se definir tais valores deve se levar em conta os fins para os quais a imagem está sendo digitalizada.

Para digitalização de um mamograma, os valores da resolução espacial e também da quantização a serem empregados devem estar diretamente relacionados com as características do filme e das estruturas pesquisadas (Russ, 1992).

\subsubsection{Digitalizadores}

Os digitalizadores são equipamentos destinados à digitalização de imagens, utilizando para isso uma fonte emissora de luz que é direcionada para a imagem e um sensor que capta a luz refletida (caso a imagem em questão seja na forma de fotografia) ou transmitida (caso a imagem esteja gravada em um filme como nos mamogramas).

Vários autores indicam os digitalizadores com uma fonte de luz a laser para a digitalização de filmes como sendo o dispositivo mais eficiente para a 
aquisição de filmes radiográficos, devido à qualidade da imagem e às altas taxas de resolução alcançadas por estes sistemas.

\subsection{Técnicas de Segmentação de Imagens}

Serão apresentadas algumas técnicas de segmentação de imagens implementadas computacionalmente e que, segundo a literatura, apresentam bons resultados dependendo do problema a ser resolvido.

\subsubsection{Limiarização - A Intensidade Como Separador}

A imagem de um objeto pode ser entendida como uma região formada por pixels contíguos que tenham em comum uma faixa de intensidades (Paciornik, 2001). O processo se baseia na análise do histograma da imagem, que é um gráfico que mostra o número de pontos de uma imagem que tem o mesmo tom de cinza. $\mathrm{Na}$ abscissa temos os níveis de cinza enquanto na ordenada temos a quantidade de pontos. Uma imagem digitalizada não colorida consiste de vários tons de cinza (ou no mínimo 2 tons, se for preto e branco).

Uma imagem digitalizada pode ser representada por uma matriz. Cada ponto da matriz representa um ponto da imagem e contém o valor do tom de cinza desse ponto, ou seja, a intensidade luminosa do ponto.

A técnica de limiarização não funciona bem em imagens com iluminação não uniforme e com baixo contraste entre as diversas regiões.

Existem processos manuais e automáticos. Métodos automáticos baseiam-se na análise de propriedades do histograma e utilizam os mínimos do histograma que correspondem às tonalidades intermediárias entre duas bandas. Em geral o operador escolhe a tonalidade próxima à banda de interesse, e o programa busca os mínimos mais próximos, em ambos os lados da banda. 
Basicamente todos os pixels que estão dentro de uma faixa de intensidade são classificados como pertencentes a uma mesma região. Em sua forma mais geral a limiarização pode ser descrita matematicamente como: $S(i, j)=k$ se $T_{k-1} \leq f(i, j)<T_{k}$ para $k=1,2, \ldots, m$ onde $S(i, j)$ é a função

resultante, $f(i, j)$ é a função original (imagem), $T_{0}, \ldots, T_{m}$ são os valores de limiarização (thresholding) e $m$ é o número de classes distintas a serem aplicadas à imagem.

Se $m=1$, o método de limiarização é denominado limiarização binária. Se, por outro lado, $m>1$, o método é descrito como limiarização multi-modal.

Existem dois problemas: os vales podem ser muito largos e planos, tornando a escolha de um valor mínimo arbitrária e os vales podem assumir valores muito baixos, ficando muito sensíveis a ruído.

Limiarização adaptativa: subdivide a imagem, aplica uma limiarização a cada subdivisão, obtendo assim vários tons de corte. Em seguida, interpola os tons de corte obtidos para as subdivisões para obter um tom de corte para cada pixel da imagem.

As vantagens da técnica são a menor sensibilidade à irregularidade de fundo e as variações locais. A lentidão do processo vem a ser a sua principal desvantagem.

\subsubsection{Métodos Baseados nos Contornos dos Objetos}

Os métodos de segmentação baseados na deteç̧ão de bordas envolvem basicamente a localização de regiões da imagem onde a variação dos tons de cinza ocorre de maneira relativamente abrupta. As descontinuidades, como são chamadas, podem ocorrer na forma de pontos isolados, linhas, segmentos ou curvas e, a partir delas, são formados os contornos, ou bordas, dos objetos contidos na imagem (Marques, 1992). 
De fato, a existência de tais descontinuidades é característica de um conjunto limitado de imagens. Em muitas delas, a transição de uma região para outra ocorre de maneira tão sutil que tornam a aplicação dos métodos de detecção de borda uma opção inviável.

Após a detecção das descontinuidades segue-se, geralmente, a aplicação de algum método capaz de conectar tais fragmentos e gerar contornos que estejam associados com os contornos reais dos objetos.

Um objeto pode ser entendido como uma região dentro de um contorno. Para distinguí-lo, detecta-se as bordas e tenta-se construir um contorno a partir delas.

Este modelo é muito mais custoso computacionalmente, mas simula o comportamento do olho humano, e é muito flexível e genérico.

A extração de bordas é realizada por um algoritmo de detecção de bordas que considera os gradientes de nível de cinza da imagem original, para gerar uma imagem gradiente ou imagem de intensidade de borda.

O algoritmo calcula um limiar para a perseguição de bordas. Quando ele encontra um "pixel" com valor superior ao limiar estabelecido, tem-se início o processo de perseguição da borda. Observa-se a vizinhança para identificar o próximo "pixel" de maior valor de nível digital e segue-se nesta direção até que se encontre outra borda ou a fronteira da imagem. Deste processo gera-se uma imagem binária com os valores de 1 referentes às bordas e 0 , a regiões de não-bordas.

A imagem binária será rotulada de modo que as porções da imagem com valores 0 constituirão regiões limitadas pelos valores 1 da imagem, constituindo a imagem rotulada. 


\subsubsection{Crescimento de Regiões}

Define-se região como um conjunto conexo de pontos com uma propriedade em comum. A imagem é a soma de todas as regiões. Este conjunto de "pixels" contíguo se espalha bidirecionalmente e apresenta uniformidade.

É uma técnica de agrupamento de dados, na qual somente as regiões adjacentes, espacialmente, podem ser agrupadas.

A partir de um conjunto inicial de pontos (sementes), agrega-se a cada um deles novos pixels vizinhos que contenham propriedades similares, tais como cor, textura ou nível de cinza.

Inicialmente, este processo de segmentação rotula cada "pixel" como uma região distinta. Calcula-se um critério de similaridade para cada par de regiões adjacentes espacialmente. $O$ critério de similaridade baseia-se em um teste de hipótese estatístico que testa a média entre as regiões. A seguir, divide-se a imagem em um conjunto de sub-imagens e então se realiza a união entre elas, segundo um limiar de agregação definido.

Para a união de duas regiões A e B vizinhas, deve-se adotar o seguinte critério:

$\Rightarrow A$ e $B$ são similares (teste das médias);

$\Rightarrow$ A similaridade satisfaz o limiar estabelecido;

$\Rightarrow A$ e $B$ são mutuamente próximas (dentre os vizinhos de $A, B$ é a mais próxima, e dentre os vizinhos de $B$, A é a mais próxima).

Caso as regiões $A$ e $B$ satisfaçam estes critérios, estas regiões são agregadas, caso contrário o sistema reinicia o processo de teste de agregação. Um exemplo da técnica é mostrado na Figura 4-1. 

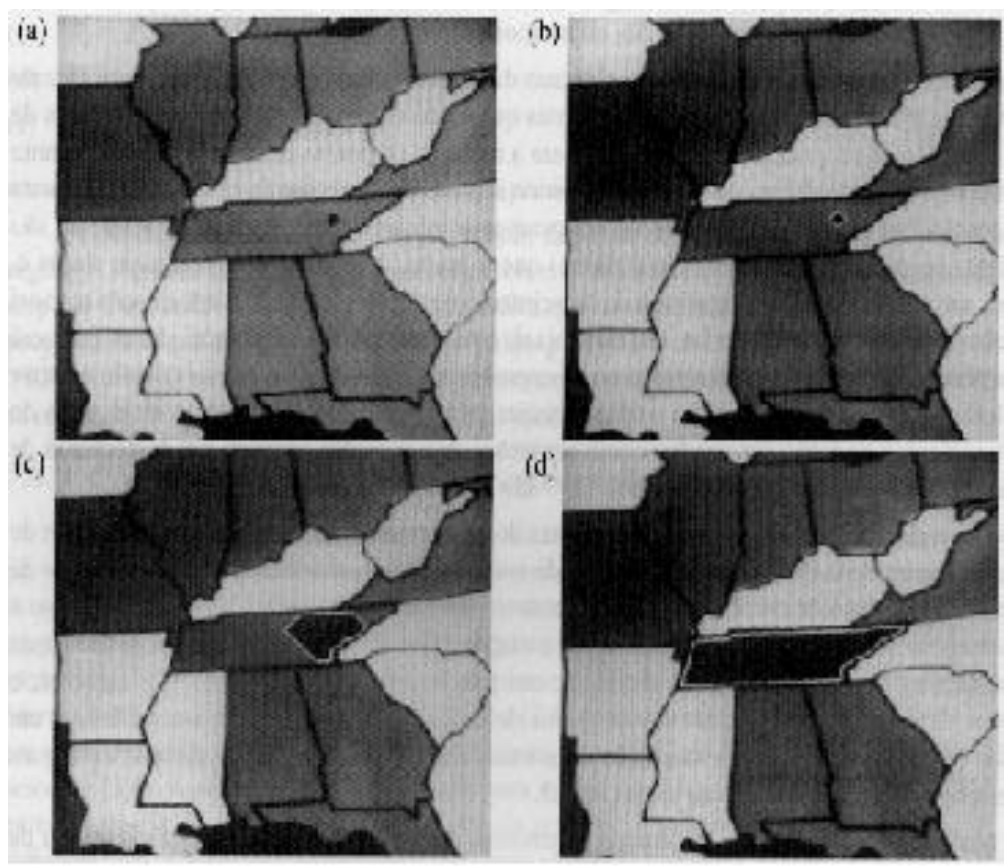

Figura 4-1 - Segmentação de imagem utilizando a técnica de crescimento de regiões. (Gonzalez,1992) (a) Imagem original mostrando um ponto semente; (b) estágio primário de crescimento de região; (c) estágio intermediário de crescimento de região; (d) região final

\subsubsection{Morfologia Matemática}

Morfologia matemática é uma ferramenta para extrair da imagem, componentes úteis para representaçãoe descrição do formato de objetos. Do ponto de vista prático, esta técnica encontra aplicações na maioria das tarefas de processamento de imagens: restauração, segmentação, extração de medidas, etc.

Nos métodos morfológicos, as imagens são analisadas em termos de forma e tamanho utilizando padrões elementares denominados elementos estruturantes.

O elemento estruturante vai interagir com cada entidade contida na imagem em estudo, modificando a sua forma, o seu tamanho, permitindo assim tirar algumas conclusões desejadas. Ou seja, o elemento estruturante é um conjunto completamente definido e conhecido (tamanho e forma), que é comparado, a partir de uma transformação, ao conjunto desconhecido da 
imagem. O resultado dessa transformação permite avaliar o conjunto desconhecido.

A eficiência e também a dificuldade da morfologia matemática reside na escolha da deformação certa para transformar a intuição intelectual em aplicação prática.

A linguagem para morfologia matemática é teoria dos conjuntos, onde os conjuntos representam os formatos dos objetos em uma imagem.

Dentre as várias técnicas de morfologia matemática, a técnica de Watershed será utilizada neste trabalho, bem como as demais técnicas descritas anteriormente, adaptadas para a melhor implementação do sistema proposto.

\subsection{Segmentação Usando o Algoritmo Watershed}

O conceito da transformada Watershed foi originalmente proposto por Digabel e Lantuéjoul (Digabel, 1978) e posteriormente elaborado por Beucher e Lantuéjoul (Beucher, 1979). A idéia básica desta técnica consiste em observar uma imagem digital em tons de cinza como se ela fosse uma superfície montanhosa, sendo que a altitude de cada ponto está diretamente relacionada ao nível de cinza do pixel correspondente. Uma gota de água que cair sobre esta superfície irá percorrer o caminho mais íngreme até chegar a uma região de mínimo. $O$ conjunto de todos os pontos (pixels) para os quais uma gota de água que cai e converge para a mesma região de mínimo é chamada represa (catchment basin). Porém, para alguns pontos não é possível determinar para onde irá escorrer a gota de água que ali cair. $O$ conjunto destes pixels formam as fronteiras das represas e são denominados divisores de água (Watershed), como ilustrado na Figura 4-2. 


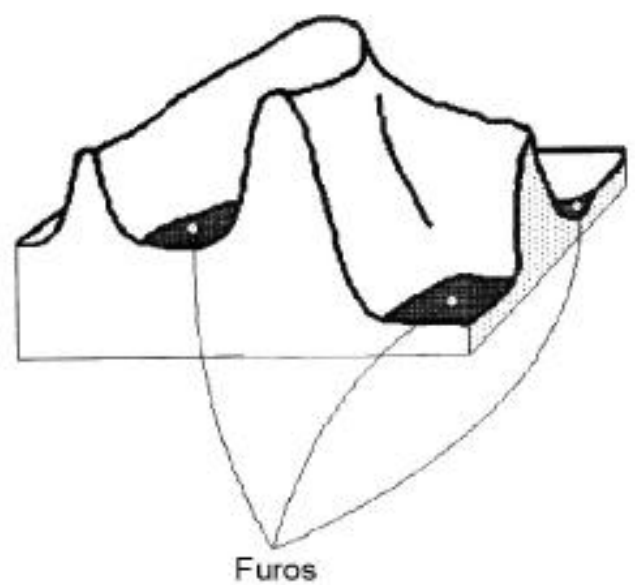

Figura 42- Ilustração da topografia com os pontos de mínimo.

A transformada Watershed é normalmente aplicada sobre a transformada gradiente de uma imagem. Isto porque os contornos da imagem serão reforçados após a aplicação do gradiente, tornando mais fácil o processo de segmentação.

Sendo assim, serão apresentadas a seguir, algumas das funções utilizadas nas etapas de aplicação da transformada.

\subsubsection{O Gradiente Morfológico}

O gradiente morfológico de uma imagem é um operador utilizado geralmente para obter o contorno de objetos em figuras binárias e realçar o contorno de objetos em figuras em tons de cinza e é definido por:

$$
g(f)=(f \oplus B)-(f O B)
$$

Onde:

$g(f)$ = função gradiente 
$(f \oplus B)=$ dilatação da imagem original

$(f \quad O B)=$ erosão da imagem original

O gradiente é o vetor que indica a direção de maior crescimento em qualquer ponto no domínio da mesma. Para uma função bidimensional (uma imagem, por exemplo), o gradiente é definido da seguinte maneira:

$$
G[f(x, y)]=\left[\begin{array}{l}
G_{x} \\
G_{y}
\end{array}\right]=\left[\begin{array}{l}
\frac{\partial f}{\partial x} \\
\frac{\partial f}{\partial y}
\end{array}\right]
$$

\subsubsection{Gradiente Interno e Externo}

Há algumas diferenças entre os dois tipos de gradientes de bordas de uma região (Rivest, 1992), ambos estão exemplificados na Figura 4-3.

O gradiente interno ${ }^{g^{-}}$é definido pela diferença entre a imagem original e a erosão desta imagem e realça as bordas dos objetos da imagem:

$$
g^{-}(f)=f-\epsilon_{B}(f)
$$

O gradiente externo $g^{+}$é definido como a diferença da dilatação da imagem e a imagem original e é geralmente aplicado à estruturas escuras:

$$
g^{+}(f)=\delta_{B}(f)-f
$$

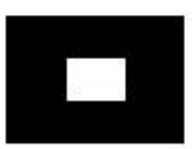

$\mathrm{X}$

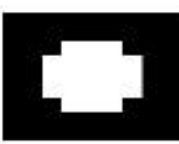

$\mathrm{X}$ dil $\mathbf{B}$

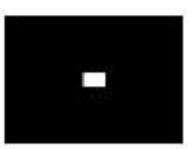

$\mathrm{X}$ ero $\mathbf{B}$

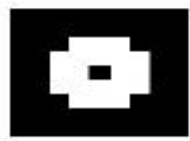

$\operatorname{grad}(\mathrm{X})$

Figura 4-3 - Exemplo de imagem original, imagem dilatada, erodida e o gradiente desta imagem. 


\subsubsection{A Transformada da Distância:}

A transformada da Distância mapeia uma imagem binária em uma imagem em tons de cinza, de modo que, o to $m$ de cinza de um pixel $p$ na imagem resultante é proporcional à menor distância do ponto $p$ na imagem binária ao background da mesma.

\subsubsection{Operador Hit-and-Miss}

Este operador morfológico é utilizado basicamente para localizar padrões dentro de uma figura. Ele utiliza um novo tipo de elemento estruturante que possui 3 estados: '0', '1', e 'não importa', como mostrado na Figura 4-4.

Exemplo:

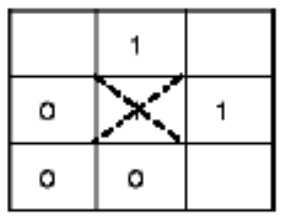

Figura 4-4-Elemento estruturante com três estados

As posições do elemento estruturante que não possuem valores (estado 'não importa'), não são levadas em consideração na comparação com os pixels da imagem.

Algoritmo: "encaixar" o elemento estruturante em cada pixel da imagem. Definir como pixels do primeiro plano da imagem os pixels onde o elemento estruturante se encaixa perfeitamente. Como exemplificado nas Figuras 4-5 e 4-6.
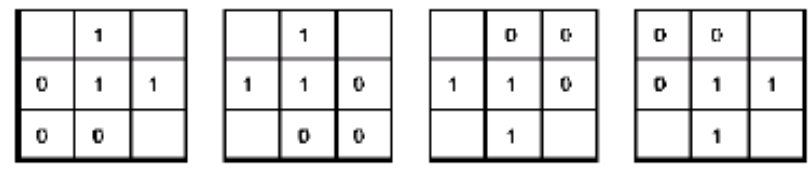

Figura 4-5 - elementos estruturantes utilizados para detecção de vértices 


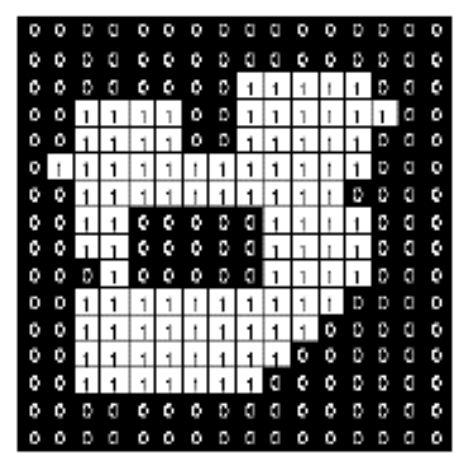

Imagem original

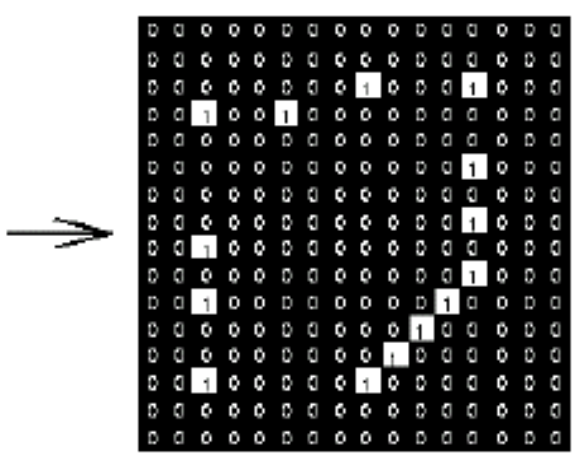

Vértices detectados

Figura 4-6 - detecção dos vértices de um objeto utilizando thining

\subsubsection{Thining}

O operador Thining é uma aplicação direta do operador Hit-and-Miss. Ele é um operador morfológico utilizado para remover pixels do primeiro plano da imagem que satisfazem exatamente o padrão dado pelo elemento estruturante utilizado.

$O$ thining de uma imagem $X$ pelo elemento estruturante $B$, é na verdade a subtração da operação hit-and-miss (X, B), da imagem original X. É possível, entretanto, optar por uma implementação direta do operador através do algoritmo abaixo:

$\Rightarrow$ "encaixar" o elemento estruturante em um pixel da imagem;

$\Rightarrow$ Se o elemento se encaixa perfeitamente em tal posição, então definir o pixel como pertencente ao background, senão, não alterar o pixel;

$\Rightarrow$ Repetir os passos anteriores para todos os pixels da figura.

O thining é quase sempre utilizado de maneira seqüencial, ou seja, aplicando-se várias vezes o operador com diferentes elementos estruturantes. 
Seja então o conjunto de elementos estruturantes (B1, B2, ... , Bn). O thining seqüencial é definido como: thin $\left(X,\left\{B_{1}\right\}\right)=$ thin $($ thin $(X, B 1),(B 2) \ldots B n)$

Há várias seqüências úteis de elementos estruturantes para serem utilizadas com o thining seqüencial. Tais seqüências são freqüentemente denominadas Golay Alphabet.

Uma das seqüências mais importante é a seqüência L. Esta seqüência apresenta a peculiaridade de poder reduzir um objeto na imagem, através da aplicação seqüencial do operador thining, a um novo objeto que diz respeito apenas à forma do objeto anterior: seu esqueleto.

\subsubsection{Esqueleto por zona de influência ( $S K I Z)$ :}

Esqueletização é o processo de redução do primeiro plano da imagem em uma estrutura que preserve a forma e a conectividade da região, tornandoa mais propícia para determinadas operações.

A idéia de esqueleto foi apresentada por Blum com o nome de "transformação do eixo medial" (medial axis transformation) e é ilustrada da seguinte maneira: suponha que uma região (um conjunto de pontos) $X \subset R^{2}$ seja um gramado. Se atearmos fogo em toda região da borda deste objeto ao mesmo tempo e a propagação do fogo for uniforme e de velocidade constante, o esqueleto $S(X)$ deste objeto será o conjunto de todos os pontos onde duas ou mais fontes de fogo se encontram. A Figura 4-7 ilustra tal situação.

Uma definição mais formal de esqueleto é baseado no conceito de "bolas maximais". Uma bola $B(p, r)$ com centro p e raio $r(r .0)$ é o conjunto de pontos com distâncias $d$ do centro menores ou iguais a $r$.

Uma bola $B$ inclusa num conjunto $X$ é dita maximal se, e somente se, não há nenhuma outra bola em $X$ que contenha $B$. 


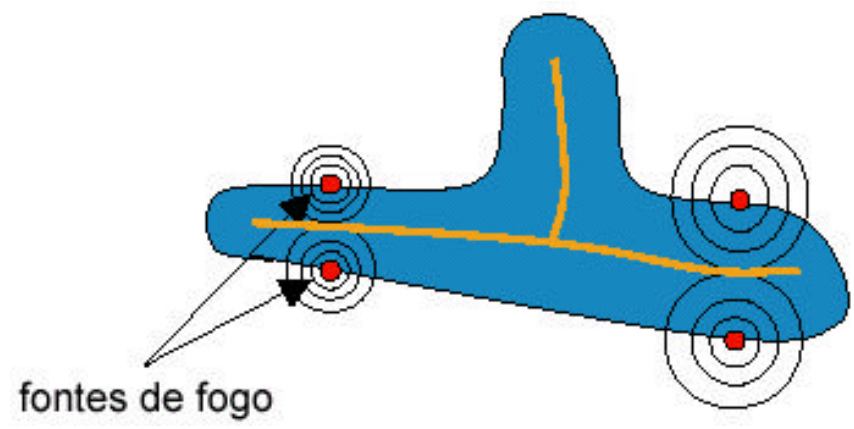

Figura 4-7 - definição informal de esqueleto (fontes de fogo ao longo da fronteira do objeto)

O esqueleto por bolas maximais $S(X)$ de um objeto é então o conjunto dos centros de todas as bolas maximais dele, como ilustrado na figura 4-8.

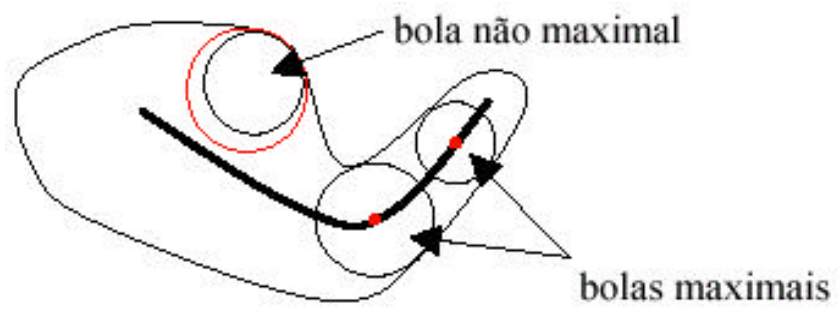

Figura 48 - definição formal de esqueleto através do conceito de bolas maximais

O SIKIZ é uma estrutura que divide uma imagem em regiões, cada qual contendo um objeto distinto. Ele também é conhecido como diagrama de Voronoi. O SKIZ (Figura 49), pode ser encontrado através do operador thickening da seguinte forma:

$\Rightarrow$ Determinar o esqueleto do background (thining seqüencial com 0 conjunto de elementos $\mathrm{L}$ - operação correspondente a um thickening no primeiro plano da imagem);

$\Rightarrow$ Podar o esqueleto de modo que somente as linhas cíclicas permaneçam (thining). 


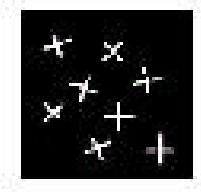

Inagetn criginal

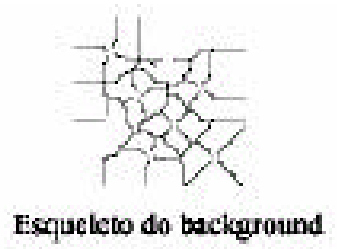

Foqueleto do background

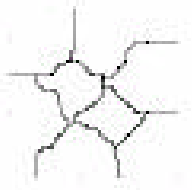

SKIZ

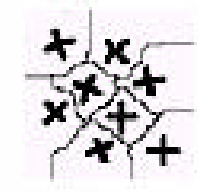

Imagess solkcpostas

Figura 4-9 - Determinação do Skiz de uma imagem

A função da distância: $S K I Z$ (skeleton by influence zones). Tenha $X \subset Z^{2}$, sendo $\mathrm{x}$ e $\mathrm{y}$ dois pontos de $X$, podemos definir a distância geodésica $d_{x(x, y)}$ entre $\mathrm{x}$ e $\mathrm{y}$ como o menor caminho entre os pontos inclusos em $\mathrm{X}$ ligando $x$ e $y$.

\subsubsection{Análise dos Pontos de Mínimo e Máximo}

Mínimo e máximo da função: análise de todos os pontos $\{x, f(x)\}$ em $Z^{2} X Z$ entendida como a superfície topográfica $S$. O nível de cinza mais brilhante do ponto $x$ tem valor $f$ e é o ponto mais alto da superfície. $O$ mínimo de $\mathrm{f}$, chamado de mínimo regional é definido, considerando dois pontos, $\mathrm{S} 1$ e S2 da superfície S. No caminho entre $S_{1}\left(x_{1}, f\left(x_{1}\right)\right)$ e $S_{2}\left(x_{2}, f\left(x_{2}\right)\right)$ é uma seqüência $\left\{S_{i}\right\}$ de pontos de S, com ${ }^{S_{i}}$ adjacente para $S_{i-1}$. O mínimo pode ser considerado como uma bacia da superfície topográfica. Tendo $m(f)$ de todos os pontos de mínimo de ${ }^{f}$ e seus vários componentes conectados $m_{i}(f)$.

Watershed é uma poderosa ferramenta de segmentação de imagens baseada na teoria de Morfologia Matemática, que consiste em associar a uma região as suas condições de contorno. 
A idéia original é a "gota" cair e deslizar até o ponto de mínimo, no entanto, o inverso da transformada pode ser descrito imaginando a imagem $f$ como uma superfície topográfica. Imagine também que seja feito um furo em cada ponto de mínimo local $m_{i}(f)$ da superfície, e então esta fosse mergulhada em um recipiente com água a uma velocidade vertical constante. A água entraria através dos furos e durante a imersão duas ou mais bacias com diferentes pontos de mínimo poderiam se unir. Para evitar este evento, diques são construídos sobre os pontos da superfície onde a água poderia unir-se. No final do processo, esses diques definem as linhas de Watershed da imagem $f$, ou seja, as bacias retentoras de água $\mathrm{CBi}(\mathrm{f})$ foram separadas, e cada uma possui um único ponto de mínimo. O Watershed sempre gera contornos fechados e constitui uma abordagem geral da detecção de contornos.

Considere a secção $Z_{i}(f)$, e suponha que a água a tenha enchido. Considere agora a secção $Z_{i+1}(f)$. Pode-se ver que $Z_{i+1}(f)$ é formado de zonas de influência de componentes conectados de $Z_{i}(f)$ em $Z_{i+1}(f)$. Alguns componentes conectados de $Z_{i+1}(f)$, os quais não estavam conectados em $Z_{i}(f)$, são por definição mínimos do nível i+1. Então denotamos por $W_{i} f$ a secção no nível i da bacia de retenção para f, e $m_{i}(f)$ o mínimo da função para a altura $\mathrm{i}+1$. Assim temos:

$$
W_{i+1}(f)=\left\lfloor I Z_{Z_{i+1}(f)}\left(X_{i}(f)\right)\right\rfloor \cup m_{i}(f)
$$

O mínimo do nível i+1 é dado por:

$$
m_{i+1}(f)=Z_{i+1}(f) / R_{Z_{i+1}(f)}\left(Z_{i}(f)\right)
$$

Este algoritmo é inicializado com $W_{-1}=0$. No final do processo as linhas de Watershed DL(f) são iguais a:

$$
D L(f)=W_{N}^{c}(f)
$$


Onde $\max (f)=N$.

O método de obtenção de marcadores ("furos"), varia de acordo com o tipo de imagem a ser segmentada. Existem inúmeros métodos de obtenção de marcadores devido ao fato de que a segmentação em cada imagem é um problema específico.

Um dos métodos mais simples para obtenção de marcadores de Watershed é pelo Threshold da imagem. Sobre a imagem binária é aplicada uma abertura morfológica seguida de distância morfológica. Sobre a imagem da distância aplica-se o operador de máximo regional. No inverso da distância é aplicado o operador de Watershed utilizando-se da imagem do máximo regional como marcador, como mostrado na Figura 4-10.
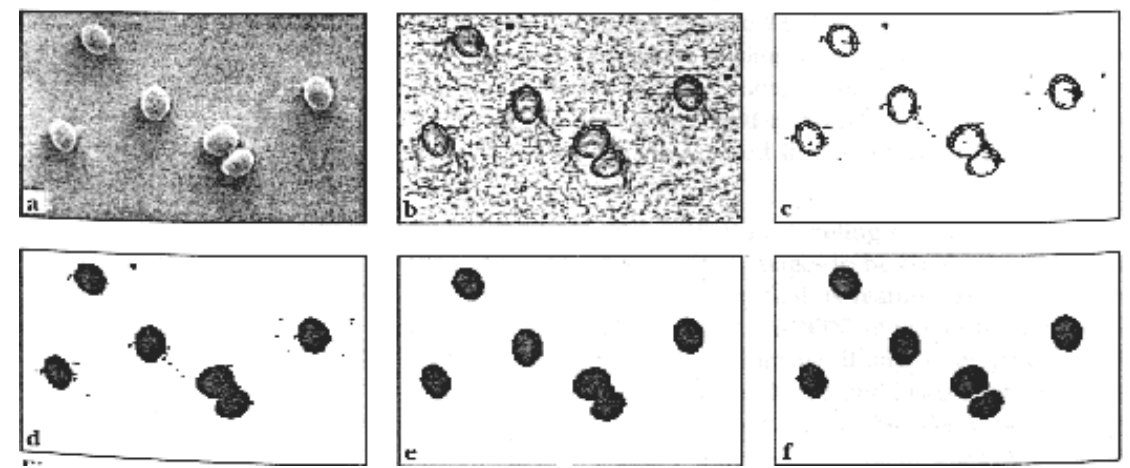

Figura 4-10 (a) Imagem original de grãos; (b) Imagem dos Marcadores; (c) Imagem Segmentada por Watershed; (d) Imagem Dilatada; (e) Imagem Erodida; (f) Imagem Final. (MARQUES, 1992)

\subsubsection{Algoritmo Clássico de Imersão}

Uma definição algorítmica da transformada de Watershed foi proposta por Vincent e Soile (Vincent; 1991). Seja f uma imagem digital em tons de cinza com $h_{\min } \mathrm{e}^{h_{\max }}$ sendo, respectivamente, os valores mínimos e máximo que um pixel da imagem pode assumir. Define-se uma recursão com o nível de cinza $h$ aumentando de $h_{\min }$ a $h_{\max }$, na qual as represas associadas com regiões de mínimo de f são sucessivamente expandidas. Seja $X_{h}$ a união de todas as represas computadas no nível h. Um componente conexo do conjunto 
de threshold $T_{h+1}$ no nível $\mathrm{h}+1$ pode tanto ser uma nova região de mínimo quanto uma extensão de uma represa pertencente a $X_{h}$. No último caso, computar a zona de influência geodésica (Roerdink, 2000) de ${ }^{X_{h}}$ com relação ao conjunto $T_{h+1}\left(I Z_{T_{h+1}}\left(X_{h}\right)\right)$, resultando em uma atualização $X_{h+1}$.

Seja $M I N_{H}$ a união de todas as regiões de mínimo para o nível h.

$$
\left\{\begin{array}{c}
X_{h_{\min }}=\left\{p \in D \mid f(p)=h_{\min }\right\}=T_{h_{\min }} \\
X_{h+1}=\operatorname{MIN}_{h+1} \cup I Z_{T_{h+1}}\left(X_{h}\right), h \in\left[h_{\min }, h_{\max }\right]
\end{array}\right.
$$

A transformada de wshed $(f)$ de f é o complemento de $X_{h+1}$ sob o domínio da imagem $\mathrm{D}$ :

$$
\text { wshed }(f)=D \backslash X_{h_{\max }}
$$

Para um exemplo da recorrência citada acima, veja figura 4-11. Neste exemplo, A e B são utilizados para denotar represas (regiões) distintas, e W para denotar as linhas divisórias (Watersheds). A Figura 4-11(a) ilustra a imagem original em tons de cinza. A recursão ocorre do nível $h_{\min }=0$ ao nível $h_{\max }=3$. Para $h=0, X_{h}$ é a união de todas as regiões conexas com intensidade igual a zero $\left(T_{h_{\min }}\right)$. Observa-se então a criação de duas regiões distintas $A$ e $B$. No segundo passo $(h=1)$, a zona de influência geodésica é calculada para os subconjuntos A e B sob o conjunto $T_{h+1}=T_{2}$ (conjunto de todos os pontos com intensidade menor ou igual a dois). Alguns pontos estão eqüidistantes de $\mathrm{A}$ e de $\mathrm{B}$, portanto são demarcados provisoriamente como W. Os demais são agregados à região mais próxima, como é o caso do pixel logo acima de B na Figura 4-11(b). O resultado deste passo é a Figura 4-11(c). No passo seguinte, novamente calcula-se $I Z_{T_{h+1}}\left(X_{h}\right)$ para $\mathrm{h}=2$, resultando na Figura 4-11(d). Nota-se que o pixel central da imagem, que no passo anterior fora denominado W, passa a fazer parte da região B. Por fim, a Figura 4-11(e) 
ilustra o resultado final da segmentação. Os pontos das regiões A e B formam o conjunto $X_{h_{\max }}$. A transformada de Watershed, conforme mencionado, é o complemento desde conjunto sob o domínio da imagem, ou seja, todos os pontos da imagem rotulados $\mathrm{W}$.

\begin{tabular}{|l|l|l|}
\hline 3 & 2 & 2 \\
\hline 3 & 1 & 1 \\
\hline 0 & 1 & 0 \\
\hline
\end{tabular}

(a)

\begin{tabular}{|l|l|l|}
\hline 3 & 2 & 2 \\
\hline 3 & 1 & 1 \\
\hline $\mathbf{A}$ & 1 & $\mathbf{B}$ \\
\hline
\end{tabular}

(b) $h=0$

\begin{tabular}{l|l|l|}
\hline 3 & 2 & 2 \\
\hline 3 & $W$ & $B$ \\
\hline $\mathbf{A}$ & $W$ & $B$ \\
\hline
\end{tabular}

(c) $h=1$

\begin{tabular}{|l|l|l|}
\hline 3 & $\mathbf{B}$ & $\mathbf{B}$ \\
\hline 3 & $\mathbf{B}$ & $\mathbf{B}$ \\
\hline $\mathbf{A}$ & $\mathbf{W}$ & $\mathbf{B}$ \\
\hline
\end{tabular}

(d) $\mathrm{h}=2$

\begin{tabular}{|l|l|l|}
\hline $\mathbf{B}$ & $\mathbf{B}$ & $\mathbf{B}$ \\
\hline W & $\mathbf{B}$ & $\mathbf{B}$ \\
\hline $\mathbf{A}$ & $\mathbf{W}$ & $\mathbf{B}$ \\
\hline
\end{tabular}

(e) $h=3$

Figura 4-11: Ilustração do algoritmo de imersão. (a) imagem original; (b-e) passos de rotulação.

Não existe um modelo formal para a segmentação. O processo é essencialmente empírico e deverá ajustar-se a diferentes tipos de imagem. Será apresentada no próximo capítulo a implementação da transformada Watershed para segmentar as imagens mamográficas utilizadas, bem como as demais técnicas descritas anteriormente, adaptadas para uma melhor implementação do sistema proposto. 


\section{Capítulo 5 - Materiais e Métodos}

O presente trabalho tem por objetivo o processamento de imagens mamográficas para a detecção de nódulos em mamas densas. Tais imagens são digitalizadas e armazenadas em um banco de imagens. A segmentação destas é feita a partir da implementação de técnicas de realce de contraste e morfologia matemática, descritas a seguir.

Os mamogramas utilizados foram obtidos do Hospital das Clínicas de Ribeirão Preto FMRP-USP e da Santa Casa de Misericórdia de São Carlos.

Inicialmente, as regiões de interesse foram digitalizadas em um scanner Umax Powerlookll, com 300 e 600 pontos por polegada, com 8 bits (256 níveis de cinza) para comparação com o processamento no Matlab em uma primeira etapa de testes. Posteriormente foram utilizados os mamogramas digitalizados em um scanner a laser Lumiscan 50, com 12 bits (4096 níveis de cinza) de resolução de contraste e com uma resolução espacial de $0,15 \mathrm{~mm}$ por pixel, constituindo um banco de imagens do grupo.

As regiões de interesse foram selecionadas manualmente, sob supervisão de um radiologista, nos mamogramas originais e gravadas em arquivos separados.

Após as imagens estarem disponibilizadas na tela, o próximo passo é a detecção dos nódulos. Para tal, foi desenvolvido um software de análise e segmentação de imagens.

Para o desenvolvimento dos diversos algoritmos de processamento de imagens, foi utilizado o sistema operacional Windows e a linguagem de programação Delphi 6.0 da Borland, escolhida por fornecer um conjunto de rotinas prontas para trabalhar com imagem e por apresentar facilidades na construção da interface com o usuário. 
O Matlab foi utilizado para processar as mesmas imagens para comparar os resultados obtidos, pois disponibiliza funções que utilizam morfologia matemática para o tratamento de imagens, o que agiliza o processo de programação da função.

No próximo tópico será abordada a técnica de pré-processamento aplicada às imagens com 0 intuito de prepará-las para o processo de segmentação.

\subsection{Pré-Processamento das Imagens}

As imagens utilizadas têm uma característica particular que é a alta densidade, o que reduz o contraste, fazendo com que algumas estruturas sejam mascaradas pelos tecidos da mama. Sendo assim, foi utilizada uma técnica de pré-processamento de equalização do histograma para aumentar o contraste da imagem.

O histograma de uma imagem é simplesmente um conjunto de números indicando o percentual de pixels naquela imagem, que apresentam um determinado nível de cinza. Estes valores são normalmente representados por um gráfico de barras que fornece para cada nível de cinza o número (ou o percentual) de pixels correspondentes na imagem. Através da visualização do histograma de uma imagem obtemos uma indicação de sua qualidade quanto ao nível de contraste e quanto ao seu brilho médio (se a imagem é predominantemente clara ou escura) (Marques, 1992).

Na Figura 51 é exibida uma região de interesse antes e após a aplicação da equalização, assim como seus respectivos histogramas. 

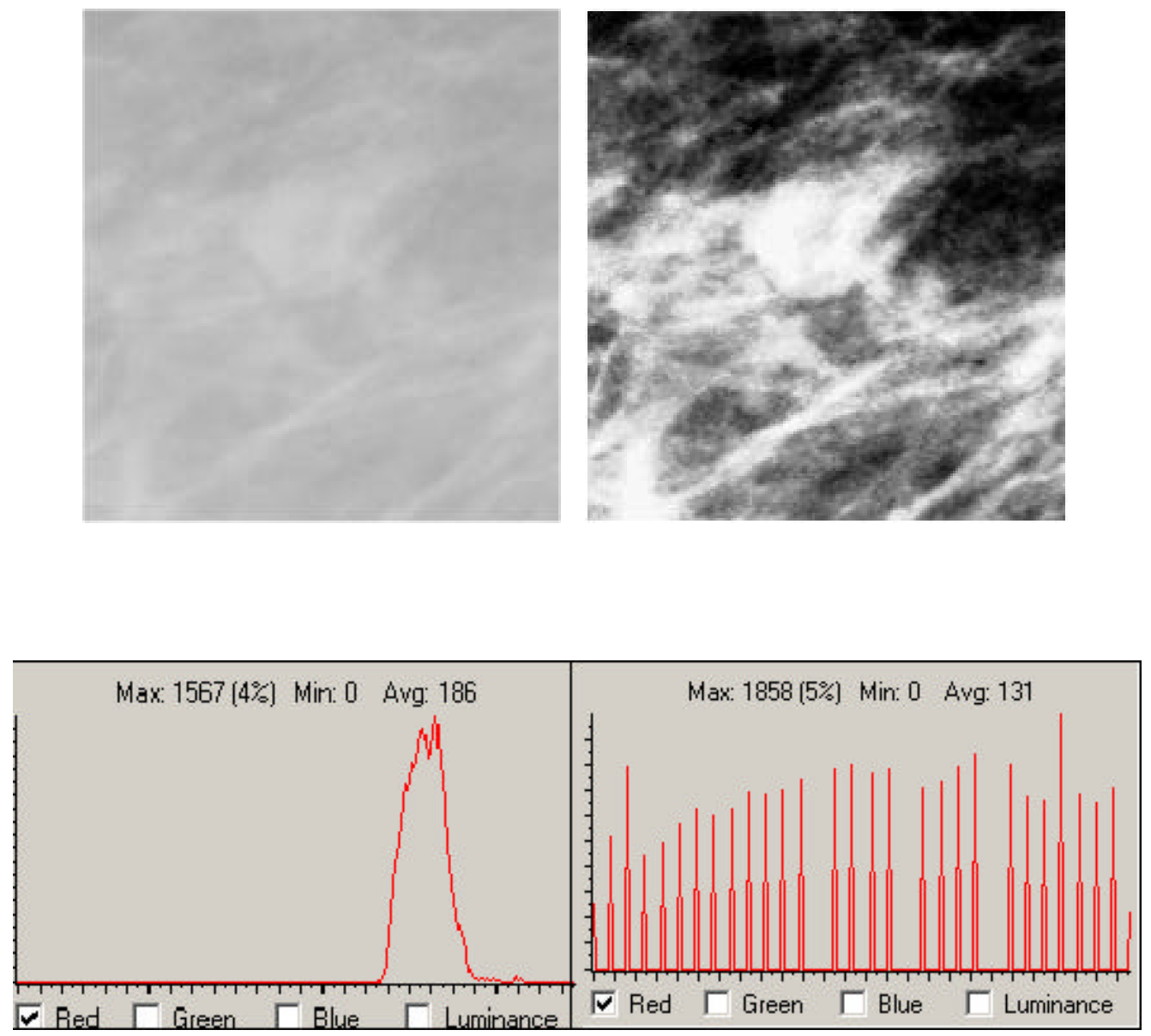

Figura 5-1 Exemplo de equalização de histograma. São mostradas as imagens original e processada e seus respectivos histogramas.

A equalização do histograma é uma técnica das mais citadas na literatura (Gauch,1992) para realce genérico de contraste. Tem a finalidade de obter um histograma uniforme, através do espalhamento da distribuição dos níveis de cinza ao longo de toda a escala de resolução de contraste. Há vários métodos empregados para a realização da equalização, sendo que a maioria deles tem bases teóricas fundamentadas na estatística. A finalidade desta técnica é expandir a distribuição dos níveis de cinza ao longo de toda a escala de contraste, aumentando, dessa maneira, a detectabilidade de aspectos da imagem. 
Cada elemento deste conjunto é calculado como:

$$
p_{r}\left(r_{k}\right)=\frac{n_{k}}{n}
$$

Onde:

$0<=\mathrm{r}_{\mathrm{k}}<=1$

$k=0,1, \ldots, L-1$, onde $L$ é o número de níveis de cinza da imagem digitalizada;

$\mathrm{n}$ = número total de pixels na imagem;

$p_{(}\left(r_{k}\right)=$ probabilidade do $k$-ésimo nível de cinza;

$\mathrm{n}_{\mathrm{k}}=$ número de pixels cujo nível de cinza corresponde a $\mathrm{k}$.

Para o cálculo, utiliza-se uma função auxiliar, denominada função de transformação. A forma mais usual de se equalizar um histograma é utilizar a função de distribuição acumulada (cdf - cumulative distribution function) da distribuição de probabilidades original, que pode ser expressa por:

$$
S_{k}=T\left(r_{k}\right)=\sum_{j=0}^{k} \frac{n_{j}}{n}=\sum_{j=0}^{k} p_{r}\left(r_{j}\right)
$$

onde:

$0 \leq r_{k} \leq 1$

$\mathrm{k}=0,1, \ldots, \mathrm{L}-1$

A inversa desta função é dada por:

$$
r_{k}=T^{-1}\left(S_{k}\right) \quad p / 0 \leq S_{k} \leq 1
$$


As imagens podem ser processadas tanto com a aplicação da técnica de equalização do histograma quanto em seu formato original. Para isto foi desenvolvido um software baseado no algoritmo abordado a seguir.

\subsection{O Algoritmo}

A transformada Watershedpode ter vários tipos de implementações, de acordo com o tipo de imagem a ser processada e o tipo de marcador utilizado.

O método analisa os níveis de cinza do histograma da imagem, já que é baseado no princípio de que as estruturas de interesse correspondem a uma mesma freqüência destes níveis, sendo que gradiente e bordas correspondem a altas freqüências (Beucher, 1979). Na transformada Watershed original, a gota "cai" até o ponto de mínimo, enchendo a bacia. Beucher e Meyer propuseram a inversão da transformada, onde o ponto de mínimo seria um furo por onde a água inundaria a bacia (Beucher, 1990).

A técnica inicialmente implementada segue as seguintes etapas:

$\Rightarrow$ Imagem Original é mostrada no monitor (Figura 5-2).

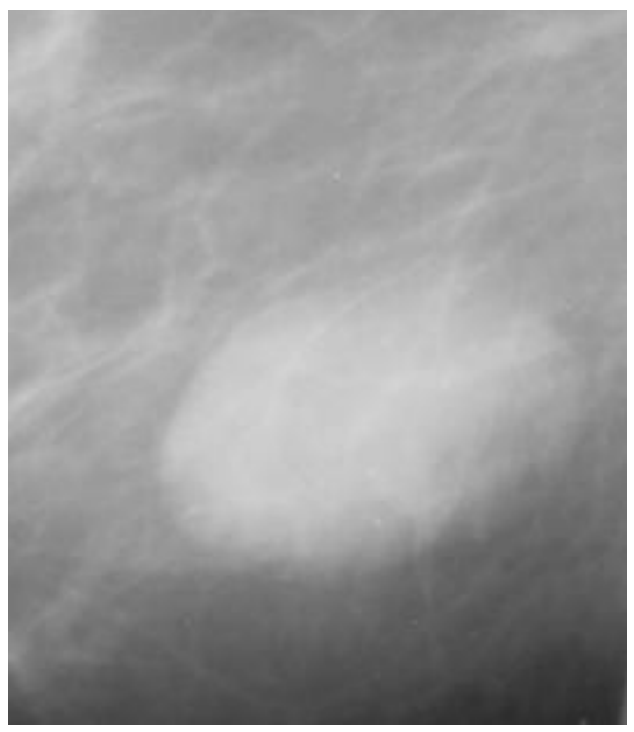

Figura 5-2 Exemplo de imagem original. 
$\Rightarrow$ Cálculo do gradiente interno (objeto) e externo (fundo) para toda a imagem;

$\Rightarrow$ Cálculo e armazenamento dos pixels mais brilhantes, (pontos de mínimo), que serão os marcadores da imagem (Figura 5-3).

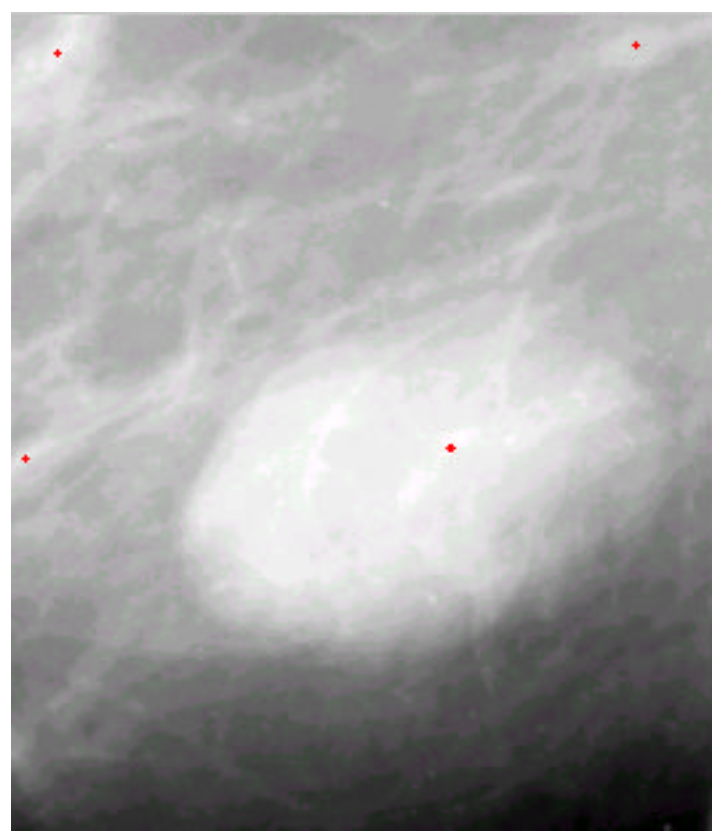

Figura 5-3 Imagem original e marcadores da imagem.

$\Rightarrow$ Inversão do gradiente e cálculo de distâncias (Hit-and-Miss: elimina o objeto para trabalhar com o fundo; Seqüência de tining no fundo; SKIZ: tickening no $1^{\circ}$ plano), para montar o esqueleto através da análise da vizinhança, para eliminar pontos, gerando as zonas de influência. Utilizando o valor absoluto do gradiente, constróise uma espécie de "topografia" (Figura 5-4); 


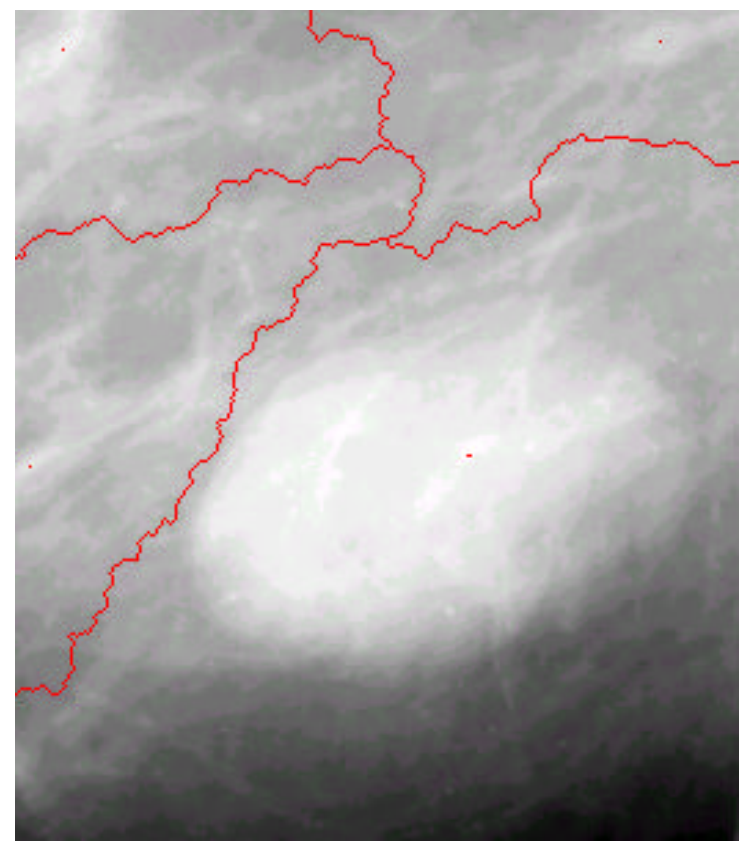

Figura 5-4 Imagem original, marcadores e zonas de influência.

$\Rightarrow$ Regiões homogêneas compõem as regiões planas da "topografia";

$\Rightarrow$ "Inundação das regiões baixas", a partir dos pontos de mínimo agindo como pontos sementes para o crescimento de regiões, onde a parada é o gradiente da imagem;

$\Rightarrow$ As áreas marcadas com diferentes "níveis de água" formam os segmentos separados pelas linhas da transformada Watershed (Figura 55). 

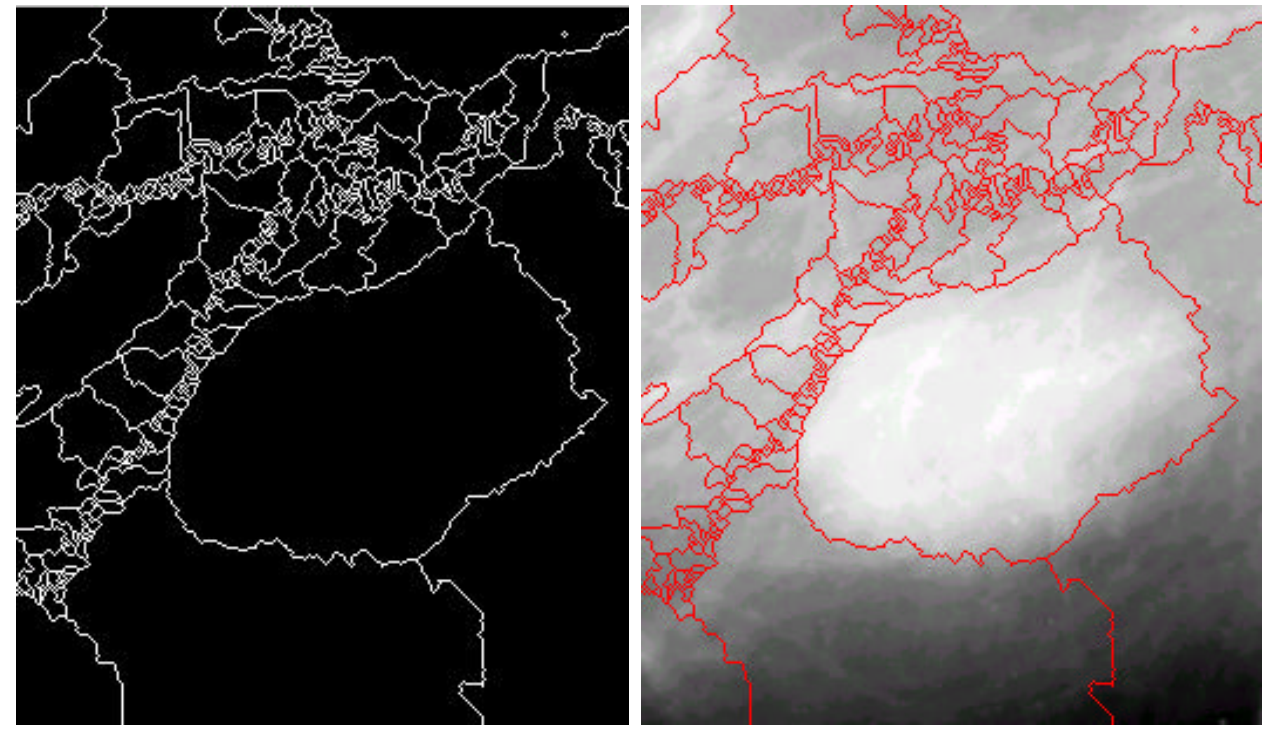

Figura 5-5 Imagem com as linhas de Watershed e junção com a imagem original.

$\Rightarrow$ A imagem é então binarizada e o nódulo destacado do restante da imagem, Figura 5-6.
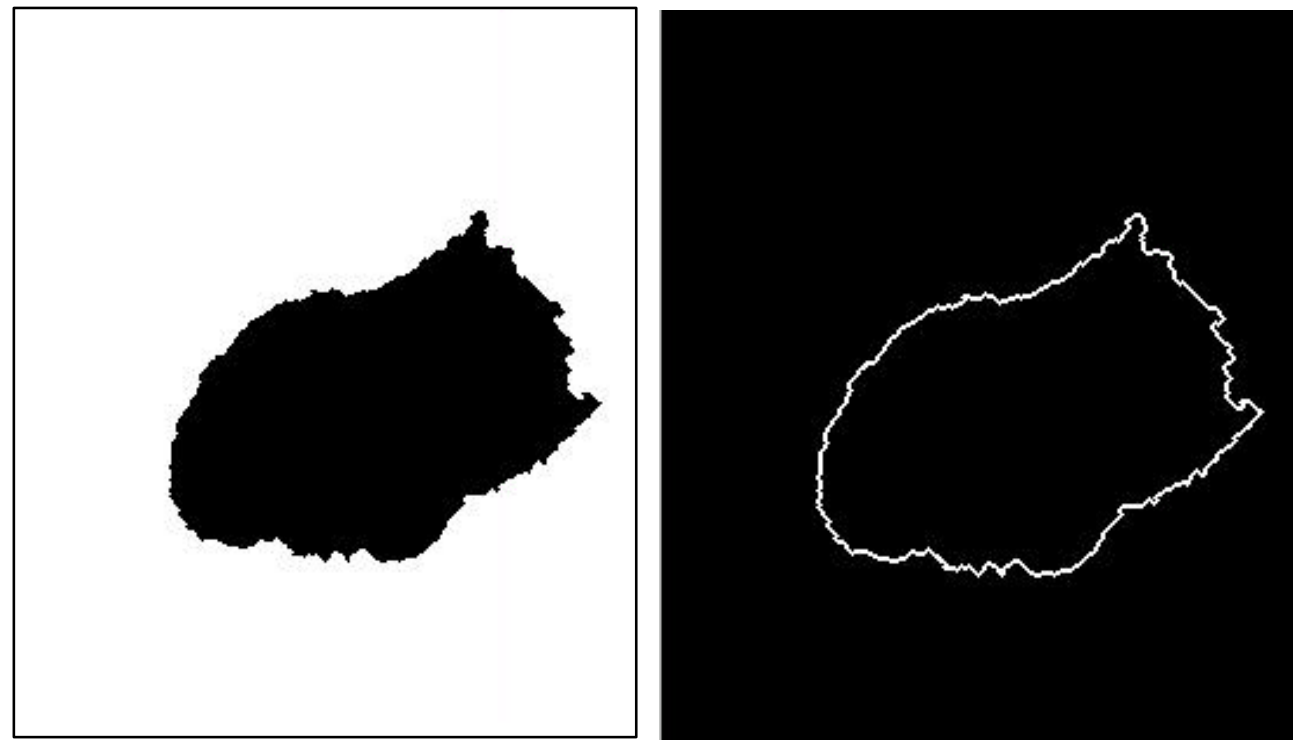

Figura 5-6 Imagem segmentada e o seu contorno. 
$\Rightarrow$ Resultado final, Figura 5-7.

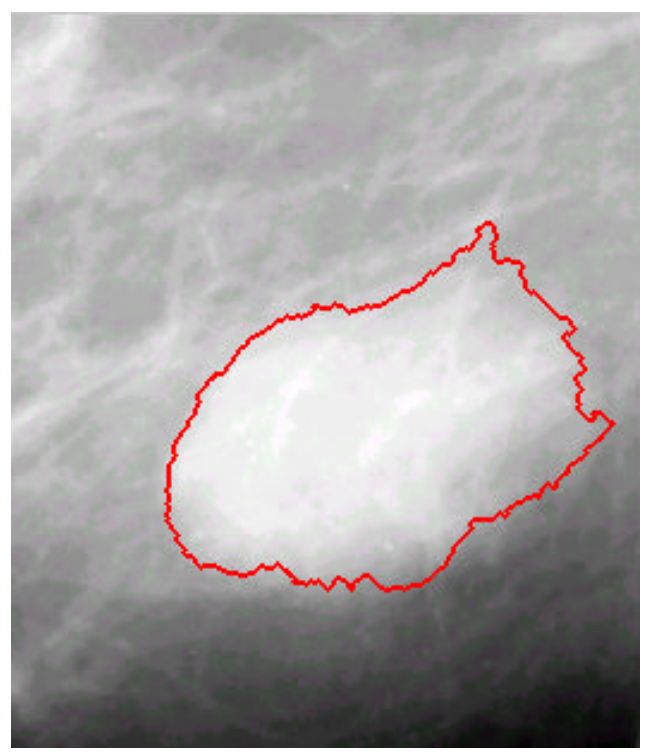

Figura 5-7 Imagem original e contorno sobre a imagem.

\subsection{Pós-Processamento: Corrigindo Defeitos da Segmentação}

Muitas vezes, o resultado da segmentação não é adequado. Para corrigir os defeitos residuais, na etapa denominada de pós-processamento, utilizam-se algumas técnicas apresentadas a seguir.

\subsubsection{Rotulação}

Em imagens binárias, um pixel será preservado, eliminado ou invertido em função de ter um certo número de vizinhos iguais ou diferentes (Parker,1994). Rotular uma imagem binária significa atribuir uma única cor para pixels pertencentes a uma mesma região conectada, como mostrado na Figura 5-8. 

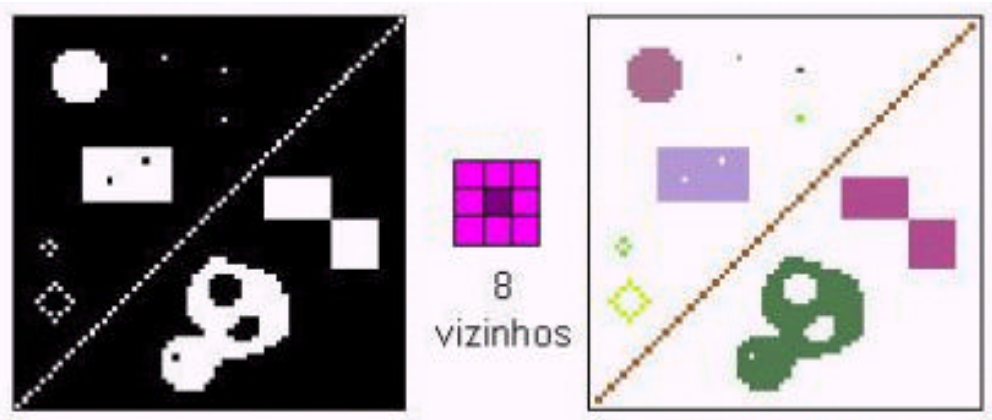

10 objetos

Figura 5-8 - Operação de rotulação (labeling) Imagem original e Conectividade 8

As imagens digitais têm algumas propriedades que precisam ser citadas. Uma imagem digital é uma imagem $f(x, y)$ discretizada tanto espacialmente quanto em amplitude. Portanto, pode ser vista como uma matriz cujas linhas e colunas identificam um ponto na imagem, cujo valor corresponde ao nível de cinza naquele ponto. Quando nos referirmos a um pixel em particular, utilizaremos letras minúsculas, tais como $p$ e $q$. Um subconjunto de pixels de $f(x, y)$ será indicado por $S$ (Marques, 1992).

A vizinhança de um pixel $p$, de coordenadas $(x, y)$, tem 4 vizinhos horizontais e verticais, cujas coordenadas são $(x+1, y), \quad(x-1, y), \quad(x, y+1) e$ $(\mathrm{x}, \mathrm{y}-1)$. Estes pixels formam a chamada "4-vizinhança" de $p$, que será designada $\mathrm{N} 4(p)$. Os quatro vizinhos diagonais de $p$ são os pixels de coordenadas $(x-1, y-1),(x-1, y+1),(x+1, y-1)$ e $(x+1, y+1)$, que constituem 0 conjunto $\mathrm{Nd}(p)$.

A "8-vizinhança"de $p$ é definida como: $\mathrm{N} 8(p)=\mathrm{N} 4(p) \cup \mathrm{Nd}(p)$

Os vários tipos de vizinhança estão ilustrados na Figura 5-9.
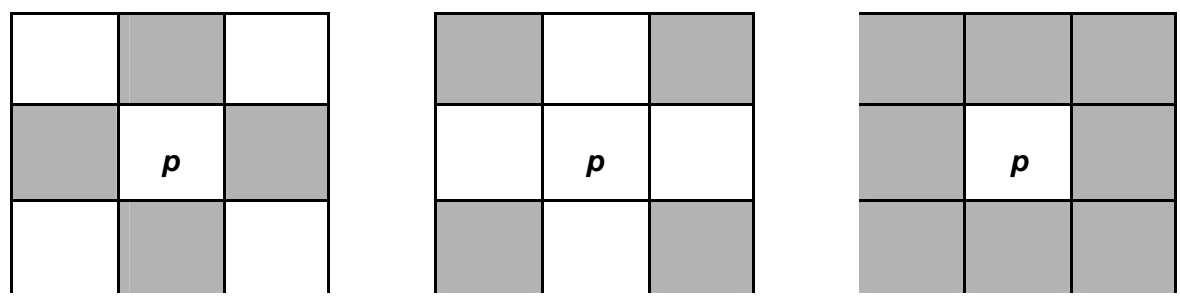

Figura5-9 - Conceitos de 4-vizinhança, vizinhança diagonal e 8-vizinhança 
A conectividade entre pixels é um importante conceito usado para estabelecer limites de objetos e componentes de regiões em uma imagem. Para se estabelecer se dois pixels estão conectados, é necessário determinar se eles são adjacentes segundo algum critério e se seus níveis de cinza satisfazem a um determinado critério de similaridade.

O algoritmo implementado no pós-processamento segue a teoria de que uma imagem é percorrida pixel por pixel, da esquerda para a direita e de cima para baixo, sendo $p$ o pixel em qualquer passo no processo de varredura e sejam $r$ e $t$, respectivamente, os vizinhos superior e esquerdo de $p$. A natureza da seqüência de varredura garante que, quando chegarmos a $p$, os pontosre $t$ já tenham sido encontrados e rotulados se tiverem valor 1 (Gonzalez, 1992).

Se o valor de $p$ é 0 , desloca-se para a próxima posição. Se o valor de $p$ é 1, examina-se re $t$. Se ambos forem 0 , atribui-se a $p$ um novo rótulo (com base na informação corrente, esta é a primeira vez que o componente conexo foi encontrado). Se apenas um dos dois vizinhos for 1 , atribui-se a $p$ o seu rótulo. Se ambos forem 1 e possuem o mesmo rótulo, atribuise a $p$ aquele rótulo. Se ambos forem 1 , mas possuem rótulos diferentes, atribui-se um dos rótulos a $p$ e anota-se que os dois rótulos são equivalentes (isto é, os pontos $r$ e $t$ estão conectados por $p$ ). Ao fim da varredura, todos os pontos com valor 1 terão sido rotulados, mas alguns destes rótulos poderão ser equivalentes. Agora só nos resta ordenar todos os pares de rótulos equivalentes em classes de equivalência, atribuir um rótulo diferente a cada classe e, então, percorrer a imagem novamente, trocando-se cada rótulo pelo atribuído a sua classe de equivalência.

A rotulação de componentes conectados-de-8 se faz da mesma maneira, mas os dois vizinhos diagonais superiores de $p$, denotados por $q$ e $s$, devem também ser examinados. A natureza da seqüência em que a imagem é percorrida garante que esses vizinhos já terão sido processados quando o procedimento tiver alcançado $p$. Se $p$ for 0 , muda-se para a próxima posição. Se $p$ for 1 e todos os seus quatro vizinhos forem 0 , atribui-se a $p$ um novo rótulo. Se apenas um dos vizinhos for 1 , atribuirse a $p$ o seu rótulo. Se dois ou 
mais vizinhos forem 1, atribui-se um dos rótulos a $p$ e anota-se as equivalências apropriadas. Após terminar de percorrer a imagem, ordena-se os pares de rótulos equivalentes em classes de equivalência, atribui-se um rótulo único a cada classe e percorre-se a imagem uma segunda vez, trocando-se cada rótulo pelo atribuído a sua classe de equivalência. A rotulação implementada analisa os vizinhos conectados-de-8.

Após a rotulação, os pixels que chamamos de ruídos na imagem são eliminados ao calcular a média e excluir os rótulos que estiverem abaixo desta.

Após a rotulação, a imagem resultante é alinhada à imagem original em níveis de cinza, com o intuito de comparar as duas imagens, destacar o nódulo e chamar a atenção do radiologista para uma área de interesse.

A seguir é apresentado o diagrama de blocos do sistema desenvolvido (Figura 5-10):

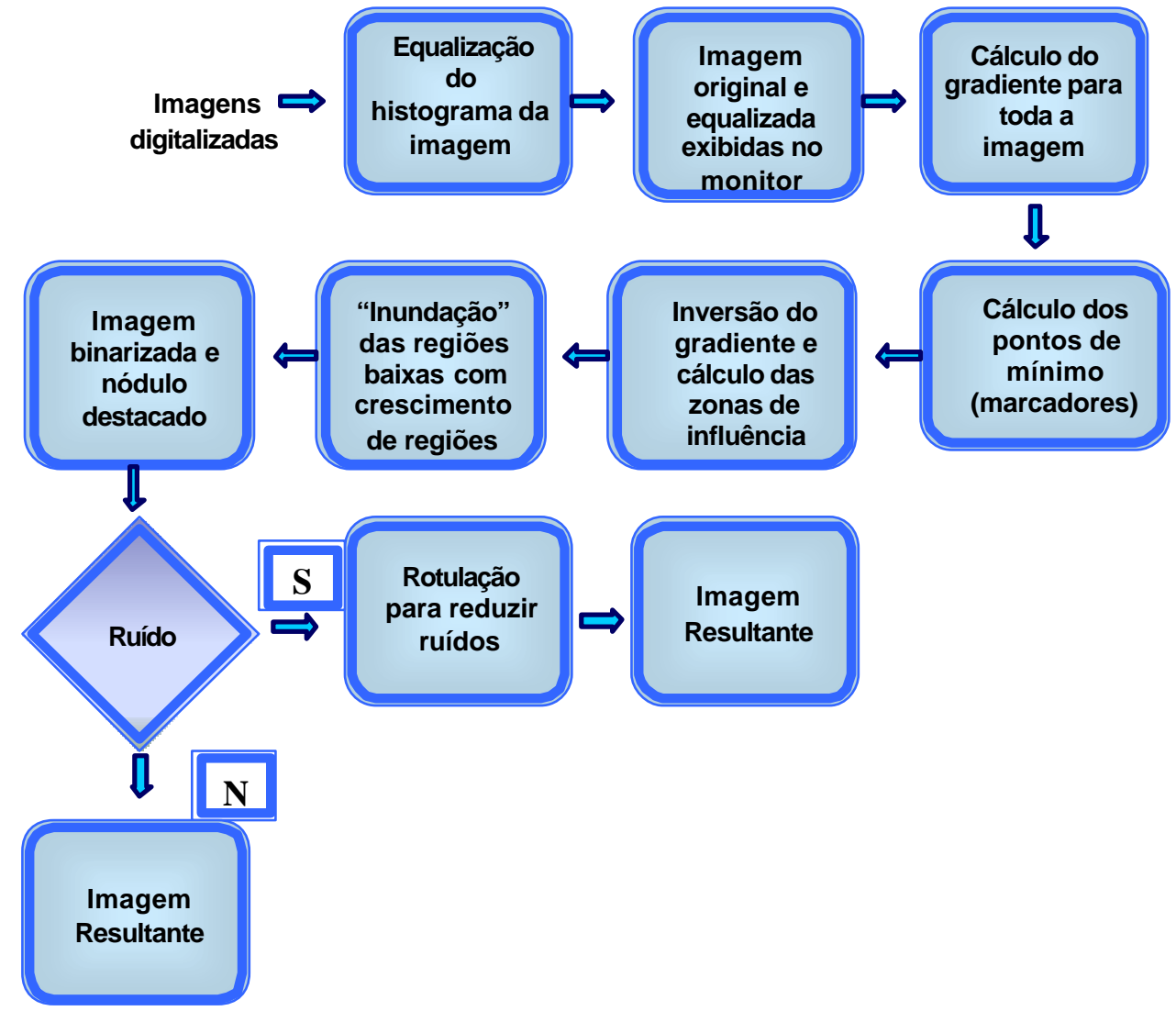

Figura 5-10 - Diagrama de Blocos representando o Sistema Desenvolvido 


\subsection{Problemas Encontrados}

É possivel que a transformada Watershed de imagens complexas ou com ruído produza uma imagem muito carregada de detalhes indesejáveis. Este problema é denominado supersegmentação e ocorre devido ao grande número de mínimos locais na imagem. Nesse caso, a transformada Watershed acaba por segmentar a imagem em lugares não desejados.

Este problema pode ser resolvido com a obtenção de marcadores na imagem que indicam onde o método deve segmentar e onde deve ignorar.

A definição e a escolha de um marcador ótimo para o processamento das imagens podem ser obtidas de muitas formas. Deve-se levar em conta as características da imagem com que se está trabalhando, como contraste e ruído, por exemplo. A extração de marcadores é o passo mais difícil nestetipo de segmentação.

Outro problema encontrado foi com relação à característica de densidade das imagens adquiridas: alguns dos laudos dos radiologistas davam informação apenas como "mamas densas" sem destacar identificação da existência de qualquer tipo de lesão. No início, como a validação era feita apenas baseada neste primeiro laudo, o resultado de um achado após o processamento era classificado como falso-positivo. Todavia, após um estudo dos laudos de alguns exames complementares como o ultra-som, por exemplo, pudemo-nos certificar da correta detecção do sistema desenvolvido, re-classificando o resultado, então, como um verdadeiro-positivo. 


\section{Resultados}

Na Figura 6-1 é apresentada a tela do software desenvolvido. O primeiro passo para o processamento é abrir a imagem que pode ser nos formatos TIFF ou BMP. Aplica-se então a transformada Watershed nesta imagem. Equaliza-se o histograma da imagem original e aplica-se a transformada na imagem equalizada. A rotulação é aplicada nas duas imagens binárias através do menu "Média".

O principal parâmetro do sistema é a escolha do valor de threshold do marcador da imagem que neste caso é de 3160 níveis de cinza para uma faixa entre 0 e 4095 níveis.

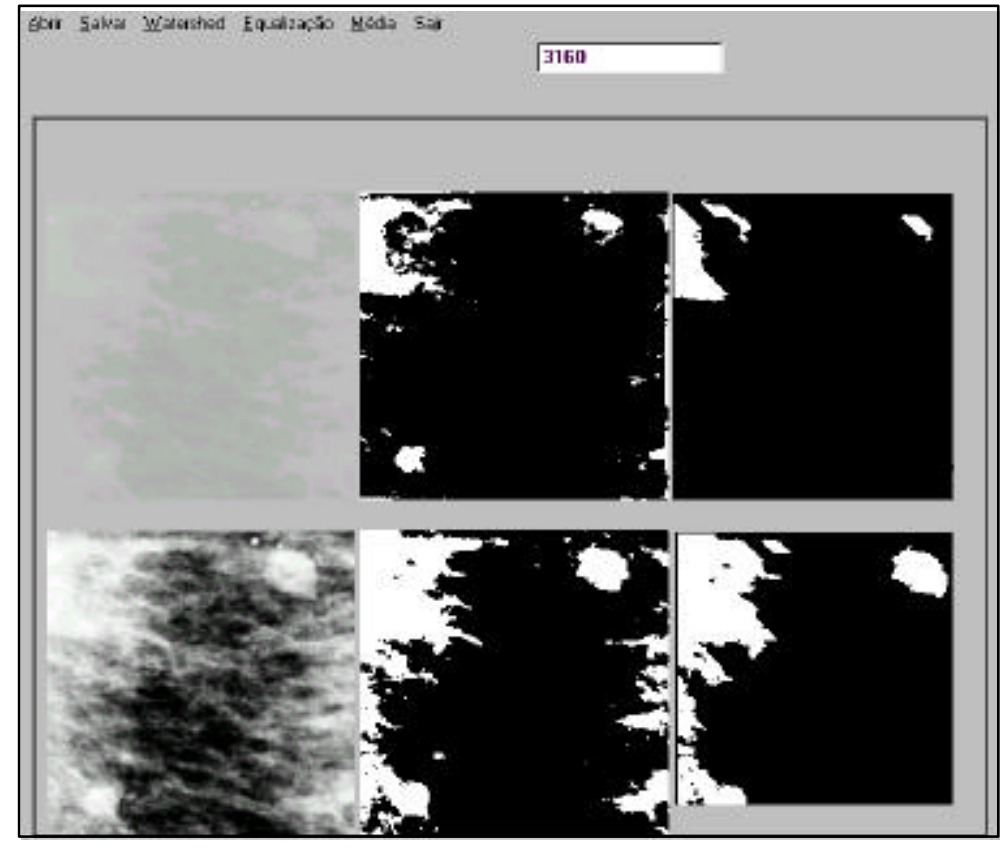

Figura 6-1 - Diagrama de Blocos representando o Sistema Desenvolvido. 
Foram processadas regiões de interesse de 319 mamogramas, sendo 165 normais e 154 com presença de nódulos, de acordo com o laudo do radiologista e do ultra-som como exame complementar. Os resultados obtidos estão resumidos na Tabela 6-1, 6-2, 6-3, onde temos FN (Falso-Negativo), VP (Verdadeiro-Positivo), FP (Falso-Positivo) e VN (Verdadeiro-Negativo).

Tabela 6-1 - Resultados obtidos com o processamento das imagens

\begin{tabular}{|l|c|c|c|c|c|c|c|c|}
\hline \multicolumn{1}{|r|}{ Imagem } & FN & $\%$ & VP & $\%$ & FP & $\%$ & VN & $\%$ \\
\hline Original & 122 & 79,22 & 32 & 20,78 & 6 & 3,60 & 159 & 96,40 \\
Equalizada & 10 & 6,66 & 144 & 93,34 & 17 & 10,30 & 148 & 89,70 \\
\hline
\end{tabular}

Tabela 6-2 - Resultados VP e taxa de ruído

\begin{tabular}{|l|c|c|l|l|}
\hline \multicolumn{1}{|c|}{ Resultados } & VP & $\%$ & Ruído & $\%$ \\
\hline Original & 32 & 20,78 & 11 & 33,34 \\
\hline Equalizada & 144 & 93,34 & 41 & 28,47 \\
\hline
\end{tabular}

Segundo as taxas apresentadas nas tabelas acima, foram obtidos aproximadamente $93 \%$ de detecção de nódulos nas imagens onde foi aplicada a técnica de pré-processamento. Aproximadamente $28 \%$ destas imagens apresentaram ruídos após a segmentação. Já os mamogramas processados sem o pré-processamento, somente com a transformada Watershed, apresentaram apenas $21 \%$ de detecção de nódulos, com $79 \%$ de falsonegativo, taxa esta muito alta de erro. Na Tabela 6-3 são apresentados os índices de erro e acerto gerais. 
Tabela 6-3 - Taxas de acertos e erros obtidos com o processamento das imagens.

\begin{tabular}{|l|l|l|l|l|l|}
\hline Imagens & № Acertos & $\%$ & № Erros & $\%$ & Total \\
\hline Original & 191 & 59,87 & 128 & 40,13 & 319 \\
\hline Equalizada & 292 & 91,50 & 27 & 8,50 & 319 \\
\hline
\end{tabular}

Pelas taxas acima apresentadas podemos analisar o número total de acertos, incluindo as taxas de detecção ou verdadeiro-positivo e verdadeironegativo, que nas imagens originais processadas somente com a transformada foi de aproximadamente $60 \%$ e nas imagens onde foi aplicado $o$ pré-processamento $92 \%$. O número total de erro, incluindo Falso-Positivo e Falso-Negativo nas imagens originais processadas somente com a transformada foi de $40,13 \%$, já nas imagens onde as técnicas foram combinadas foi de $8,50 \%$.

Os resultados dos mamogramas processados utilizando a combinação da técnica de equalização do histograma como pré-processamento e a transformada Watershed para segmentação demonstraram que são melhores do que se utilizarmos apenas a segunda técnica na detecção dos nódulos.

Das imagens onde houve a detecção dos nódulos, aproximadamente $28 \%$ apresentaram ruído após o processamento. Aplicando a rotulação e eliminação de pixels, o pós-processamento reduziu em até $86 \%$ estes ruídos, destacando mais os nódulos detectados.

A seguir são apresentadas algumas imagens de regiões de interesse processadas (Figura 6-2 à Figura 6-10), tanto exemplos de imagens onde os nódulos foram detectados corretamente, como exemplos de imagens com detecção correta e ruídos e imagens onde não houve a detecção. 


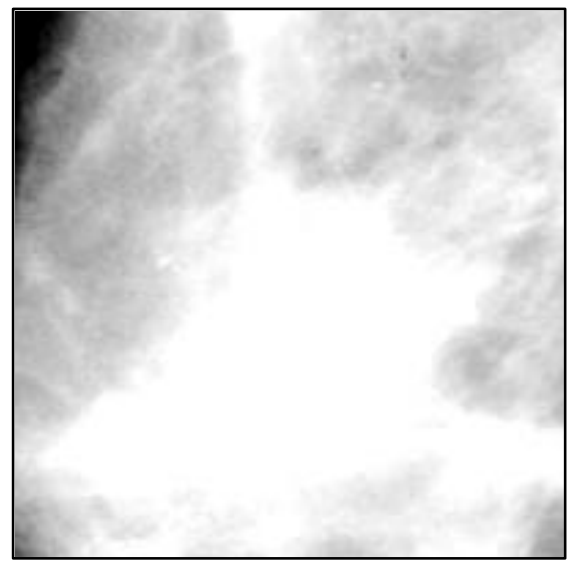

(a)

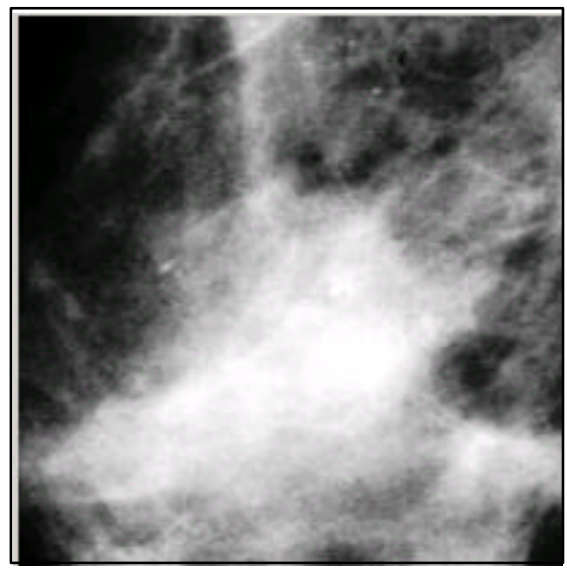

(c)

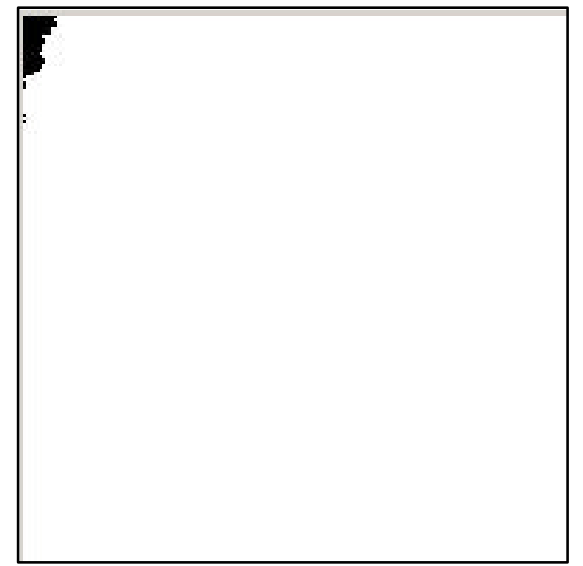

(b)

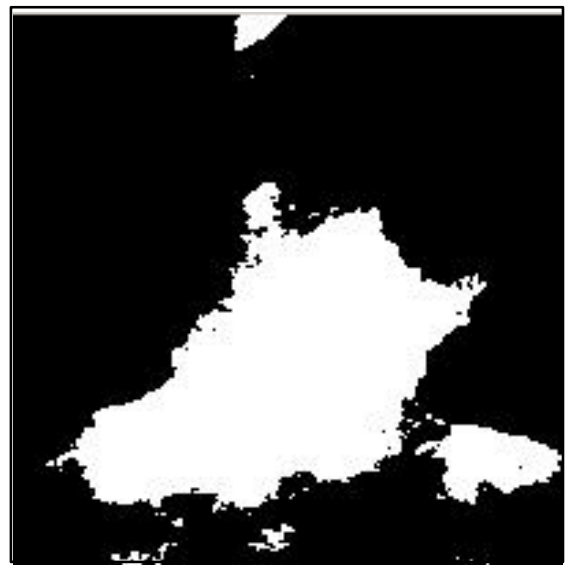

(d)

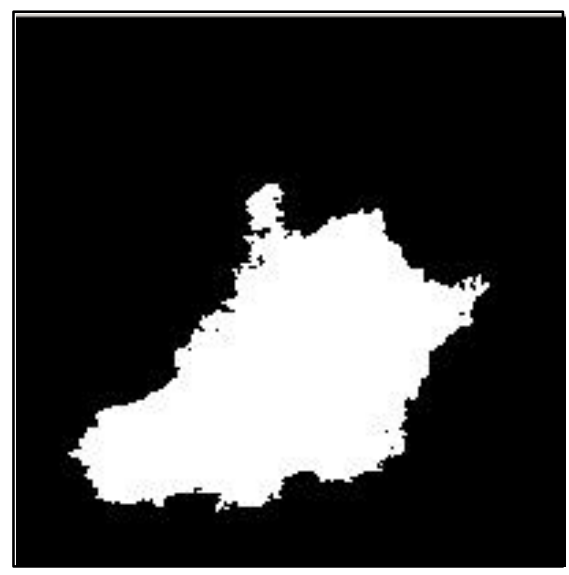

(e)

Figura 6-2 (a) Imagem Original; (b) Imagem Segmentada somente com Watershed; (c) Imagem Equalizada; (d) Imagem Segmentada com a combinação de ambas as técnicas e apresentação de ruídos; (e) Imagem final após rotulação. 


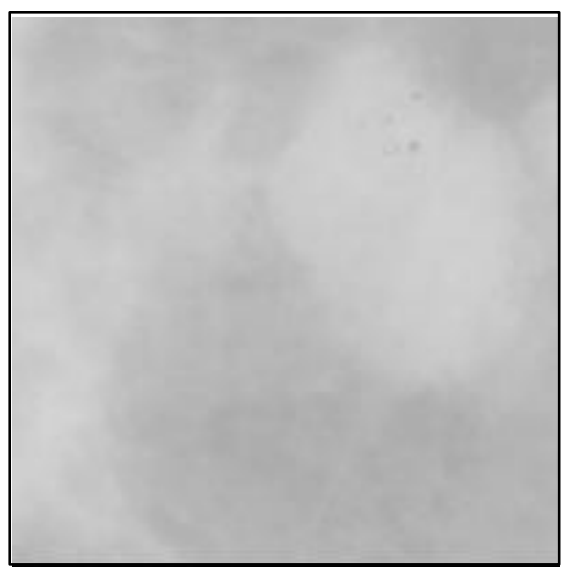

(a)

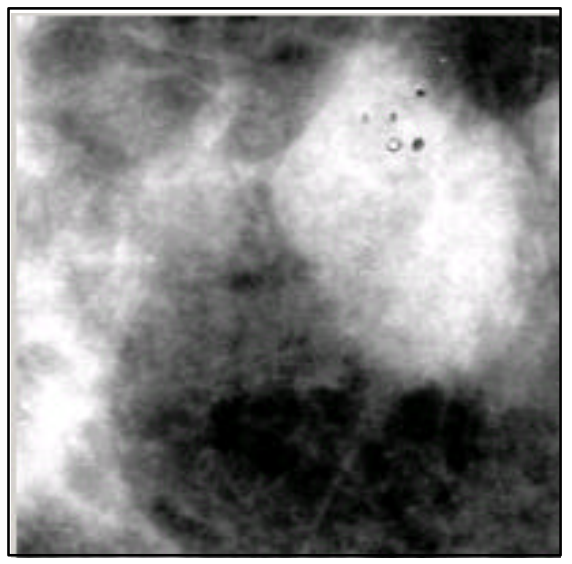

(c)

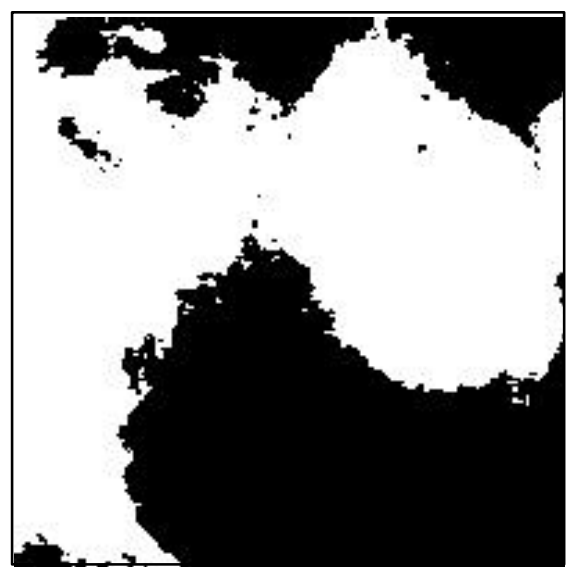

(b)

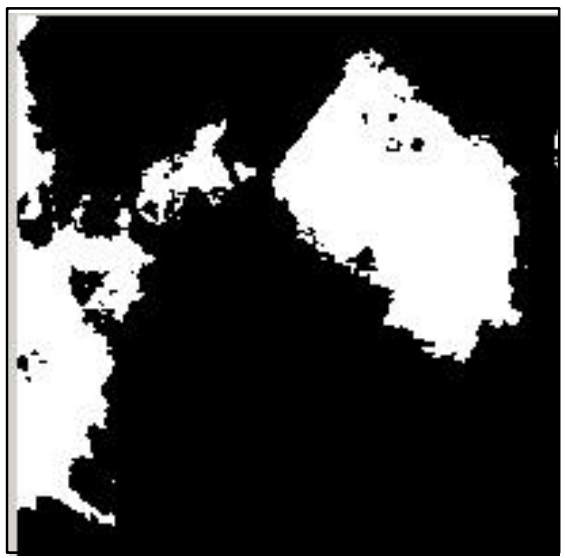

(d)

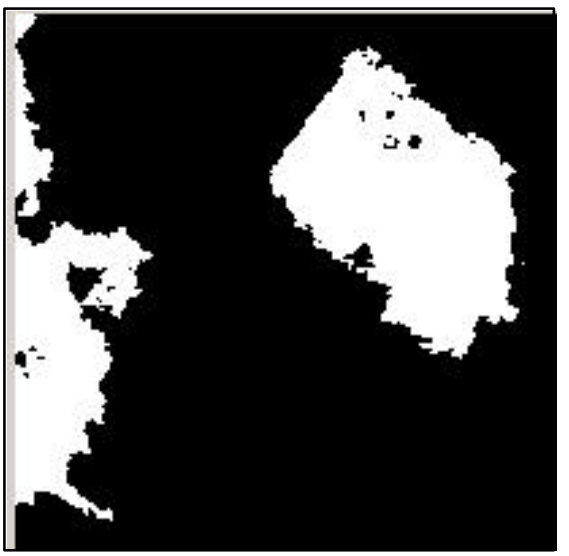

(e)

Figura 6-3 (a) Imagem Original; (b) Imagem Segmentada somente com Watershed; (c) Imagem Equalizada; (d) Imagem Segmentada com a combinação de ambas as técnicas e apresentação de ruídos; (e) Imagem final após rotulação. 


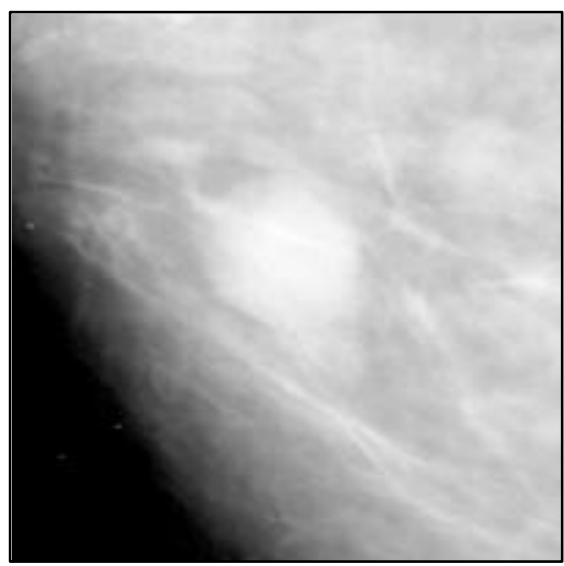

(a)

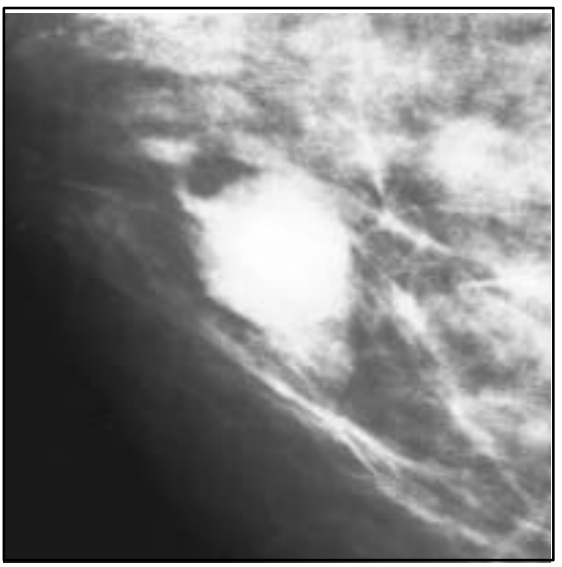

(c)

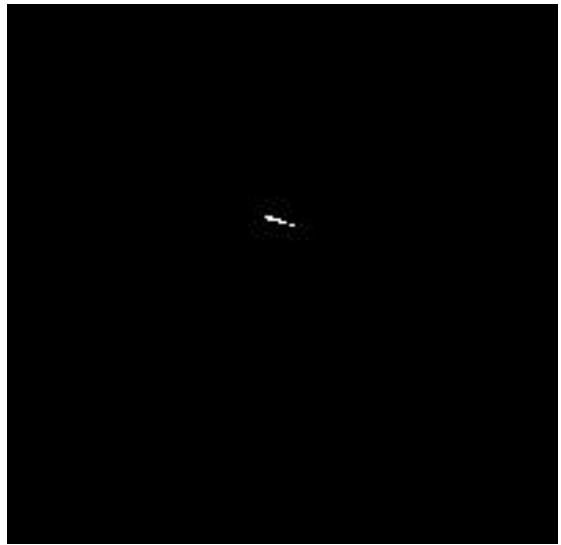

(b)

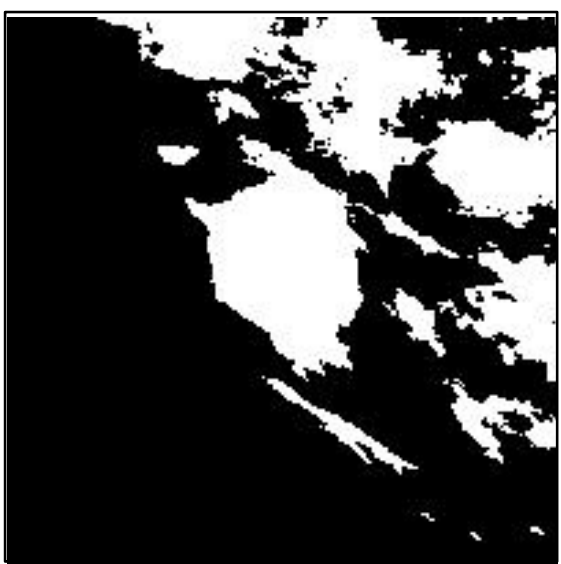

(d)

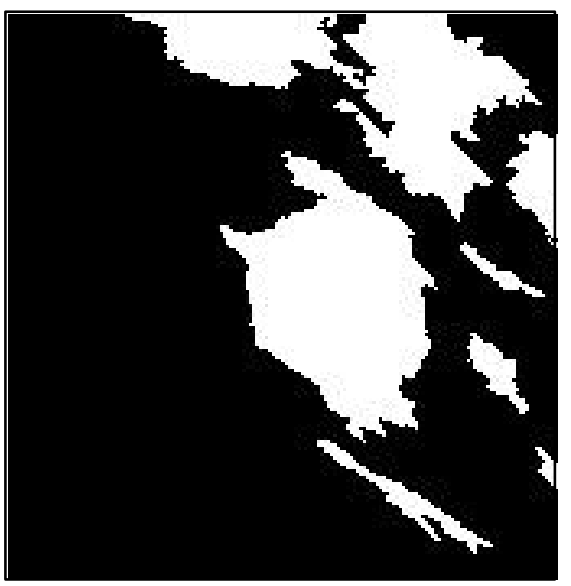

(e)

Figura 6-4 (a) Imagem Original; (b) Imagem Segmentada somente com Watershed; (c) Imagem Equalizada; (d) Imagem Segmentada com a combinação de ambas as técnicas e apresentação de ruídos; (e) Imagem final após rotulação. 


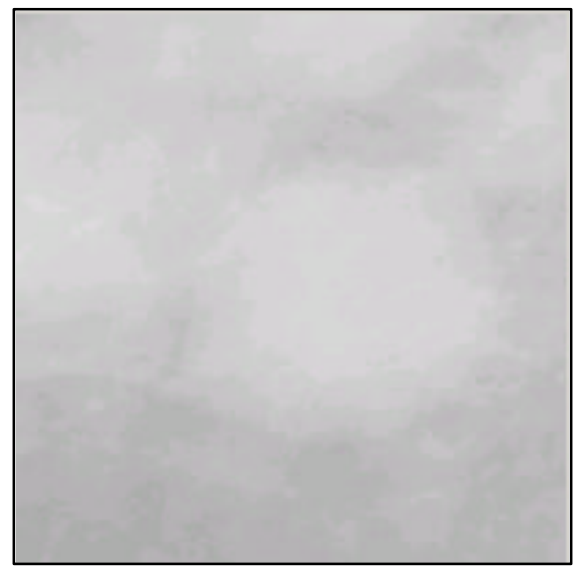

(a)

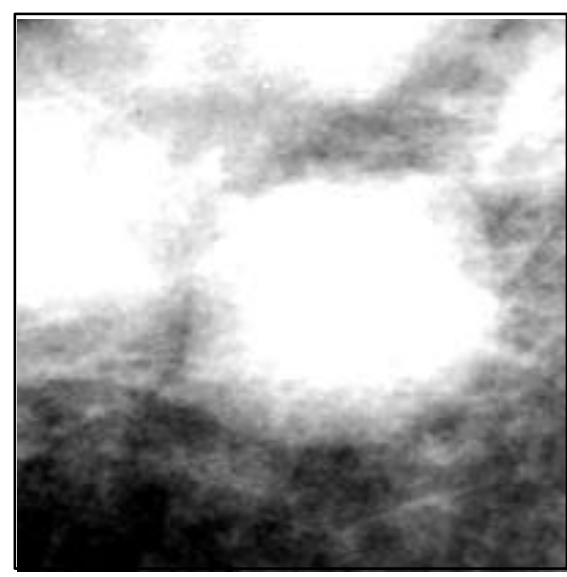

(c)

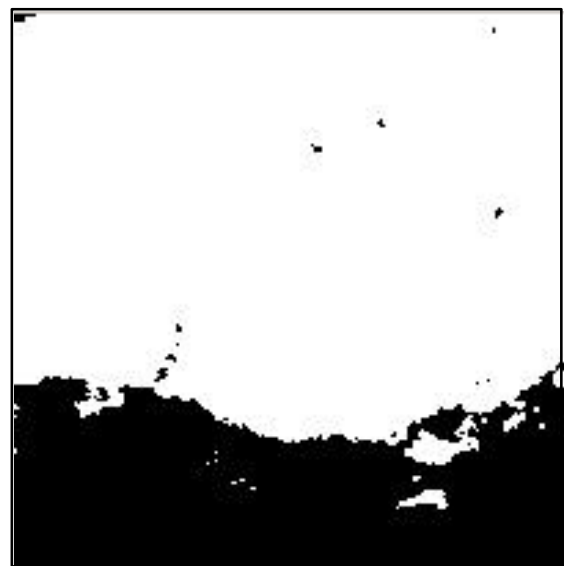

(b)

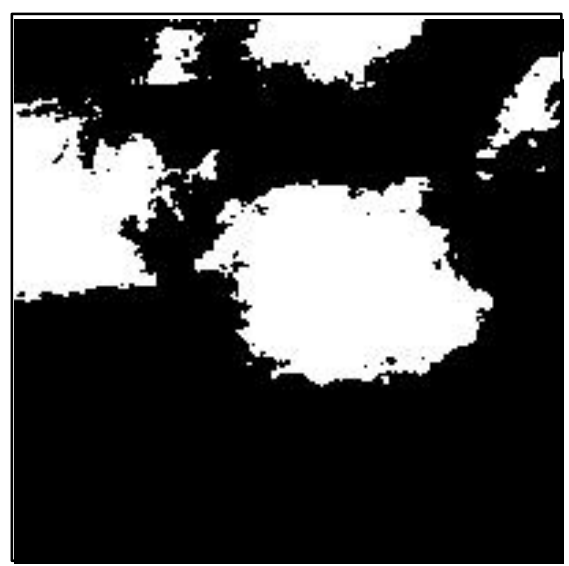

(d)

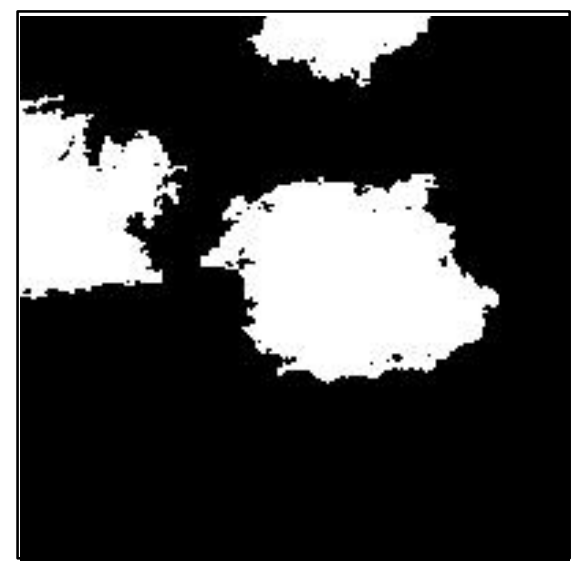

(e)

Figura 6-5 (a) Imagem Original; (b) Imagem Segmentada somente com Watershed; (c) Imagem Equalizada; (d) Imagem Segmentada com a combinação de ambas as técnicas e apresentação de ruídos; (e) Imagem final após rotulação. 


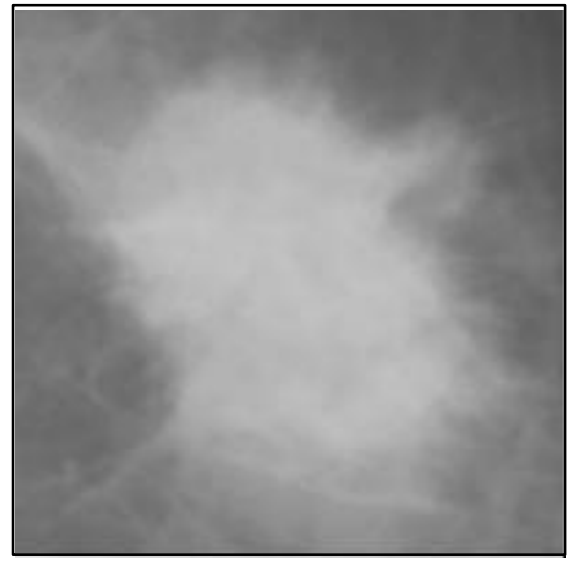

(a)

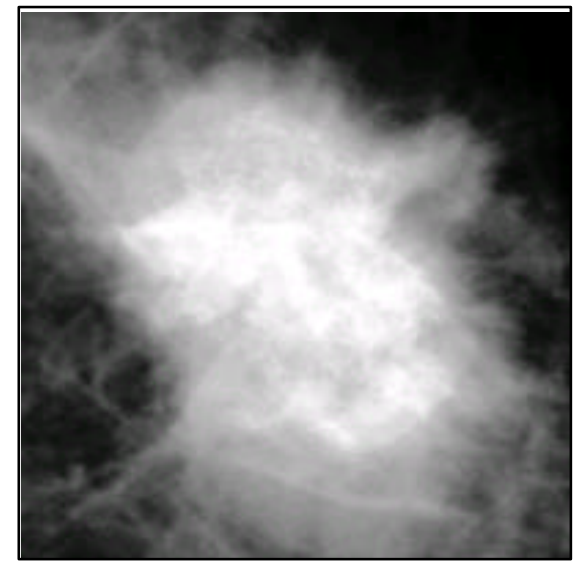

(c)

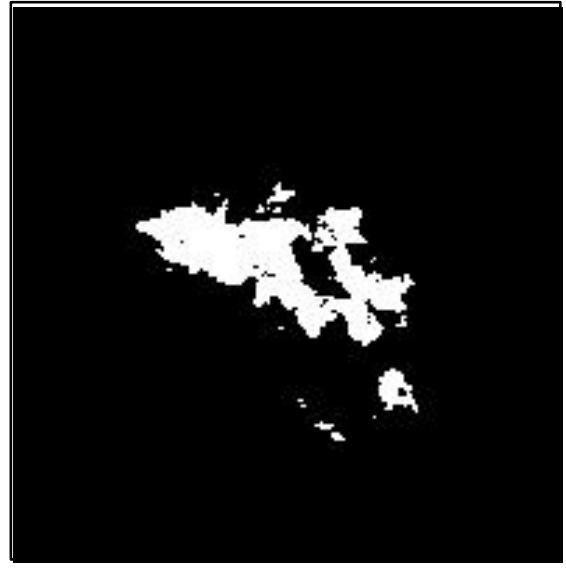

(b)

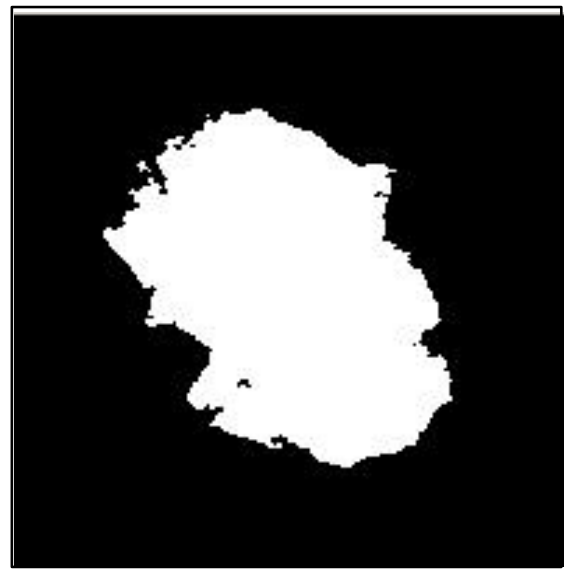

(d)

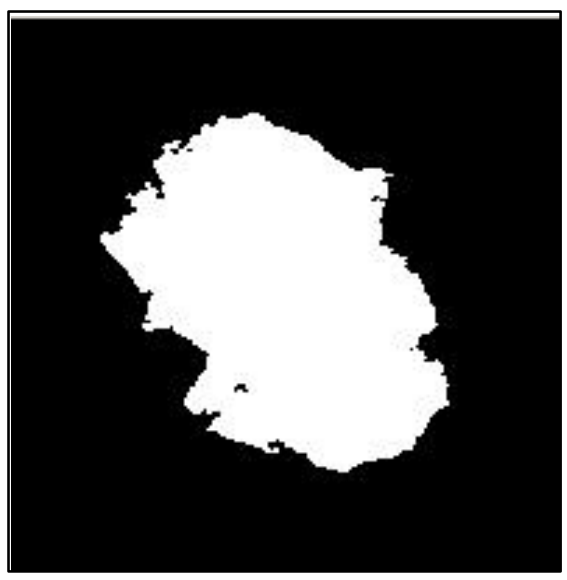

(e)

Figura 6-6 (a) Imagem Original; (b) Imagem Segmentada somente com Watershed; (c) Imagem Equalizada; (d) Imagem Segmentada com a combinação de ambas as técnicas e apresentação de ruídos; (e) Imagem final após rotulação. 


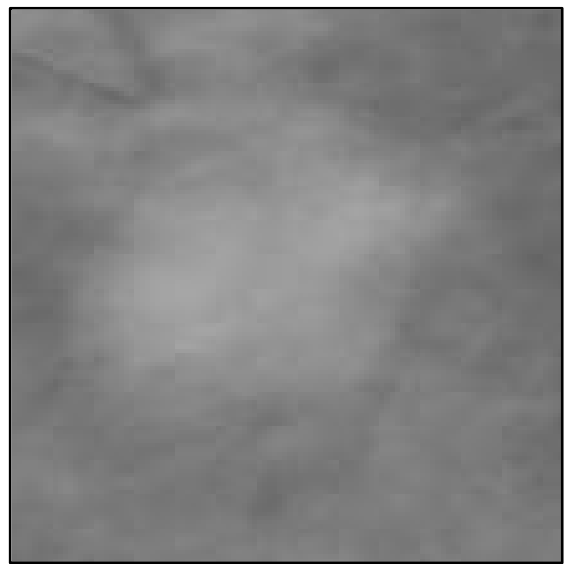

(a)

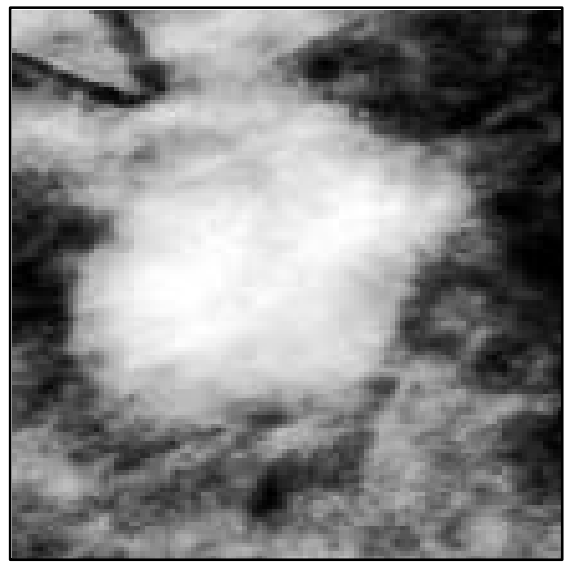

(c)

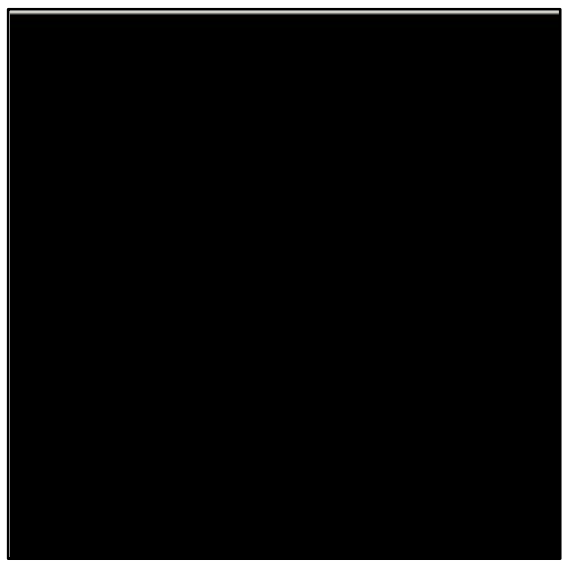

(b)

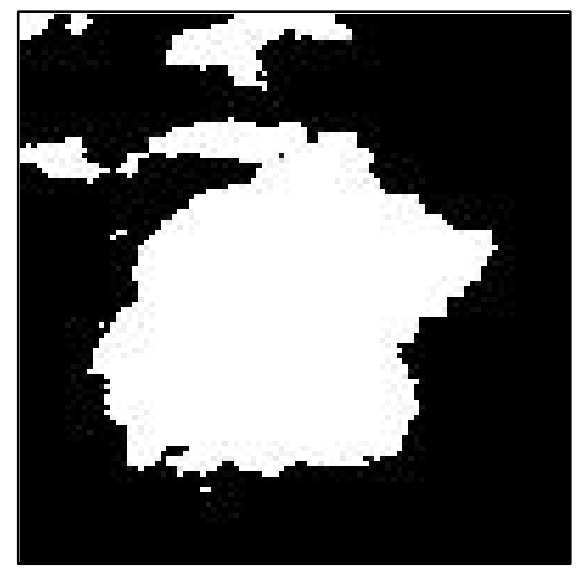

(d)

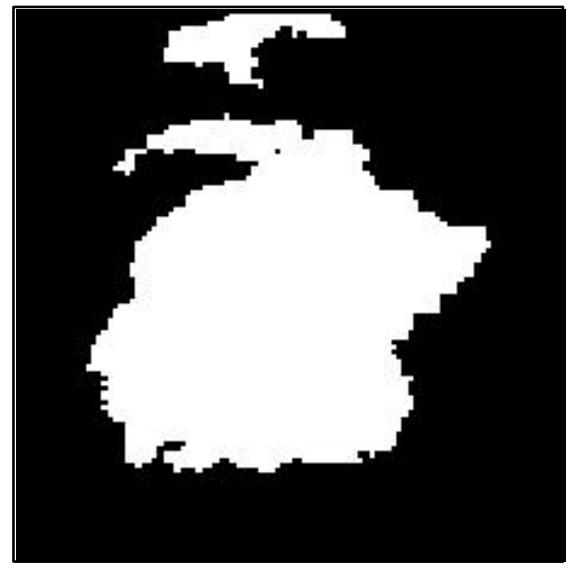

(e)

Figura 6-7 (a) Imagem Original; (b) Imagem Segmentada somente com Watershed, indicando um falso-negativo; (c) Imagem Equalizada; (d) Imagem Segmentada com a combinação de ambas as técnicas e apresentação de ruídos; (e) Imagem final após rotulação. 


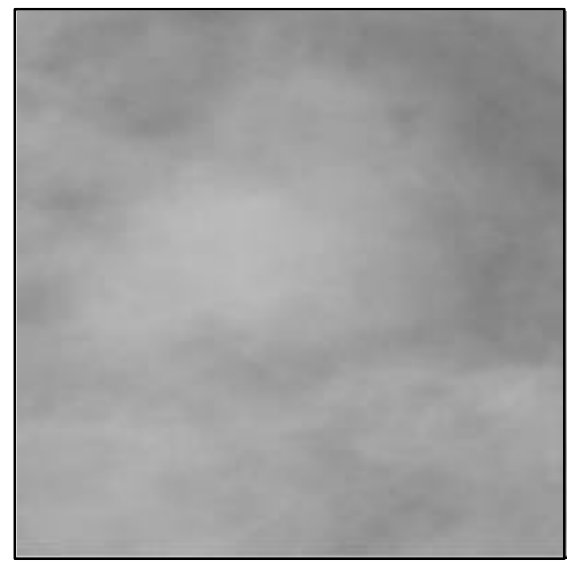

(a)

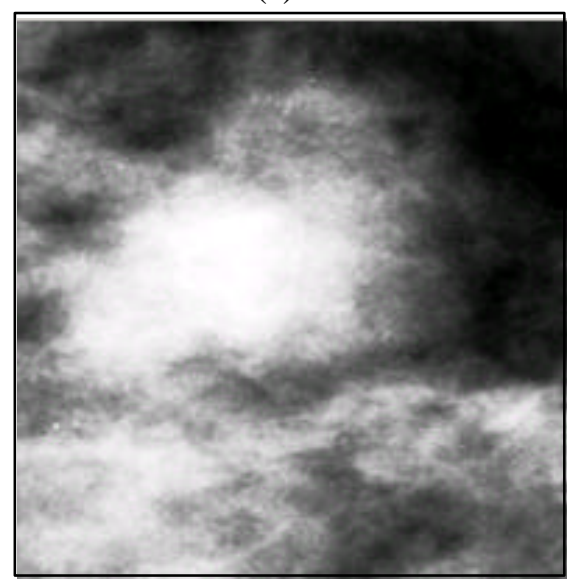

(c)

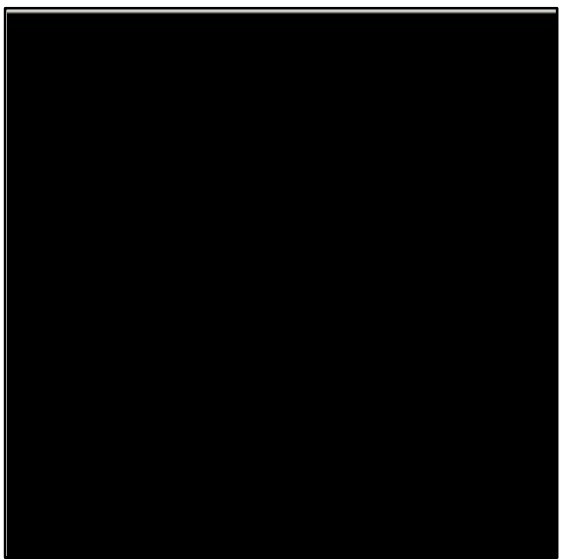

(b)

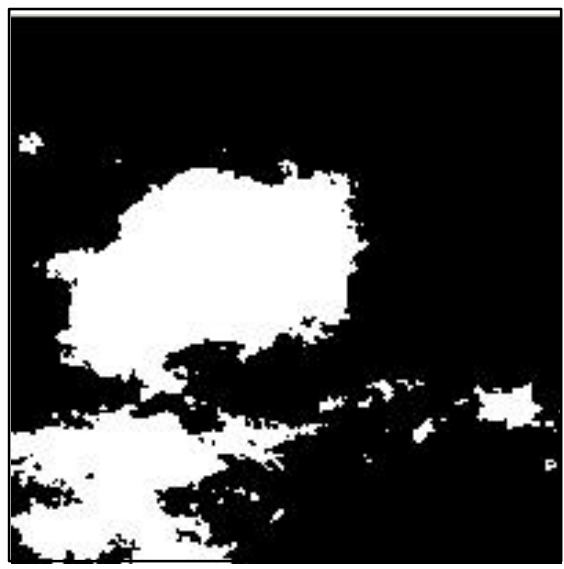

(d)

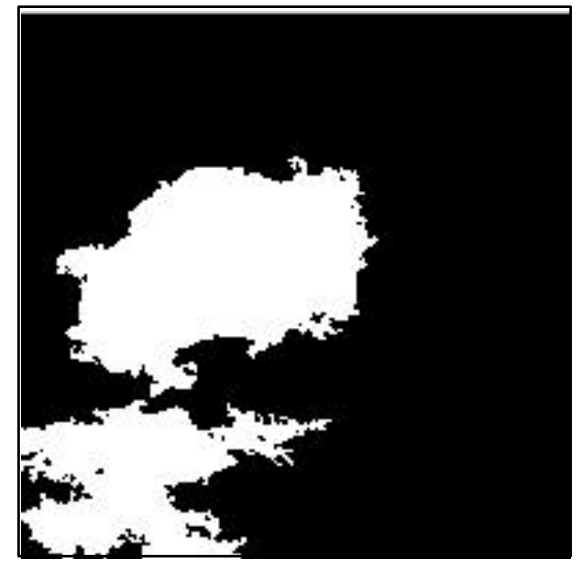

(e)

Figura 6-8 (a) Imagem Original; (b) Imagem Segmentada somente com Watershed; (c) Imagem Equalizada; (d) Imagem Segmentada com a combinação de ambas as técnicas e apresentação de ruídos; (e) Imagem final após rotulação. 


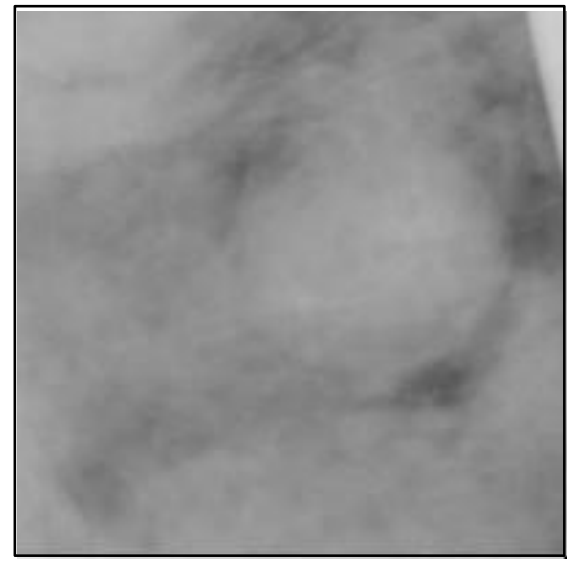

(a)

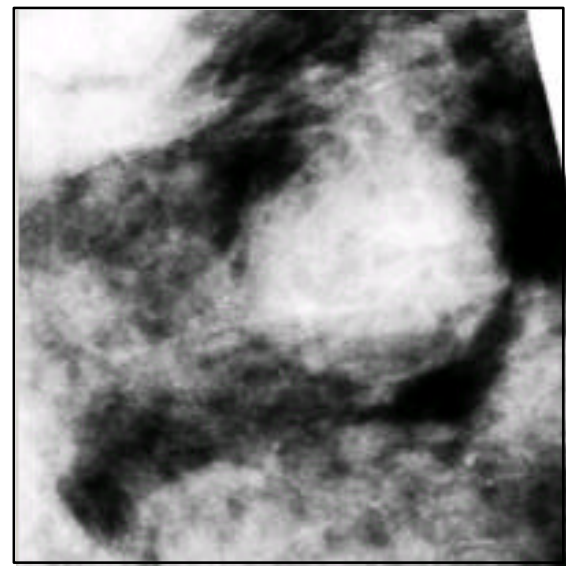

(c)

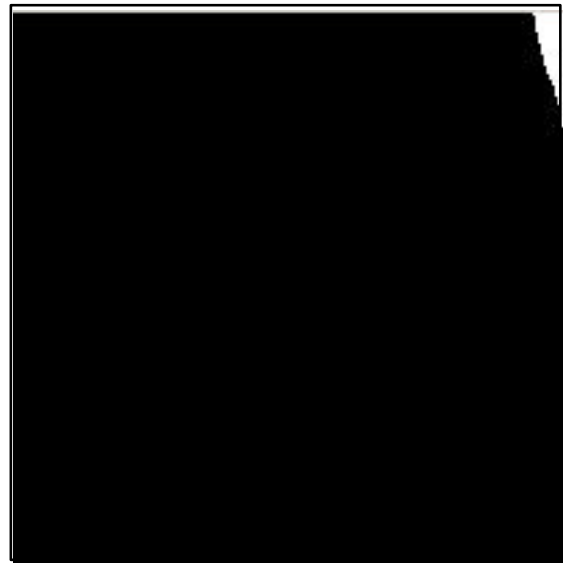

(b)

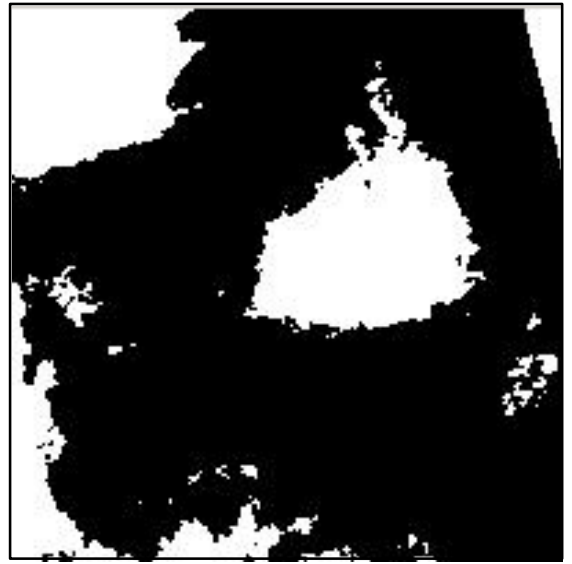

(d)

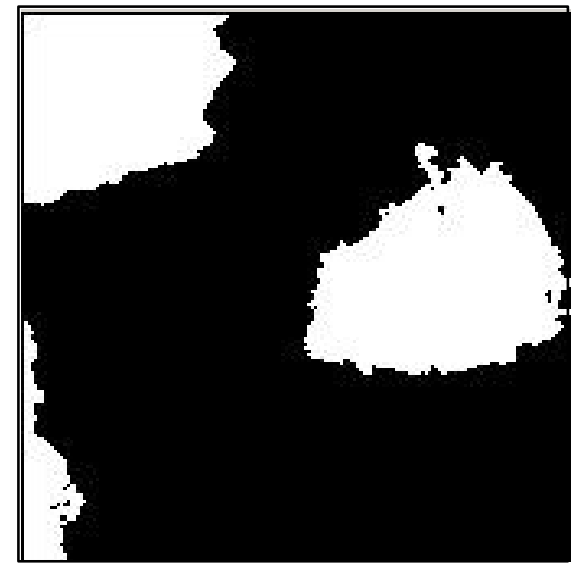

(e)

Figura 6-9 (a) Imagem Original; (b) Imagem Segmentada somente com Watershed; (c) Imagem Equalizada; (d) Imagem Segmentada com a combinação de ambas as técnicas e apresentação de ruídos; (e) Imagem final após rotulação. 


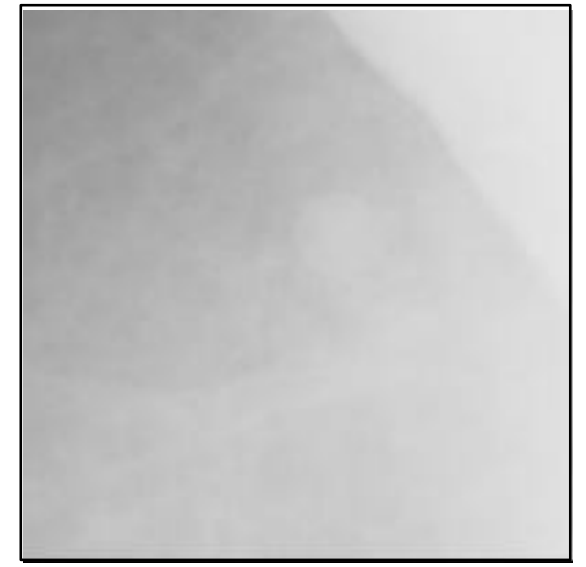

(a)

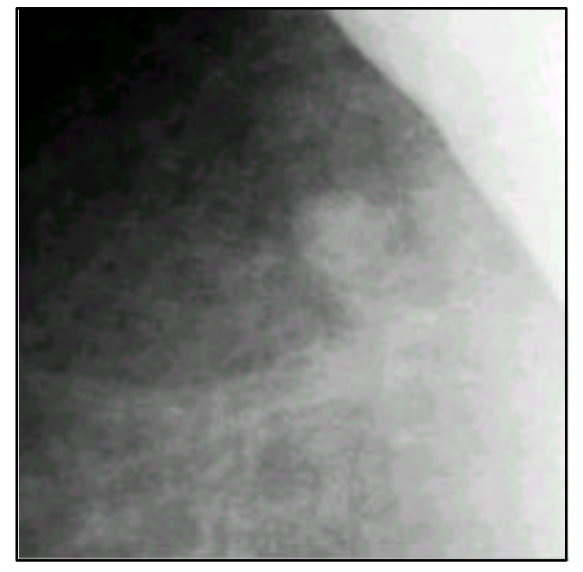

(c)

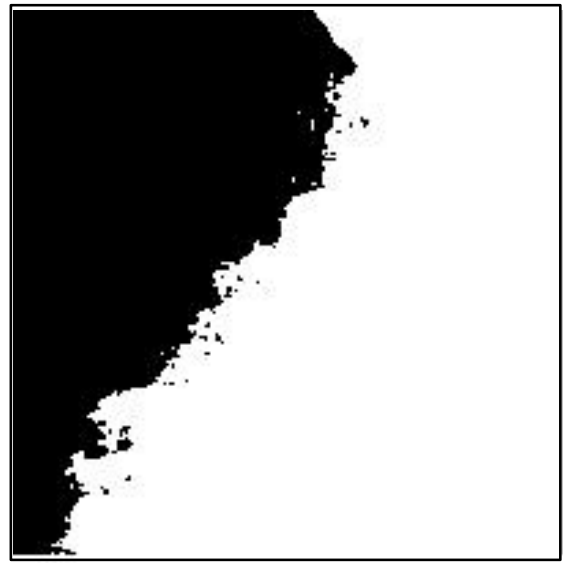

(b)

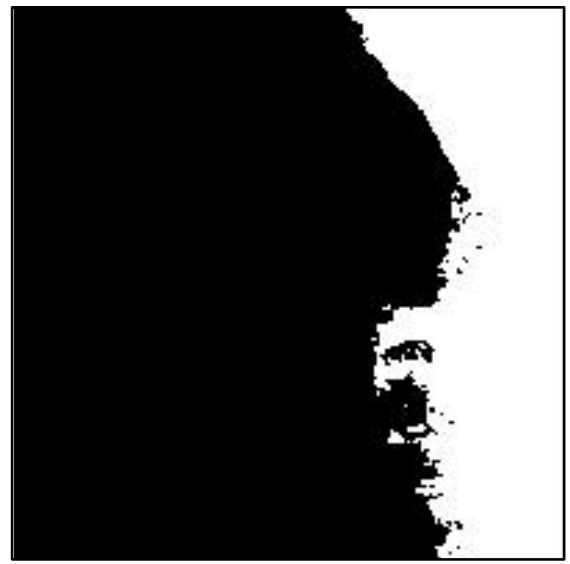

(d)

Figura 6-10 (a) Imagem Original; (b) Imagem Segmentada somente com Watershed, não apresentando detecção; (c) Imagem Equalizada; (d) Imagem Segmentada com a combinação de ambas as técnicas não apresentando detecção, sendo um falso-negativo. 


\section{Discussões e Conclusões}

Considerando que as imagens de mamas densas, características principalmente de mulheres jovens, constituem um desafio para os esquemas CAD devido ao baixo contraste entre as estruturas de interesse e os demais tecidos representados na mama e que, por isso, a detecção precoce do câncer de mama nesse grupo de mulheres fica prejudicada, a principal contribuição da pesquisa é a possibilidade do aumento de contraste em tais imagens e a segmentação para que as estruturas possam ser classificadas de ac ordo com as suas características.

Para esse trabalho foram estudadas técnicas de processamento de imagens utilizando a transformada Watershed para segmentar nódulos, gerando imagens para o processo de classificação que visa separar os nódulos encontrados em três principais categorias distintas: circular, lobular e espiculado.

As imagens submetidas ao processamento com a técnica desenvolvida foram comparadas com relação à quantidade de casos verdadeiros -positivos (VP) e falsos-positivos (FP) resultantes para o conjunto de regiões de interesse. $O$ diagnóstico verdadeiro-positivo acontece quando o sistema identifica e detecta um nódulo e realmente ele existe e o diagnóstico falso-positivo é quando o sistema aponta um nódulo na imagem, mas na verdade a região processada era de um mamograma normal. Os números de VP e FP foram obtidos analisando as informações contidas nos laudos radiológicos que acompanham as imagens mamográficas.

Nos parágrafos seguintes são avaliados os resultados obtidos com o conjunto de imagens a fim de fornecer um maior embasamento para as conclusões. 


\subsection{Desempenho do Sistema Desenvolvido}

No intuito de comparar os resultados das imagens processadas, serão apresentas as curvas ROC ( Receiver Operating Characteristic) dos resultados obtidos modificando o valor do marcador da imagem, obtidas através do software Origin 6.0 da Microcalc.

O método é definido por Evans (Evans, 1981) como um procedimento estatístico que leva em conta o aspecto subjetivo envolvido em um determinado evento. Esse método considera as discrepâncias e diferenças obtidas no resultado final de um experimento quando é computado o fator de incerteza introduzido por uma das etapas do processo. Seu objetivo é permitir a avaliação do desempenho de um evento, através da apresentação da relação percentual de acertos $\mathrm{X}$ percentual de erros. As curvas ROC tornaramse parâmetro obrigatório na avaliação de observadores e sistemas, especialmente na avaliação de esquemas $C A D$, devido ao seu caráter gráfico, que muitas vezes pode trazer mais informações qualitativas para a análise final do que a quantidade de informações que eventualmente poderiam ser extraídas através de tabelas e índices.

O traçado da curva ROC é feito levando-se em conta as probabilidades de ocorrência de VP em função da probabilidade de ocorrência de FP para cada ponto de operação anotado na curva, escolhido através de um critério pré-determinado. O principal parâmetro utilizado para comparação de desempenho entre duas curvas é a sua área. Essa área pode ser interpre tada como a capacidade do sistema em prever a saída, e por isso é utilizada como medida de eficiência do sistema que está sendo testado. Á área sob a curva é calculada por:

$$
A_{Z}=V P . P+V N . N
$$

onde:

$$
\begin{aligned}
& A_{Z}=\text { área sob a curva; } \\
& V P=\text { porcentagem de resultados verdadeiros -positivos; }
\end{aligned}
$$




$$
\begin{aligned}
& P=\text { porcentagem de casos positivos; } \\
& V N=\text { porcentagem de resultados verdadeiros- } \\
& \text { negativos; } \\
& N=\text { porcentagem de casos negativos. }
\end{aligned}
$$

Através da equação acima é possível perceber que quanto m ais o valor da área sob a curva $(A z)$ se aproximar da unidade, melhor será o comportamento do sistema. Isso significa que o sistema avaliado tem grande percentual de acertos (VP) com um baixo índice de falsas detecções, sendo um sistema de alta sensibilidade, que é uma situação sempre desejável.

No presente trabalho, o critério que foi variado para a construção das curvas ROC foi o valor do threshold do marcador, utilizando 4 valores para processar todas as imagens, tanto com nódulos como sem, originais e equalizadas. A seguir são apresentados os valores na Tabela 7-1 e o gráfico da curva na Figura 7-1.

Tabela 7-1 - Resultados obtidos com o processamento das imagens

\begin{tabular}{|l|l|l|}
\hline Valores de Threshold & \multicolumn{1}{|c|}{ VP $(y)$} & \multicolumn{1}{|c|}{ FP $(x)$} \\
\hline 1500 & 0,18 & 0,09 \\
\hline 2500 & 0,51 & 0,09 \\
\hline 3160 & 0,93 & 0,10 \\
\hline 3700 & 0,95 & 0,25 \\
\hline \multicolumn{2}{|l|}{ O valor da área da curva (AZ), foi igual a 0,91. } \\
\hline
\end{tabular}




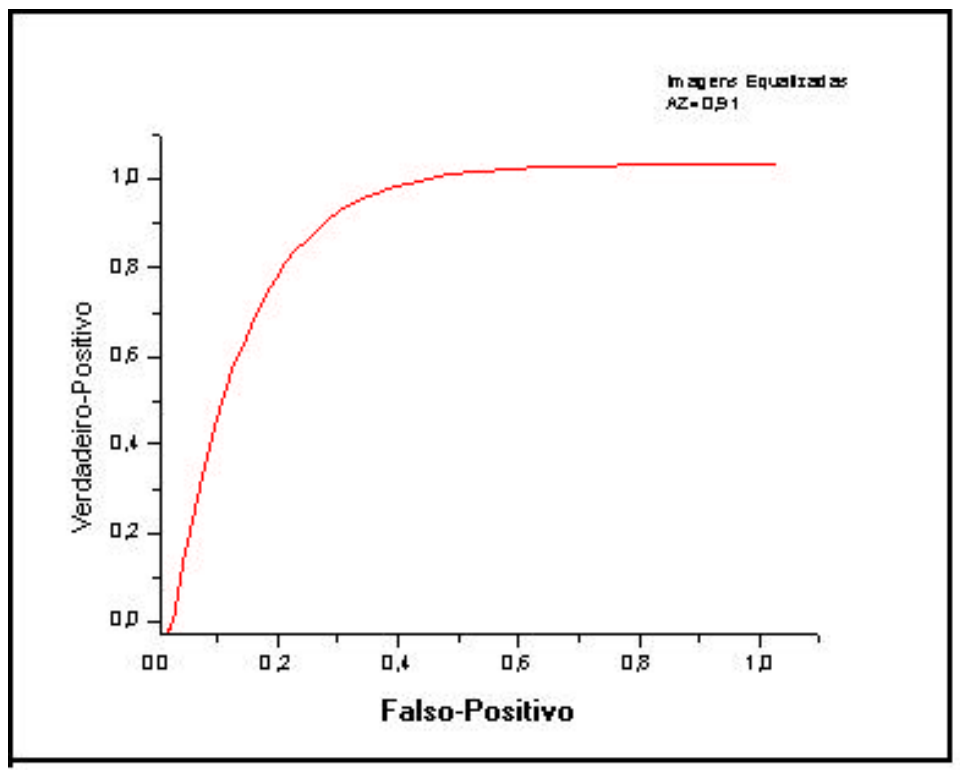

Figura 7-1 Curva ROC das Imagens Processadas

A curva ROC traçada na Figura 7-1 mostra os resultados obtidos com o processamento completo das imagens, incluindo o pré-processamento. Temos Az igual a 0,91. Como a área desta curva se aproxima bastante do valor 1, podemos dizer que o sistema tem um bom desempenho na detecção dos nódulos neste tipo de imagem, com o valor de threshold igual a 3160. Este valor foi selecionado baseado no histograma da imagem e a variação escolhida aleatoriamente para efeito de comparação e alterada manualmente no sistema. Este é um aspecto a ser questionado e aperfeiçoado para um ajuste automático do valor de threshold, dependendo da imagem a ser processada, num futuro desenvolvimento do presente esquema.

Cabe ressaltar que a transformada Watershed vem sendo amplamente utilizada para o processamento de diversos tipos de imagens tais como segmentação e contagem de imagens de células (Caetano, 1999); segmentação de imagens de estradas com o intuito de aplicar a um carro (Beucher, 1982). No entanto, para cada tipo de imagem, o tipo de marcador é modificado, segundo as características do problema a ser resolvido. 
Como o conjunto de imagens trabalhadas apresenta as mesmas características, foi possível deduzir que os nódulos detectados, em todas elas, apresentam níveis de cinza próximos e diferentes do restante da imagem, mesmo em se tratando de mamogramas de mamas densas. Para este conjunto de imagens pudemos observar que a densidade dos nódulos detectados varia muito pouco. No entanto, não podemos generalizar para qualquer tipo de mamograma. Neste caso, teríamos que analisar um conjunto com um número maior de casos.

Os resultados obtidos demonstram a eficácia da técnica de equalização do histograma combinada com a Transformada Watershed, já que obtivemos aproximadamente $93 \%$ de acerto na detecção dos nódulos nas imagens processadas onde o laudo do radiologista comprovava sua presença. Já quando foi aplicado apenas o processamento com a Transformada Watershed, o índice de acerto foi muito menor nas mesmas imagens.

As técnicas implementadas mostraram ser eficientes se combinadas, $\mathrm{e}$ de baixo custo computacional.

Mesmo com uma boa taxa de detecção, ainda temos um nível de cerca de $6 \%$ de falsos-negativos. Isso não deixa de ser preocupante, já que para esses casos, o nódulo existente na mama da paciente deixou de ser detectado pelo processamento. Isso se deve principalmente ao fato de que estamos lidando com imagens de mamas densas, cujos problemas de contraste são dificuldades explícitas até mesmo para os especialistas da área médica. No entanto, outras técnicas deverão ser agregadas ao sistema a fim de zerar estas taxas no futuro.

\subsection{Conclusões}

Para chegarmos às conclusões do trabalho, foram analisadas várias técnicas de segmentação de imagens até chegarmos à Transformada Watershed, que demonstrou bons resultados em imagens com características 
semelhantes às analisadas no trabalho. No entanto, os resultados preliminares obtidos não foram satisfatórios, apresentando uma alta taxa de falso-negativo.

Ao analisar estes resultados, concluiu-se que o pré-processamento para aumentar o contraste entre as estruturas presentes na imagem seria uma solução para aumentar as taxas de detecção. Então, implementou-se a equalização do histograma e os ganhos na detecção foram notáveis. Porém, isso aumentou também os ruídos presentes nas imagens processadas, o que levou à necessidade de aplicação de uma técnica de pós-processamento, no caso usou-se a rotulação para reduzir os mesmos e destacar os nódulos do restante da região de interesse, concluindo o processamento das imagens.

Muitas dificuldades foram encontradas, principalmente pela diversidade de algoritmos possíveis de implementação da transformada Watershed e também na escolha do melhor marcador da transformada.

Os índices de acerto (segundo as tabelas do capítulo 6), ficaram dentro de faixas consideradas satisfatórias pela maioria dos trabalhos da literatura, fato bem comprovado inclusive pela avaliação com as curvas ROC mostradas neste capítulo.

Sendo assim, o sistema desenvolvido pode-se constituir numa ferramenta na detecção de estruturas nodulares em imagens mamográficas de mamas densas e auxiliar no desempenho de esquemas CAD voltados à mamografia.

\subsection{Sugestões para Trabalhos Futuros}

Com as técnicas apresentadas nos capítulos anteriores obtivemos bons resultados. No entanto, ainda temos várias propostas e técnicas a serem implementadas, como trabalhos futuros:

$\Rightarrow$ A segmentação de imagens utilizando características texturais;

$\Rightarrow$ Implementação e testes de algoritmos hierárquicos da transformada Watershed; 
$\Rightarrow$ Estudo comparativo do processamento de imagens adquiridas por mamografias, ultra-som e ressonância magnética de mama, aplicando a técnica implementada com alterações para cada tipo de imagem.

$\Rightarrow$ Após o processamento do mamograma completo, descrever a posição do nódulo com relação aos quadrantes da mama, bem como sua disposição com relação à pele (contorno) da mama, já que para os radiologistas isso é muito importante para caracterizar e classificar o nódulo.

Vale lembrar que os sistemas computadorizados objetivam auxiliar na redução do número de falsos negativos e melhorar a interpretação das imagens. Porém, em todos os casos, a decisão do diagnóstico final e recomendação do tratamento apropriado é da equipe clínica. 


\section{Referências Bibliográficas}

[BAKER, 1982]

BAKER, L. H: The Breast Cancer Demonstration Project: five-year summary report. CA 32(4): 194-198, 1982

[BASSET, 1993]

BASSET, L. W., Hirbawi I.A, DeBruhl N, Hayes MK. Mammographyc positioning: evaluation from the view box. Radiology 1993; 188: 803806

[BAUER, 1980]

BAUER, W.; IGOT, J.P.; LE, G.Y.: Chronologic du cancer mammaire Utilisant un Modele de Croissance de Gompertz. Ann Anat Pathol 25:39-56, 1980

[BENATTI-2001]

BENATTI, R. H.; SCHIABEL, H.; NUNES, F. L. S.

Construção de uma base de mamogramas digitalizados para utilização em sistema de diagnóstico auxiliado por computador. In: XXIV Encontro Nacional de Física da Matéria Condensada, São Lourenço - MG, 2001. Anais. p.30, 2001. 
[BEUCHER, LANTUEJOUL, 1979]

S. Beucher and C. Lantuéjoul, Use of Watersheds in contour detection, In Proc. International Workshop on Image Processing, Real-Time Edge and Motion Detection/Estimation, Rennes (1979).

[BEUCHER;MEYER-1982]

Beucher, S.; Meyer, F. (1982). Image Analysis and mathematical Morphology - vol1, London Academic Press. Chapter 12-p:433-481

[BLAND;COPELAND -1994]

BLAND, K.I.; COPELAND, E.M. (1994) - A Mama: Tratamento Compreensivo das Doenças Benignas e Malignas, Ed., Manole Ltda

[BOYD-1995]

BOYD, N.F.; BYNG, J.W.; JONG, R.A.; FISHELL, E.K.; LITTLE, L.E.; MILLER, A.B.; LOCKWOOD, G.A.; TRITCHLER, D.L.; YAFFE, M.J. Quantitative classification of mammographic densities and breast cancer risk: results from the canadian national breast screening study. Journal of the National Cancer Institute, v. 87, p. 670-675, 1995.

[BYNG-1998]

BYNG, J. W.; YAFFE, M. J.; JONG, R.A.; SHUMAK, R.S.; LOCKWOOD, G.A.; TRITCHLER, R.S.; BOYD, N. F. Analysis of mammographic density and breast cancer risk from digitized mammograms. Radiographics, v.18, p.1587-1598, 1998. 
[CAVERSAN-2000]

CAVERSAN, F. L. Segmentação de Imagens

www.facens.Br/site/ensino/projetos/fabio/index.htm (24 Jul/2000)

[COLLETTE, 1984]

COLLETTE, H.J.A; DAY, N.E.; ROMBACH, J.J. DEWARD, F.: Evaluation of Screening for Breast Cancer in a Non-Randomised Study by Means os a Case Control Study. Lancet I:1224-1226. 1984.

[COSTA-2000]

COSTA, L.F.; CESAR, R.M. (2000) - Shape Analysis and Classification: Theory and Practice, Ed., CRC Press

[DIGABEL, LANTUÉJOUL, 1978]

H. Digabel and C. Lantuéjoul, Iterative algorithms, In Actes du Second Symposium Européen d'Analyse Quantitative des Microstructures en Sciences des Matériaux, Biologie et Médecine, Caen (1978), 85-99.

[DOl-1997]

DOI, K; GIGER, M.L.; NISHIKAWA, R.M.; SCHMIDT, R.A. Computer-aided diagnosis of breast cancer on mammograms. Breast Cancer, v.4, n.3, p.228-233, 1997.

[DOUGHERTY-1993]

DOUGHERTY, E.R. (1993). Mathematical Morphology in Image Processing, New York Marcel Dekker 
[EGAN-1980]

EGAN, R.L.; McSWEENEY, M.B.; SEWELL, C.W. Intramammary calcifications without an associated mass in benign and malignant diseases. Radiology, v.137, n.1, p.1-7, 1980.

[EKLUNG, 1994]

EKLUNG G.W., Cardernosa G., Parsons W. Assessing adequacy of mammographic image quality. Radiology 1994; 190: 227-307.

[ESCARPINATH2001]

ESCARPINATI, M.C.; Schiabel, H., GÓES, C.E. Nunes, F. L. S.; PATROCÍNIO, A.C.; Programa computacional para a interpretação e armazenamento de mamogramas digitalizados em formato TIFF com 12 bits. In: XXIV Encontro Nacional de Física da Matéria Condensada, São Lourenço - MG, 2001. Anais. p.30, 2001.

[EVANS-1981]

EVANS, A.L. The evaluation of medical images. Adam Hilger Ltd, Bristol, Great Britain, 1981.

[FACON, 1993]

Jacques Facon, Processamento e análise de imagens, 1993.

Jos B.T.M. Roerdink and Arnold Meijster, The Watershed transform: Definitions, algorithms and parallelization strategies, Fundamenta Informaticae 41 (2000), 187-228. 
[FEIG, 1988]

FEIG, S.A: Decreased Breast Cancer Mortality Though Mammographic Screening: Results of Clinical Trials. Radiology 167:659-665, 1988

[FISHER, 1981]

FISHER, E.R.: Relationship of Fibrocystic Discase With Cancer of the Breast in Breast Cancer. Breast Cancer CRC 120-135, 1981

[GIGER-2000]

GIGER, M.L. Computer-aided diagnosis of breast lesions in medical images. Computing in Science \& Engineering, v.2, n.5, p. 39-45,2000.

[GONZALES-1992]

GONZALEZ, R.C.; WOODS, R.E. (1992) - Digital Image Processing, 3rd. Ed., Addison- Wesley

[GUPTA]

GUPTA, R.; UNDRILL, P.E.

"The use of texture analysis to identify suspicious masses in mammography" Department of Bio-Medical Physics \& BioEngineering, University of Aberdeen, Foresterhill, Aberdeen, AB9 2ZD.

[KOBAYASHI, 1996]

KOBAYASHI, T.; DOI, K.; XU, X.;MACMAHON, H. METZ, C.E. - Effect of a Computer-Aided Diagnosis Scheme on Radiologists'Performance in Detection of Lung Nodules on Radiographs. Radiology 1996; 199:843848. 
[KUPINSKI, 1998]

KUPINSKI, M.A; GIGER, M.L. - Automated Seeded Lesion Segmentation on Digital Mammograms. IEEE Transaction On Medical Imaging, Vol 17 № $04-$ Agosto/1998

[MARQUES, 1992]

MARQUES, O.; VIEIRA, H. Processamento Digital de Imagens (1992), Ed., Brasport Livros e Multimídia Ltda

[MITCHELL-1998]

MITCHELL JR., G.W.

Mastologia Prática. Revinter, 1988.

USPAR - Centro de Diagnósticos

[NIKHIL - 1993]

NIKHIL R. PAL; SANKAR K. PAL

"A Review on Image Segmentation Techniques." Machine Intelligence Unit. Indian Statistical Institute, 203 B.T. Road. Calcuta 700 035. India (received for publication 3 March 1993)

[NISHIKAWA1993]

NISHIKAWA, R. M.; GIGER, M. L.; DOI, K.; VYBORNY, C. J.; SCHMIDT,R.A.

"Computer-Aieded Detection ans Diagnosis of masses and clustered microcalcifications from digital mammograms" Published in: State of the art in digital Mammographic Image Analysis (1993) 
[NUNES-2001]

Nunes, F. L. S.; Schiabel, H.; Benatti, R. H.; Stamato, R.C.; Vieira, M.A.C. A technique to measure breast density in digitized mammograms. The 5 th World Multi-Conference on Systemics, Cybernetics and Informatics SCI 2001, Orlando, Florida USA, July 22-25, 2001c.

[PACIORNIK-2001]

PACIORNIK, S. (2001). Introdução ao Processamento Digital de Imagens http://www.dcmm.puc-rio.br/Cursos/IPDI/tsld116.htm (24 Jul/2001)

[PARKER-1994]

PARKER , J.R. (1994). Practical Computer Vision Using C, New York John Wiley

[PETRICK-2000]

PETRICK, N., SAHINER B., CHAN H.P., HELVIE, M.A., PAQUERAULT, S.; Preclinical Evaluation of a CAD Algorithm for Early Detection of Brest Cancer; 5o International Warkshop on Digital Mammography, 2000.

[RIVEST,SOILLE;1992]

RIVEST, J.F.; SOILLE, P.; BEUCHER,S. - Morphological Gradients, 1992 Centre de Morphologie Mathématique, Ecole des Mines de Paris, Fontainebleau, France

[SENA-1982]

SENA, J. (1982). Image Analysis and mathematical Morphology - vol1, London Academic Press. 
[SCHIABEL-1999]

SCHIABEL,H.; NUNES, F.L.S.; BENATTI, R.B. Um banco de imagens digitalizadas de mamas densas para teste de sistemas de diagnóstico auxiliado por computador. XXVIII Congresso Brasileiro de Radiologia, São Paulo-SP, 12 de outubro de 1999.

[VAN-1995]

VAN GILS, C.H.; OTTEN, J.D.; VERBEEK, A.L.M.; HENDRICKS, J.H.C.L. Short communication: breast parenchymal patterns and their changes with age. The British Journal of Radiology, v. 68, p. 1133-1135, 1995.

[VAN-1998]

VAN GILS, C.H.; OTTEN, J.D.M.; VERBEEK, A.L.M.; HENDRIKS, J.H.C.L.; HOLLAND, R. Effect of mammographic breast density on breast cancer screening performance: a study in Nijmegen, the Netherlands. J Epidemiol Community Health, v. 52, p.267-271, 1998.

[VIEIRA-2000]

VIEIRA, A. V. (2000). Centro de Medicina Nuclear da Guanabara http://www.hps.com.br/medicinanuclear/mamoalta.htm (08 Jan/2001)

[VINCENT, SOILLE, 1991]

L. Vincent and P. Soille, Watersheds in digital spaces: an eficient algorithm based on immersion simulations, IEEE Transactions on Pattern Analysis and Machine Intelligence 13 (1991), no. 6, 583-598. 
[YAFEE, 1995]

YAFFE, M. J., Herdrich, R.E., Feig, S.A., Rothenberg, L.N., Oeh, J., Gagne, R.: Recommended Specifications for New Mammography Equipament: Report of ACR-CDC Focus Group on Mammography Equipament. Radiology 197: 19;26, 1995

[YARUSSO-2000]

YARUSSO, L.M., NISHIKAWA, R.M., GIGER, M.L., PAPAIOANNOU, J., BAEHR, A.E., VENTA, L.A., NAGEL, R., KUPINSKI, M.A.; Aplication of Computer-Aided Diagnosis to Full-Field Digital Mammography; 50 International Warkshop on Digital Mammography, 2000.

\section{Sites Visitados:}

A Service of the National Cancer Institute (2000).

http://cancernet.nci.nih.gov/clinpdq/facts_span2/600528.html (05 Mar/2000)

Atenção Integral à Saúde da Mulher (1997/2001)

http://gineco.Com.Br/mamograf.htm (23 Jul/2000)

Brazilian Workshop'96 On Mathematical Morphology www.dca.Fee.Unicamp.Br/ lotufo/Courses/ia-8651996/mm_segm/html/c1/Watershed/front-page.html (21 Jan/2001)

Centro de Diagnóstico Dr Enrique Rossi

www.cdrossi.Com/servicios_al_paciente/mamografia/mamografia.htm

$(08$ Nov/2000) 
INCA - Instituto Nacional de Câncer/Ministério da Saúde. (1996-2002). Falando Sobre Doenças da Mama

http://www.inca.org.br/manual/mama/index.html (04 Out/2002)

Mamografia (1999)

www.sel.Eesc.Sc.Usp.Br/ladi/portal/mamografia.html (20 Ago/2000)

UNICAMP (1996)

www.dca.Fee.Unicamp.Br/ tatibana/AIRP/Welcome.html(20 Jan/2001)

VERLAB (Laboratório de Visão Computacional e Robótica).

http://www.verlab.dcc.ufmg.br/ (24 Jul/2001) 